\author{
UNIVERSIDADE DE SÃO PAULO \\ ESCOLA DE ENGENHARIA DE LORENA
}

SANDRA HELENA DA SILVA ROSA

Educação Ambiental Baseada em Projetos: Uma Aplicação no

Ensino Médio e Fundamental 



\section{Educação Ambiental Baseada em Projetos: Uma Aplicação no Ensino Médio e Fundamental}

Dissertação apresentada à Escola de Engenharia de Lorena da Universidade de São Paulo para obtenção do título de Mestre em Ciências do Programa de Mestrado Profissional em Projetos Educacionais de Ciências.

Orientador: Prof. Dr. Eduardo Ferro dos Santos

Edição reimpressa e corrigida

LORENA, SP

Dezembro, 2017 
AUTORIZO A REPRODUÇÃO E DIVULGAÇÃO TOTAL OU PARCIAL DESTE TRABALHO, POR QUALQUER MEIO CONVENCIONAL OU ELETRÔNICO, PARA FINS DE ESTUDO E PESQUISA, DESDE QUE CITADA A FONTE

Ficha catalográfica elaborada pelo Sistema Automatizado da Escola de Engenharia de Lorena, com os dados fornecidos pelo(a) autor(a)

Rosa, Sandra Helena da Silva

Educação Ambiental Baseada em Projetos: Uma Aplicação no Ensino Médio e Fundamental / Sandra Helena da Silva Rosa; orientador Eduardo Ferro dos Santos - ed. reimp., corr. - Lorena, 2017. $85 \mathrm{p}$.

Dissertação (Mestrado em Ciências - Programa de Mestrado Profissional em Projetos Educacionais de Ciências) - Escola de Engenharia de Lorena da Universidade de São Paulo. 2017

Orientador: Eduardo Ferro dos Santos

1. Aprendizagem baseada em projetos. 2 . Metodologias ativas de ensino aprendizagem. 3. Educação ambiental. I. Título. II. Santos, Eduardo Ferro dos, orient. 
Dedico esse trabalho a Deus, aos meus filhos Carlos Augusto e Carlos Eduardo, à minha família, aos meus amigos e alunos. 



\section{AGRADECIMENTOS}

À Deus por se fazer presente todos os dias na minha vida.

Ao meu marido e aos meus filhos Carlos Augusto e Carlos Eduardo pela paciência, incentivo e compreensão. Compartilho esse momento de felicidade com vocês. Minha vida! Meus amores!

Aos meus pais pelo carinho e incentivo.

Ao meu querido amigo Professor Doutor Eduardo Ferro dos Santos, pelas suas orientações valiosas, pela sua paciência, sabedoria, dedicação e por acreditar na minha capacidade para concluir esse trabalho. Muito obrigada e que Deus o abençoe.

Aos meus queridos alunos que aceitaram a participar da pesquisa com muita dedicação.

Ao Professor Doutor Marco Aurélio Alvarenga Monteiro e a Professora Doutora Maria Auxiliadora Barreto pelas críticas e sugestões valiosas dadas no exame de qualificação, para o enriquecimento dessa pesquisa.

Ao amigo Júlio Alberto Sales pelo incentivo, paciência e companheirismo.

Aos Professores do Programa de Pós Graduação em "Projetos Educacionais em Ciências" por partilhar seus conhecimentos.

À amiga e professora Marilena Alves Di Domenico pelo incentivo e tempo disponibilizado para revisar essa pesquisa.

À amiga Mara Lúcia da Silva Farias de Souza Santos que se fez presente nos momentos mais difíceis de minha vida.

A toda equipe da escola em que trabalho, pela dedicação e apoio. 

Nós somos aqueles por quem estávamos esperando. Nós somos a mudança que procuramos. 



\section{RESUMO}

ROSA, S. H. S. Educação ambiental baseada em projetos: uma aplicação no Ensino Médio e Fundamental. 2017. 85p. Dissertação (Mestrado em Ciências) - Escola de Engenharia de Lorena, Universidade de São Paulo, Lorena, 2017.

Atualmente percebe-se que é necessário romper com os paradigmas do ensino tradicional, que muitas vezes vê o aluno como um receptor de informações. É preciso adotar novas práticas pedagógicas, que despertem o interesse de aprendizagem nos alunos. Este trabalho apresenta uma aplicação da (ABP) Aprendizagem Baseada em Projetos, uma metodologia ativa de ensino aprendizagem, que estimula o desenvolvimento de competências e desafios, onde os alunos se envolvem com problemas reais da sociedade, buscando alternativas para o desenvolvimento de soluções. Alunos do Ensino Médio e Fundamental, de uma instituição pública de ensino, na cidade de Lorena/SP, são envolvidos na prática, buscando alternativas para o desenvolvimento de soluções. A aplicação da metodologia propôs a construção de uma solução para acabar com o desperdício de água, fazendo reuso desse recurso em ambiente escolar, integrando ao mesmo tempo em que o pesquisador, interage com os alunos. Desenvolvendo uma aprendizagem mais atraente e significativa. O método de pesquisa utilizado foi o de Pesquisa- ação, que utilizou de questionários estruturados e roteiros de observação. Ao mesmo tempo em que o pesquisador, interage com os alunos. Os resultados demonstraram que, a aplicação da ABP no ensino relacionado às áreas do saber: Física, Geografia, História, Arte, Língua Portuguesa e Matemática, permitiu grande envolvimento dos alunos ao trabalharem em grupos, respeitando opiniões diversas, gerando maior estímulo à criatividade na resolução de problemas reais e demonstrando indícios de argumentação científica. Permitiu também que as sugestões dos alunos fossem recebidas pela escola como projetos reais de aplicação, colaborando na redução de desperdícios hídricos e no consumo sustentável da instituição.

Palavras-chave: Aprendizagem Baseada em Projetos. Metodologias Ativas de Ensino Aprendizagem. Educação Ambiental. 


\begin{abstract}
ROSA, S. H. S. Environmental Education and Project Based Learning: An Application in the High and Elementary School. 2017. 85p. Dissertation (Master of Science) - Escola de Engenharia de Lorena, Universidade de São Paulo, Lorena, 2017.
\end{abstract}

Nowadays we realize that it is necessary to break with the paradigms of traditional education that see the student as a simple information receiver. It is necessary to adopt new pedagogical practices that arouse students' interest in learning. This paper presents an application of Project-Based Learning (ABP), an active learning teaching methodology, which stimulates the development of competencies and challenges, where students engage with real problems of society, seeking alternatives for developing solutions. High School and Elementary students from a public educational institution in the city of Lorena / SP, are involved in the practice, seeking alternatives for the development of solutions. The application of the methodology proposed the construction of a solution to end the waste and the excessive consumption of water in school environment. Reusing this resource, integrating the common disciplines in the levels of education, trying to stimulate students to face challenges in different situations, developing a more attractive and meaningful learning. The research method used was the action research, which used structured questionnaires and observation scripts. At the same time the researcher interacts with the students. The results showed that the application of PBL in teaching related to the areas of knowledge: Physics, Geography, History, Art, Portuguese Language and Mathematics allowed students to be involved in working in groups, respecting diverse opinions, generating greater creativity in solving real problems and showing evidence of scientific argument. It also allowed the students' suggestions to be received by the school as real implementation projects, collaborating in the reduction of water wastes and in the sustainable consumption of the institution.

Keywords: Project-Based Learning. Active Learning Methodologies Learning. Environmental education. 


\section{LISTA DE FIGURAS}

Figura 1 - Publicações (a) e citações (b) para o termo "Project-Based Learning” and “ K12"

Figura 2 - Publicações (a) e citações (b) para os termos "Project Based Learning" and “

High School" 30

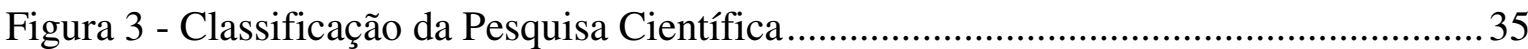

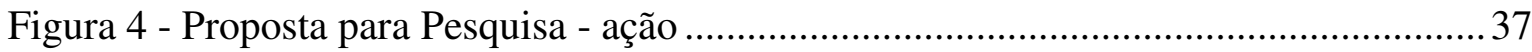

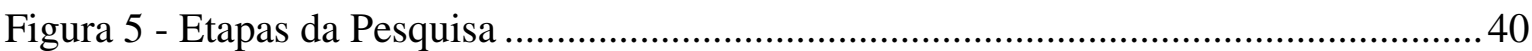

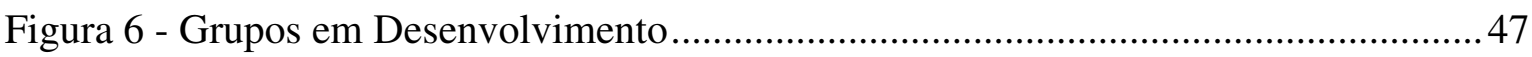

Figura 7 - Orientação dos Docentes aos Grupos............................................................. 47

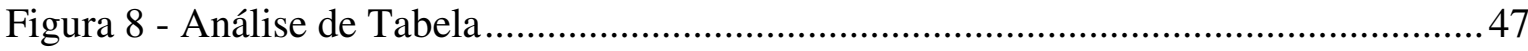

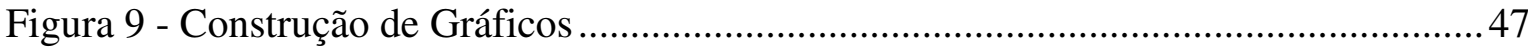

Figura 10 - Atividades na Sala de Informática ................................................................... 48

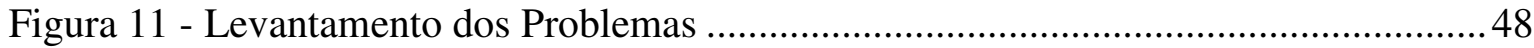

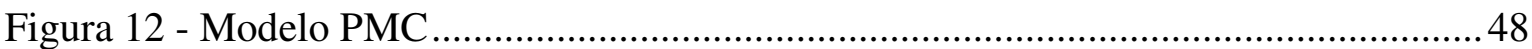

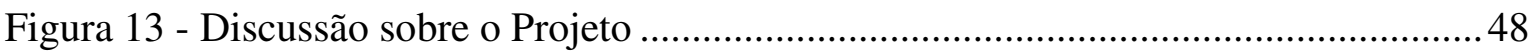

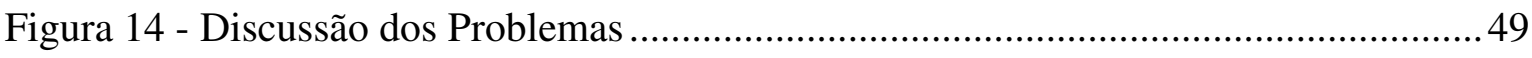

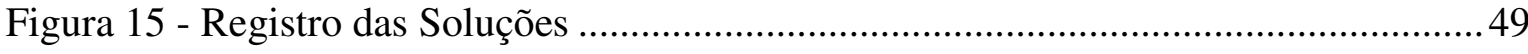

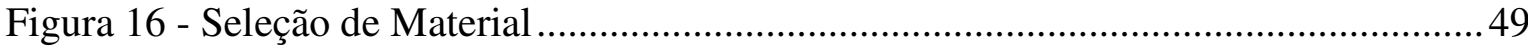

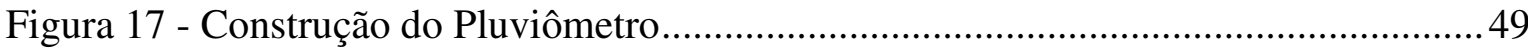

Figura 18 - Marcação de Escala de Medição …………...........................................................50

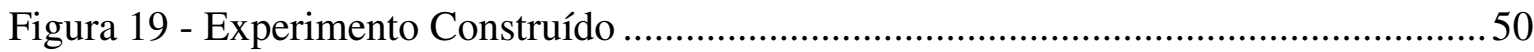

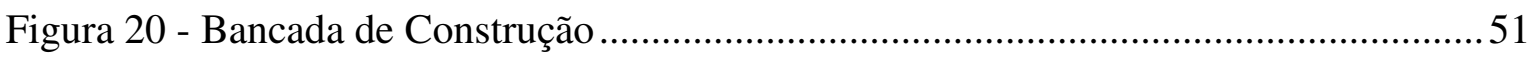

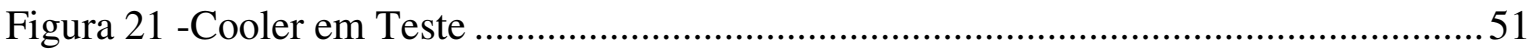

Figura 22 - Construção do Protótipo................................................................................ 51

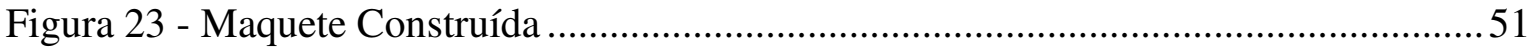

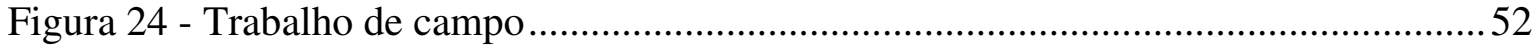

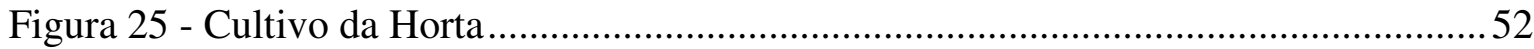

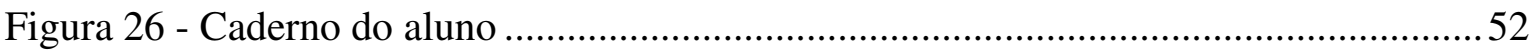

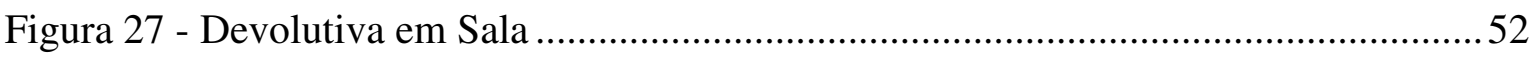

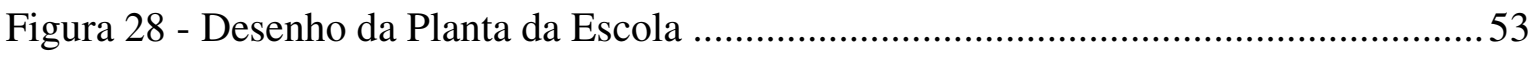

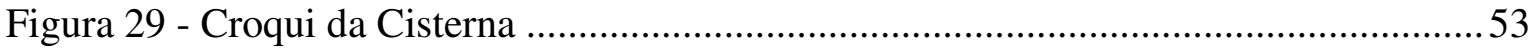

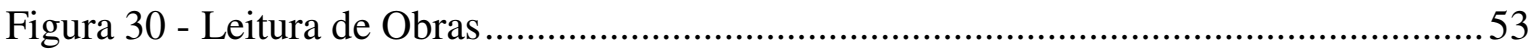




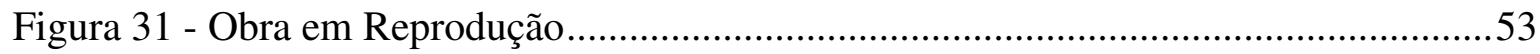

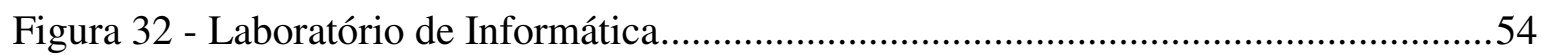

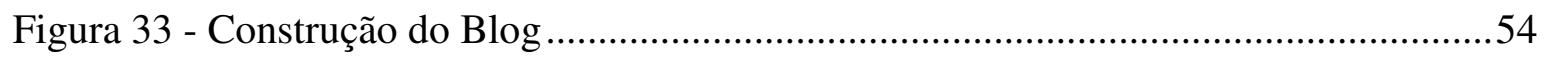

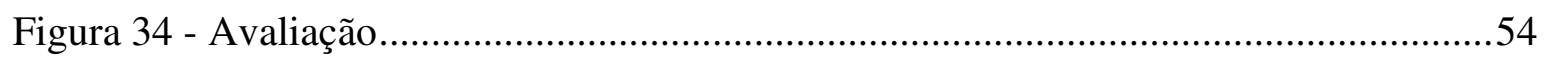

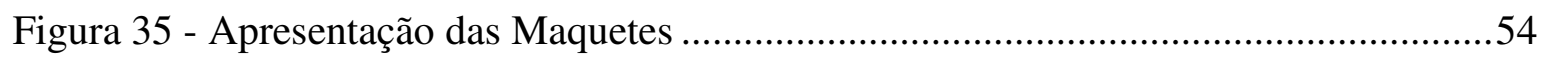

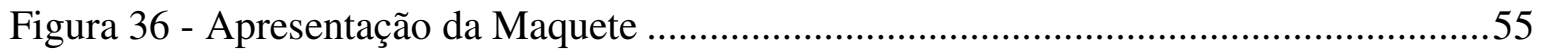

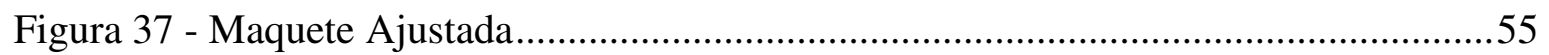

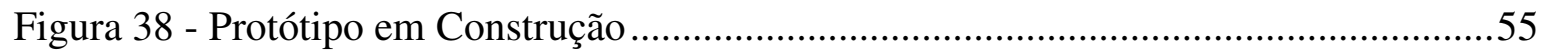

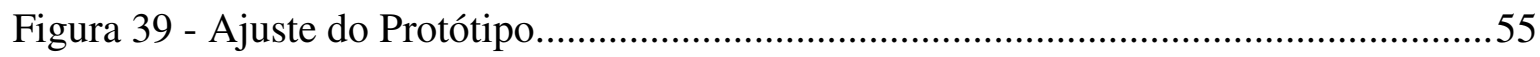

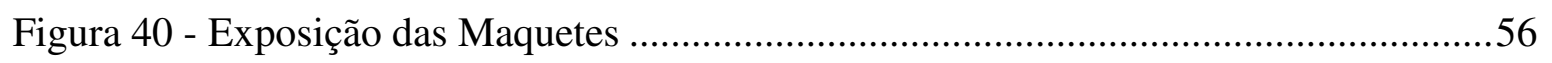

Figura 41 - Visitação na Feira de Ciências ......................................................................56

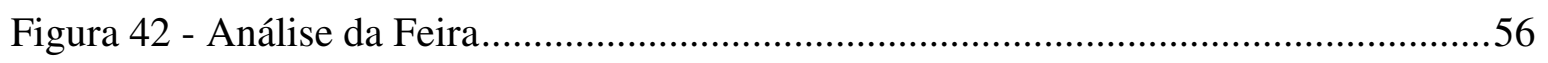

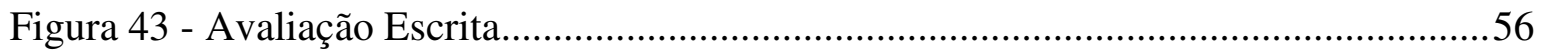

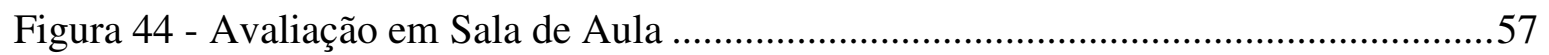

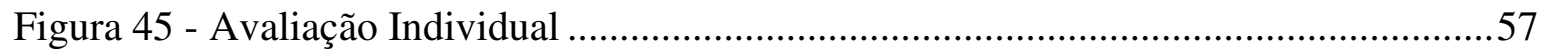

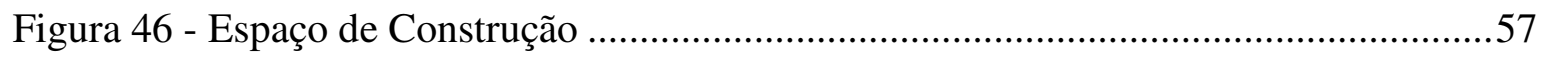

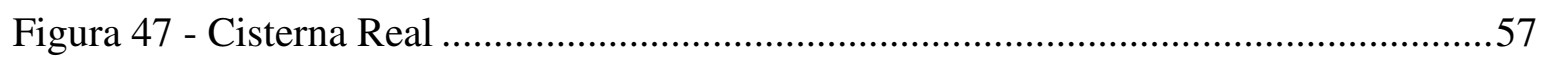

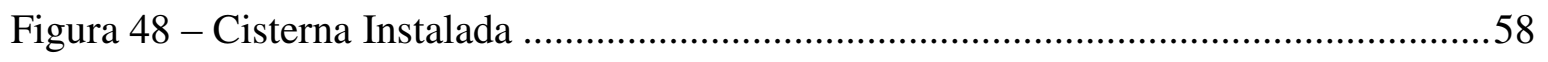

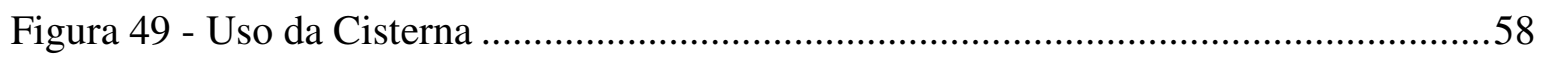

Figura 50 - Resposta dada pelo aluno a participante da pesquisa quanto ao aprendizado de

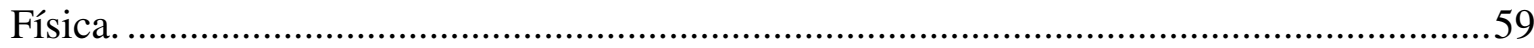

Figura 51 - Resposta dada por um aluno participante da pesquisa quanto ao aprendizado de Física.

Figura 52 - Resposta dada por um aluno participante da pesquisa quanto ao aprendizado de Geografia. 60

Figura 53 - Resposta dada por um aluno participante da pesquisa quanto ao aprendizado de Geografia. 60

Figura 54 - Resposta dada por um aluno participante da pesquisa quanto ao aprendizado de Matemática. 60

Figura 55 - Resposta dada por um aluno participante da pesquisa quanto ao aprendizado de Matemática......

Figura 56 - Resposta dada por um aluno participante da pesquisa quanto ao aprendizado de Arte.

Figura 57 - Resposta dada por um aluno participante da pesquisa quanto ao aprendizado de 
Arte.

Figura 58 - Resposta dada por aluno participante da pesquisa quanto à aprendizagem em relação à $\mathrm{ABP}$.

Figura 59 - Resposta dada por um aluno participante da pesquisa quanto à aprendizagem em relação à $\mathrm{ABP}$.

Figura 60 - Resposta dada pelo aluno X participante da pesquisa em relação a sua participação no Projeto.

Figura 61 - Resposta dada pelo aluno Y participante da pesquisa em relação a sua participação no Projeto.

Figura 62 - Resposta dada pelo aluno Z, participante da pesquisa em relação a sua participação no Projeto. 63

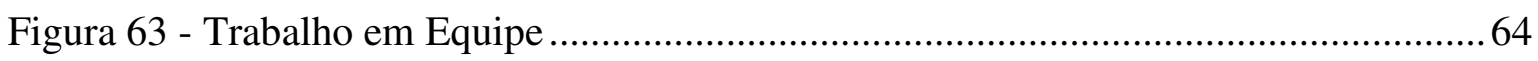

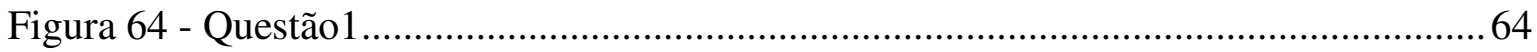

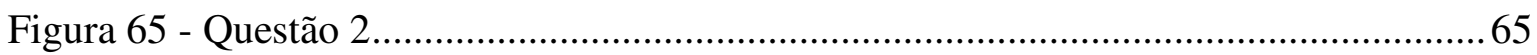

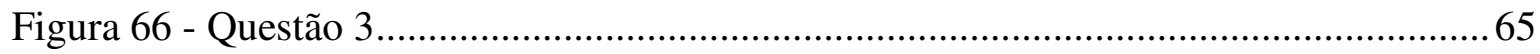

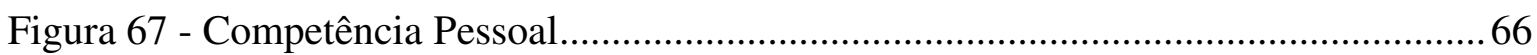

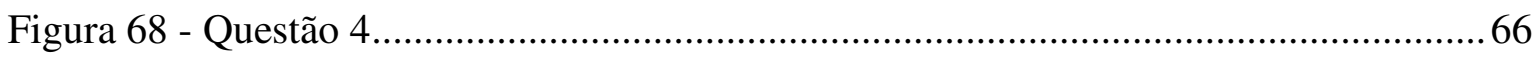

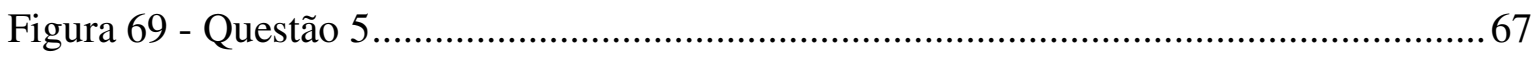

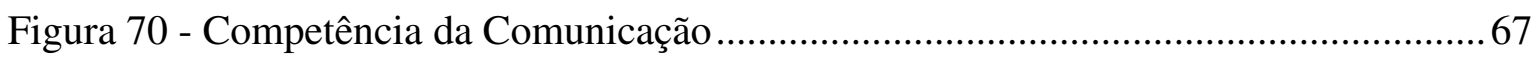

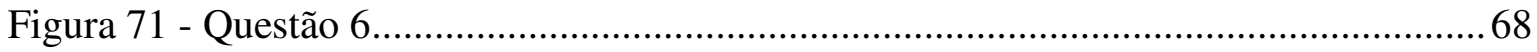

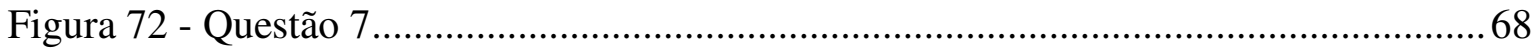

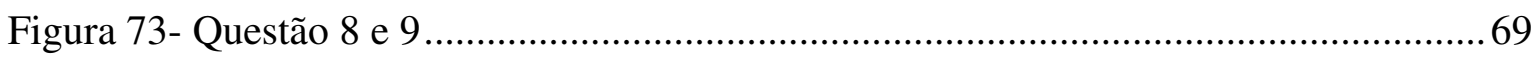

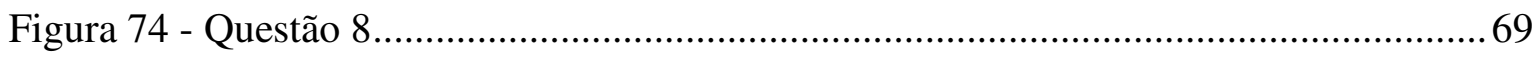

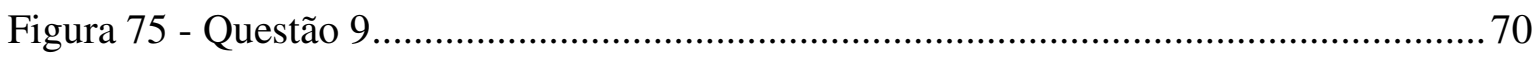

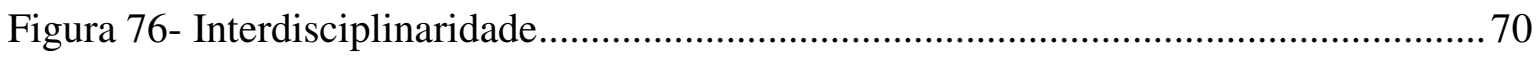

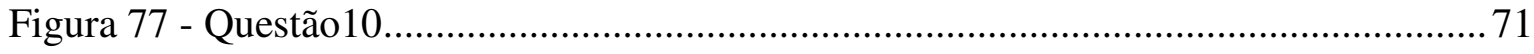

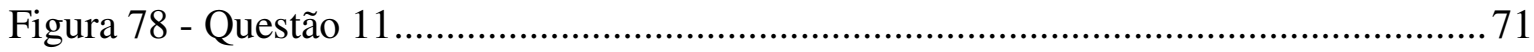

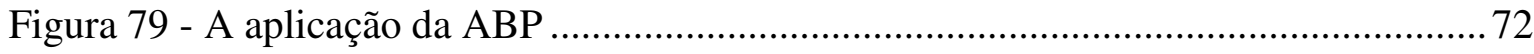

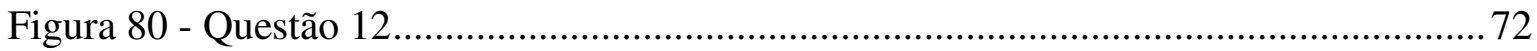

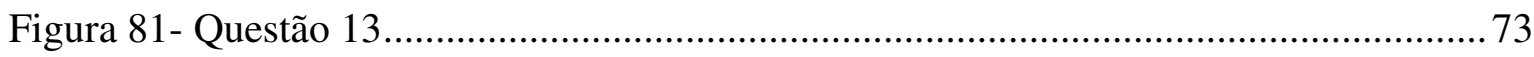

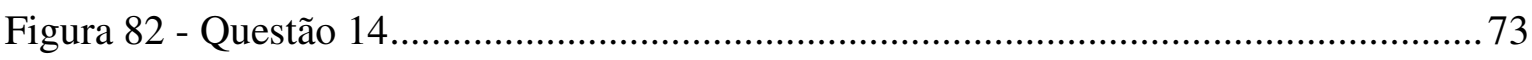

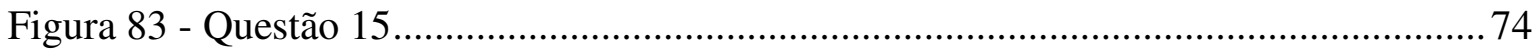




\section{LISTA DE QUADROS}

Quadro 1 - Comparativo entre a abordagem convencional do ensino e a ABP .25

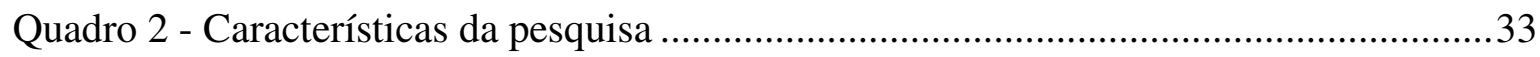

Quadro 3 - Relevância e argumentação ....................................................................... 38

Quadro 4 - Síntese da Metodologia de Pesquisa................................................................39

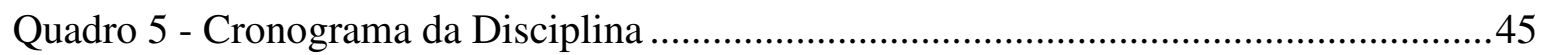




\section{SUMÁRIO}

1 INTRODUÇÃ

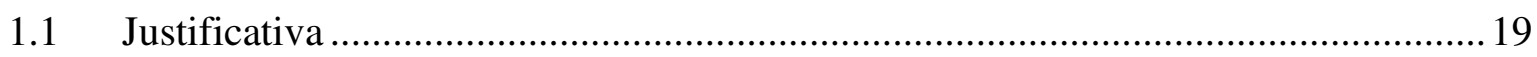

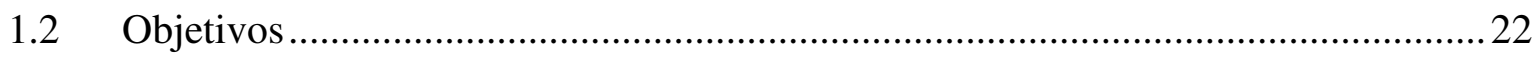

1.2.1 Objetivo Geral ................................................................................................22

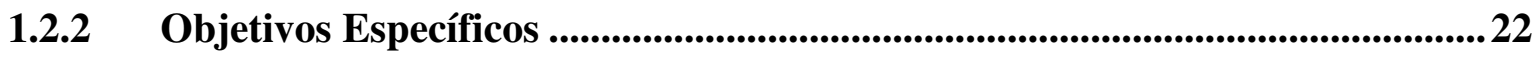

2 METODOLOGIAS ATIVAS E ENSINO DE CIÊNCIAS ..................................23

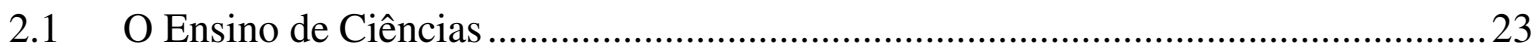

2.2 Aprendizagem Baseada em Projetos (ABP) ........................................................24

2.3 Processos de Avaliação do Ensino e Aprendizagem .............................................. 30

3 METODOLOGIA DA PESQUISA ...............................................................32

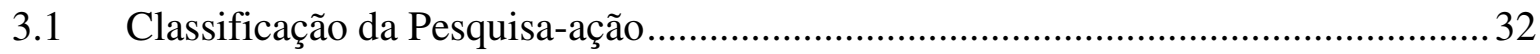

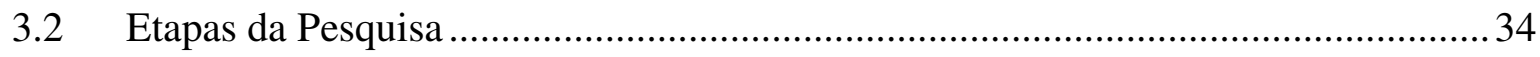

4 O MÉTODO APLICADO ............................................................................42

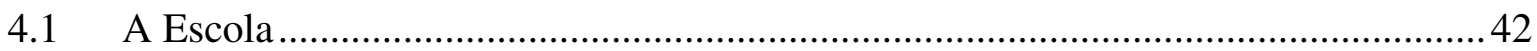

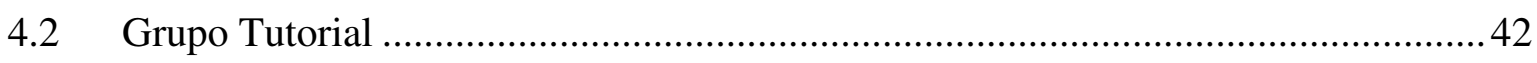

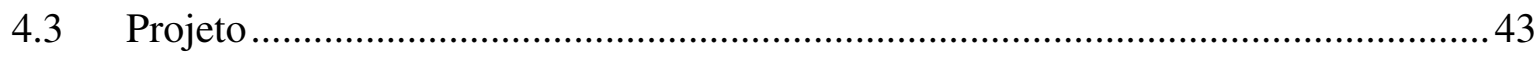

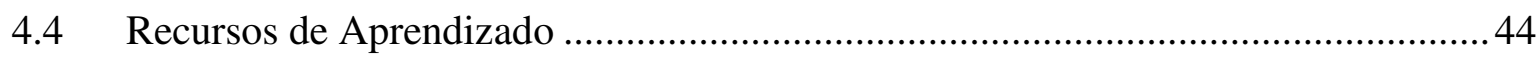

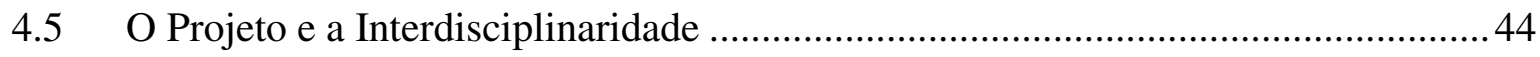

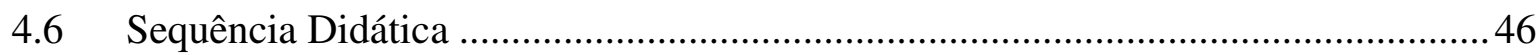

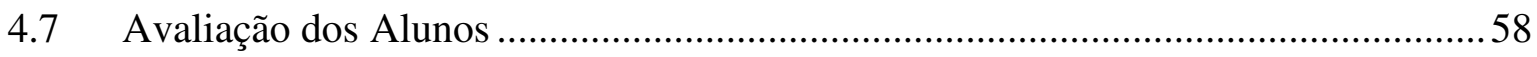

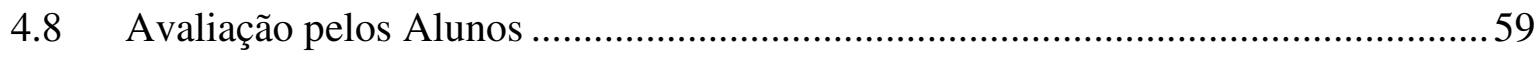

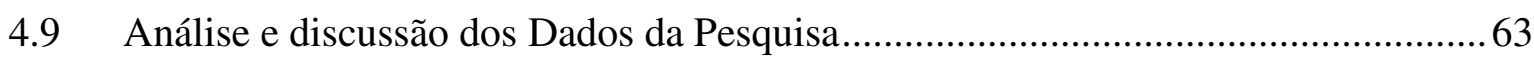

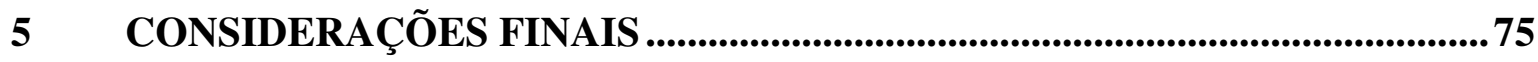

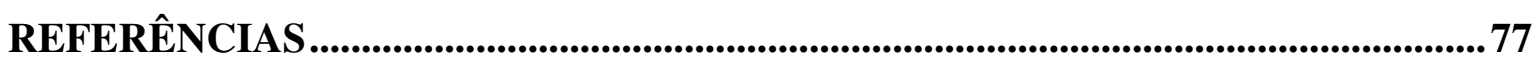

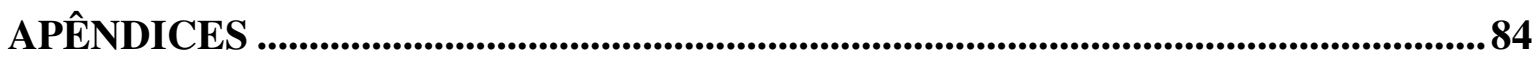





\section{INTRODUÇÃO}

Preparar o aluno para enfrentar os problemas e vencer desafios do dia a dia é uma preocupação constante na história da educação. O mercado de trabalho é uma grande preocupação para o ensino, pois o futuro trabalhador precisa ser criativo para produzir cada vez mais e melhor. O jovem no ensino precisa aprender habilidades para enfrentar problemas. O bom profissional atua de forma crítica, com maturidade buscando soluções diversas para qualquer situação problema que aconteça (TREVELIN; PEREIRA; OLIVEIRA NETO, 2010).

Percebe-se a cada dia, a necessidade de um educador que promova o conhecimento cognitivo e desenvolva competências e habilidades em um trabalho interdisciplinar, abordando conteúdos curriculares de forma dialogada e participativa. Araújo (2014) resume esta situação como uma necessidade de reinventar a educação, tendo em vista que o modelo tradicional de escola consolidado no século XIX, tem que dar conta das demandas e necessidades de uma sociedade mais democrática e inclusiva, permeada pelas diferenças e pautada no conhecimento inter, multi e transdisciplinar. Desta maneira, Hernandez e Montserrat (1998) afirmam que é necessário redefinir os espaços de aprendizagem de tal forma que eles se voltem para a formação de sujeitos ativos, reflexivos, atuantes e participantes, onde as decisões e controle do projeto devem ficar especialmente com o professor, enquanto os alunos ficam responsáveis por desenvolverem o projeto em busca de conhecimento, por meio de tarefas distribuídas nas atividades que deverão empenhar.

De acordo com Masson et al. (2012), John Dewey (1859 - 1952) foi um filósofo americano que a partir de 1900 comprovou o "aprender mediante o fazer", valorizando, questionando e contextualizando a capacidade de pensar dos alunos numa forma gradativa de aquisição de um conhecimento para resolver situações reais. Dewey e Bruner foram responsáveis por desenvolver os conceitos fundamentais e a formulação da Aprendizagem Baseada em Projetos, que até hoje apresenta uma visão de aprendizagem motivadora no processo de ensino aprendizagem. Segundo Dewey (1959 apud MASSON, 2012) o conhecimento é construído por meio de questionamentos, troca de ideias e discussões em grupo. Os alunos devem compartilhar suas ideias, questionar a realidade e aplicar a teoria em problemas reais, despertando o interesse nos mesmos para experimentar e pensar por si próprio construindo o conhecimento.

A Aprendizagem Baseada em Projetos (ABP), ou do inglês Project Based Learning surgiu no final dos anos 60 no Canadá, na Universidade de Mc Master (DOCHY et al., 
2003). Em nossa cultura é um método recente, foi introduzido nos anos 90 na medicina, a partir do Movimento Escola Nova (BARBOSA; CONTIJO; SANTOS, 2013).

Com ele as formas de ensino são revisadas e reformuladas, em que o aluno é sujeito de sua própria aprendizagem, trabalhando individualmente ou em grupos, buscando soluções para situações problemas apresentadas. Outro termo encontrado na literatura como referência a aprendizagem baseada em projetos é Project-Led Education. É um método muito utilizado, com nomenclaturas diferentes (HANNEY; SAVIN-BADEN, 2013). O trabalho com projetos rompe com as barreiras disciplinares, torna permeável as suas fronteiras e caminha em direção a uma postura interdisciplinar para compreender e transformar a realidade em prol da melhoria da qualidade de vida pessoal, grupal e global. (ALMEIDA, 1999).

De acordo com Perrenoud (1999) esse tipo de metodologia pretende melhorar as aprendizagens, contribuindo para o acompanhamento e orientação dos alunos durante todo o seu processo de formação. A partir da compreensão do corpo docente em relação à aplicação do método como mediador entre aluno e conhecimento, será mais fácil reconhecê-lo como um elemento facilitador e enriquecedor no âmbito escolar.

Sendo assim, a ABP é uma metodologia de ensino e aprendizagem inovadora. Incide sobre os conceitos e princípios de uma ou mais disciplinas, envolvendo os alunos em atividades de pesquisa para resolução de projetos e seus respectivos problemas relevantes, permitindo aos mesmos trabalhar de forma autônoma para construir o seu próprio saber, baseada em projetos de situações reais (HAWKINS et al., 2013). Permite aos educadores ministrarem aulas com uma maior proximidade aos alunos, à realidade e às necessidades atuais, possibilitando assim um melhor preparo do futuro profissional (BRUNEL; VIESC, 2014). Esse método busca resolver problemas e desenvolver o pensamento crítico para adquirirem princípios e concepções que possam permitir o uso de informações para os alunos aprenderem dentro de outras situações por vezes análogas. Esse método auxilia os estudantes a desenvolverem habilidades interpessoais e essências para trabalharem em equipe e terem a capacidade de envolver o professor, fazendo com que o mesmo saia de sua zona de conforto dentro de uma educação convencional centrada no mesmo, e assim passe a interagir com os alunos, relatando experiências e orientando-os na construção de conceitos, os quais ajudam a obter um nível mais profundo de entendimento e retenção de informações. 


\subsection{Justificativa}

Buscar conceitos que integram a $\mathrm{ABP}$ em problemas atuais é o primeiro desafio na aplicação dessa metodologia. A percepção que estamos vivendo um momento de questionamentos sobre o Meio Ambiente, nos dá uma oportunidade de problema a ser tratado.

Cada vez mais no Brasil e no mundo se vêm reafirmando a importância da Educação Ambiental como um dos eixos principais para a mudança nas relações do homem com o meio ambiente. Temas como: água, esgoto, lixo, saúde e ambiente, vêm sendo tratados numa perspectiva de responsabilidade individual e coletiva e passam a ser necessárias na educação. Além do debate educacional, a pressão social e regulatória surge cada vez mais nessa área.

Conforme o artigo 1ำ a Lei 9.795, de 27.04.1999 (BRASIL, 1999) que dispõe sobre a educação ambiental, esta apresenta-se como um componente fundamental para a educação, buscando a construção de valores, conhecimentos e habilidades para preservar o meio ambiente, de modo que seja garantida a qualidade de vida e a sustentabilidade. No Artigo 2o-, desta mesma lei, desataca-se que: “A educação ambiental é um componente essencial e permanente da educação nacional, devendo estar presente, de forma articulada, em todos os níveis e modalidades do processo educativo, em caráter formal e não formal”. Nesse contexto, a Educação Ambiental é um tema essencial na educação nacional, devendo estar presente em todos os níveis e modalidades de ensino.

Os Parâmetros Curriculares Nacionais (PCN) e as Resoluções do Conselho Nacional de Educação (CNE) também reconhecem a Educação Ambiental como uma temática a ser inserida no currículo dentro das disciplinas como um tema transversal (BRASIL, 1996). Nos PCN também há a indicação para se trabalhar o referido tema em questão, onde ressalta que:

O objetivo do trabalho com o tema meio ambiente é contribuir para a formação de cidadãos conscientes, aptos para decidirem e atuarem na realidade socioambiental de um modo comprometido com a vida, com o bem estar de cada um da sociedade. Para isso, é necessário que mais do que informações e conceitos a escola se proponha a trabalhar com atitudes, com formação de valores. (BRASIL, 1998, p. 20).

O tema Educação Ambiental, é pouco explorado por professores e alunos no Ensino Médio e Fundamental. É um tema que pode ser trabalhado por todas as disciplinas, nos dois níveis de ensino, funcionando como ferramenta para o desenvolvimento de projetos. 
Questões que envolvem o meio ambiente têm sido tratadas pelos professores, tradicionalmente, como ciência pura, como leitura e interpretação, exigindo um grande esforço de abstração para o seu aprendizado, embora o aluno não tenha sido preparado para essa tarefa (BRASIL, 1997). Essa situação pode criar um paradoxo, ou seja, se o aluno não souber abstrair o que for do seu interesse, pode ter uma visão errada sobre as questões ambientais e não desenvolver habilidades satisfatórias para sua atuação no mercado de trabalho.

Em toda a temática ambiental, pode-se encontrar vários temas que estão em constante discussão: aquecimento global, degradação da camada de ozônio, derretimento das geleiras, queimadas, poluição urbana, escassez e contaminação das águas, esgoto, lixo, dentre outros. Diante desses problemas é viável a aplicação desta temática em ABP, pois esse modelo de ensino permite confrontar os problemas ambientais, desenvolvendo nos alunos habilidades interpessoais, despertando o prazer pela pesquisa e a criatividade, permitindo confrontar os problemas ambientais que consideram significativos, buscando a resolução dos mesmos e diminuindo o impacto ambiental ou ainda encontrar uma maneira de minimiza-lo, para as próximas gerações. A ABP possibilita também a elaboração de um currículo em torno do problema ambiental, com ênfase na aprendizagem, desenvolvendo habilidades cognitivas, procedimentais e atitudinais.

Por que não aproveitar a experiência que têm os alunos de viver em áreas da
cidade descuidadas pelo poder público para discutir, por exemplo, a poluição dos
riachos e dos córregos e os baixos níveis de bem-estar das populações, os lixões
e os riscos que oferecem à saúde das gentes? (FREIRE, 2001, p. 33).

Dentro deste contexto, faz-se necessário atrair os alunos para esses problemas, buscando melhorias por meio de projetos. Desse modo, utilizar a ABP, desenvolve no aluno a competência de dar significado ao que está sendo aprendido e ao educador, a possibilidade de trabalhar através de vivências concretas e diversificadas, envolvendo o educando no conteúdo trabalhado, fazendo do aprendizado uma prática prazerosa.

No Brasil, a aprendizagem no ensino médio e no ensino fundamental vem apresentando deficiências que repercutem de forma negativa. Muitos jovens abandonam o curso, antes mesmos de concluir, para entrar no mercado de trabalho, o que causa a evasão escolar. Inúmeros são os fatores pelos quais o aluno abandona a escola. Dentre eles, os que mais chamam a atenção são os alunos responsáveis em ajudar em casa e sustentar a família e alunos que encontram dificuldades em conciliar o horário do trabalho com a escola. Por meio da prática pedagógica, observa-se que o aluno sendo jovem, ainda adolescentes, se vê 
obrigado a escolher uma profissão, sem saber exatamente o que ela oferece. Diante desse quadro, o desafio se torna maior e mais difícil: estimular o aluno a concluir o ensino fundamental ou médio.

Como forma de tratar esses e outros problemas que surjam, os pesquisadores em métodos de ensino e aprendizagem concentram seus esforços na busca da evolução das técnicas que os ajudem a superar as dificuldades encontradas. Atualmente as facilidades de acesso à informação e ao uso de recursos computacionais, permitem a aplicação de métodos inovadores, que motivem o desenvolvimento das habilidades e competências do educando, por meio de problemas reais. Para isto deve-se trabalhar estimulando o aluno á prática e a aplicação de diversos métodos e ferramentas por meio de novas metodologias de ensino-aprendizagem, como propõe a ABP.

Dym e Little (2010) comentam que para pôr em prática esta abordagem da aprendizagem, deve- se entender que a atuação do docente é de facilitador e orientador do processo de aprendizagem dos alunos, o qual deve conduzir o aluno à construção de conhecimentos por conta própria.

Além da metodologia de ensino aprendizagem para apoiar esse trabalho, existe a necessidade de formas diversificadas de avaliação, levando-se em conta a parte prática e a motivação dos alunos. É fundamental então propor nesse trabalho uma metodologia adequada para utilização em ABP no ensino médio e fundamental. Como fazer uma abordagem em sala de aula e como analisar os resultados que serão obtidos e também questões a serem respondidas neste trabalho. Isso leva as seguintes questões norteadoras:

- os alunos percebem uma aprendizagem facilitada com esta abordagem?

- poderia uma disciplina em ABP motivar o aluno e auxiliá-lo no desenvolvimento de competências e habilidades para enfrentar os problemas da vida real?

- quais as estratégias que poderiam ser utilizadas para avaliar a evolução teórico prática dos alunos?

- é possível avaliar o processo de ensino aprendizagem por meio de um modelo que integra a teoria e prática, considerando a subjetividade do método?

A partir dessas questões, esse trabalho apresenta uma metodologia de ensino baseado em ABP, em especial para a educação ambiental, no sentido de vincular este tema ao seu objetivo original: o projeto. Desta forma, as técnicas de representação, e métodos descritivos têm como enfoque principal a solução de problemas reais.

O desenvolvimento dessa pesquisa é apresentado em 5 capítulos. O primeiro capítulo retrata a introdução e a justificativa do trabalho e objetivos gerais e específicos 
para serem alcançados. O Capítulo 2 apresenta-se a fundamentação teórica embasando a $\mathrm{ABP}$, onde são apresentados os principais conceitos necessários para o desenvolvimento dessa metodologia ativa de ensino e aprendizagem, e também a aplicação desse método na Educação Ambiental. Apresenta-se também a importância do ensino de ciências, na perspectiva de Monteiro (2002). O terceiro capítulo apresenta a metodologia que seguiu os pressupostos da Pesquisa-ação embasada em Ludke e André (1986). Ainda apresenta os instrumentos que foram utilizados na coleta e análise dos dados. O quarto capítulo, descreve as 40 semanas de metodologia, do projeto, a interdisciplinaridade e a confirmação da coleta de dados. O quinto capítulo, apresenta as considerações finais da pesquisa desenvolvida, suas contribuições e sugestões para trabalhos futuros.

\subsection{Objetivos}

\subsubsection{Objetivo Geral}

Diante do desafio em contribuir com o aprimoramento de metodologias de ensino e aprendizagem, este trabalho tem então o principal objetivo de comprovar se o método de ensino baseado em projetos é aplicável para a educação ambiental por meio da interdisciplinaridade, envolvendo as disciplinas de Geografia, Física, Matemática, História, Arte e Língua Portuguesa e ainda apresentar um modelo teórico prático para implementação e avaliação do método.

\subsubsection{Objetivos Específicos}

Complementando o objetivo geral desta pesquisa, foram também definidos os seguintes objetivos específicos:

- compreender o conceito de Educação Ambiental e Sustentabilidade, estabelecendo relação entre eles;

- motivar os educandos e auxiliá-los no desenvolvimento de competências e habilidades para enfrentar situações problemas da vida real;

- estimular a investigação científica;

- utilizar as tecnologias como ferramentas pedagógicas.

- analisar por meio de indicadores, os benefícios gerados pela aplicação do método;

- solucionar problemas utilizando o senso crítico para intervenções pontuais a nível pessoal, local e global. 


\section{METODOLOGIAS ATIVAS E ENSINO DE CIÊNCIAS}

\subsection{O Ensino de Ciências}

O conhecimento científico se orienta pela prática indutiva, utilizando uma série de etapas como: observação e experimentação, generalização indutiva, formulação de hipóteses, tentativa de verificação, comprovação ou recusa e obtenção de conhecimento objetivo. Assim, a concepção de ciência é empirista indutivista para os alunos e também para os professores (SILVA; ZANON, 2000).

Se prestarmos atenção ao ensino do país, atualmente, é possível perceber que ele enfrenta grandes questionamentos, como a capacitação dos professores e o processo de ensino e aprendizagem, tanto por parte de alunos e dos pais, quanto dos professores e da própria proposta pedagógica. Nesta perspectiva, seguem as observações de Fourez (2003) quando fala numa crise nessa área. Ele afirma que são atingidos "os alunos, os professores de ciências, os dirigentes da economia, os pais, os cidadãos [...]” (FOUREZ, 2003, p. 110).

Os documentos propostos pela Academia Brasileira de Ciências destacam a necessidade de melhorar o ensino básico no Brasil e, em especial, o ensino de ciências (ACADEMIA BRASILEIRA DE CIÊNCIAS, 2008). O mesmo, quando bem trabalhado, estimula o raciocínio lógico e a curiosidade, a formação de cidadãos mais preparados para enfrentar as dificuldades que a sociedade atual apresenta e o fortalecimento da democracia, dando boas condições para participação de debates cada vez mais sofisticados sobre temas científicos que interferem no dia a dia. Além disso, somos impulsionados por um mundo científico-tecnológico, que exige dos cidadãos um conhecimento mais apurado de todas as áreas do saber e os conhecimentos científicos se tornam imprescindíveis para o progresso e sobrevivência, numa sociedade em constante mudança. O saber científico é uma ciência que vai possibilitar ao aluno, acompanhar, argumentar e enfrentar esses novos desafios.

De acordo com Monteiro (2002, p. 53) "Quanto mais cedo os alunos forem estimulados a participar do processo de construção de argumentos, mais facilmente eles se engajarão nessa prática e mais significativos serão os resultados". Uma observação mais detalhada da história mostra que o ensino de ciências evoluiu de acordo com as circunstâncias, a época, os fatores políticos, econômicos, sociais e culturais. Essa área vem progredindo cada vez mais, o que proporciona aos alunos uma atitude positiva em relação às transformações que ocorrem.

Esta questão é fortalecida pelos PCNs, (BRASIL, 1997). Segundo esse documento:

Mostrar a Ciência como um conhecimento que colabora para a compreensão do 
mundo e suas transformações, para reconhecer o homem como parte do universo e como indivíduo, é a meta que se propõe para o ensino da área na escola fundamental. A apropriação de seus conceitos e procedimentos pode contribuir para o questionamento do que se vê e ouve, para a ampliação das explicações a cerca dos fenômenos da natureza, e compreensão e valorização dos modos de interferir na natureza e de utilizar seus recursos, para a compreensão dos recursos tecnológicos que realizam essas mediações, para a reflexão sobre questões éticas implícitas nas relações entre Ciência, Sociedade e Tecnologia (BRASIL, 1997, p.23).

No ensino de ciências, o bom resultado das atividades desenvolvidas em sala de aula exige do professor um bom planejamento, cujo trabalho é instigar o aluno a buscar respostas aos seus questionamentos e também soluções para os problemas. Conforme o desenrolar do trabalho, o aluno desenvolverá algumas habilidades e aprenderá a lidar com diversas situações (BRITO; MANATTA, 1994, p. 254).

Segundo Fracalanza, Amaral e Gouveia (1986) o ensino de ciências, além de possibilitar o domínio da escrita e leitura, permite que o educando aprenda conceitos básicos das ciências naturais, aplicando seus conhecimentos em situações práticas, que envolvam a ciência e a sociedade, garantindo a sistematização dos saberes e da cultura.

Portanto, é possível afirmar que "Para o exercício pleno da cidadania, um mínimo de informação básica em ciências deve ser desenvolvido, de modo a fornecer instrumentos que possibilitem uma melhor compreensão da sociedade em que vivemos" (DELIZOICOV; ANGOTTI, 1990, p. 56).

\subsection{Aprendizagem Baseada em Projetos (ABP)}

A Aprendizagem Baseada em Projetos (ABP) é uma estratégia educacional centrada no aluno, que o ajuda a desenvolver o raciocínio e a comunicação. É um método de ensino ativo cujo objetivo é envolver os alunos na aquisição de conhecimentos e habilidades por meio de uma atividade real e que seja bem planejada (PEREIRA; BORTOTI; SANTOS, 2013).

Proporcionar a esse aluno situações reais para que possa desenvolver suas habilidades e competências e aplicá-las no dia-a-dia é o objetivo da ABP fundamental, para que ele aprenda a pensar em grupo e trocar experiências.

Na visão de Wang (2015) em métodos de ensino mais dinâmicos, o aluno ocupa uma posição de agente ativo dentro do processo de aprendizagem, por meio de atividades estimuladoras do desenvolvimento e da capacidade de iniciativa e descobrimento, 
propiciando uma aprendizagem contínua e dinâmica. O principal papel do professor passa a ser o de ajudar o aluno a aprender, e não mais o de ensinar (KONG et al., 2014).

Santos e Pereira (2014) mostram no Quadro 1 a seguir as diferenças da abordagem Convencional do ensino para a abordagem da Aprendizagem Baseada em Projeto.

Quadro 1 - Comparativo entre a abordagem convencional do ensino e a ABP

\begin{tabular}{|c|c|}
\hline Abordagem Convencional & Aprendizagem Baseada em Projetos \\
\hline - Docente assume o papel de especialista & $\begin{array}{l}\text { Docente é facilitador, orientador, mentor ou } \\
\text { consultor profissional. }\end{array}$ \\
\hline Docentes trabalham isoladamente. & - Docentes trabalham em equipes. \\
\hline $\begin{array}{l}\text { - Alunos são vistos como tabula rasa ou } \\
\text { receptores passivos de informação. }\end{array}$ & $\begin{array}{l}\text { Docentes valorizam os conhecimentos prévios } \\
\text { dos alunos, buscam encorajar a iniciativa deles e } \\
\text { delegam a eles, autoridade com responsabilidade. }\end{array}$ \\
\hline - Alunos trabalham isoladamente. & $\begin{array}{l}\text { Alunos interagem com o corpo docente de modo } \\
\text { a fornecer feedback imediato sobre o curso com a } \\
\text { finalidade de melhorá-lo. }\end{array}$ \\
\hline $\begin{array}{l}\text { - Aula baseada em comunicação } \\
\text { unilateral; } \\
\text { - Informação é transmitida a um grupo } \\
\text { de alunos. }\end{array}$ & $\begin{array}{l}\text { - Alunos trabalham em grupos para resolver } \\
\text { problemas; } \\
\text { - Alunos adquirem e aplicam conhecimento em } \\
\text { contextos variados; } \\
\text { Alunos encontram seus próprios recursos e } \\
\text { informações orientados pelos docentes; } \\
\text { - Alunos buscam conhecimentos e habilidades } \\
\text { relevantes a sua futura prática profissional. }\end{array}$ \\
\hline
\end{tabular}

Fonte: Adaptado de Santos e Pereira (2014).

A metodologia de aprendizagem baseada em projetos ou problemas é caracterizada pelo uso de questionamentos e casos do mundo real, para encorajar os alunos a desenvolverem pensamento crítico e habilidades de desenvolvimento e solução de problemas, adquirindo conhecimento sobre os conceitos essenciais da área em questão (NANDA; MANJUNATHA, 2013). Segundo Ribeiro; Escrivão Filho e Mizukame (2004) o método pode ser implementado em todo um curso ou como estratégia educacional parcial e até em disciplinas isoladas.

No método o aluno é exposto a situações motivadoras em grupos tutoriais, por meio de um projeto, para poder definir objetivos de aprendizado sobre os temas do currículo (WRIGH; WICKHAN; SACH, 2014). Um dos fundamentos principais do método é ensinar o aluno a aprender, buscando conhecimento em meios de difusão variados. Com isso, além de se manter atualizado com o assunto, o aluno desenvolve agilidade para solucionar problemas e criatividade para explorar novos métodos de organização. Os 
resultados fazem com que o aluno tenha uma independência maior, retenha os conhecimentos adquiridos por mais tempo e desenvolva uma postura de estudo permanente (LONG; QIN, 2014).

Diversos autores aplicaram a ABP com resultados importantes, em áreas diversas do conhecimento, dentre elas a Educação (e suas variadas aplicabilidades), Saúde, Tecnologia e Engenharia, salvo ainda a possibilidade de divisões em subáreas. É fato que uma classe apresenta alunos com diferentes níveis de conhecimento prévio. Dolmans e Gijbels (2013) pesquisaram os efeitos da ABP sobre esses diferentes alunos e relataram que o método pode promover abordagens desejáveis à aprendizagem. Relatos significativos sobre melhorias nas habilidades de questionamento dos alunos também foram apontados por Hung et al. (2014), em um estudo sobre os efeitos da ABP, bem como Lee, Huh e Reigeluth (2015) comprovaram que a aplicação do mesmo método melhorou as habilidades sociais dos alunos e suas formas de lidar com conflitos interpessoais.

Ainda aliados à educação, Vega e Brown (2013) realizaram um estudo fenomenológico, confrontando a ABP com outros métodos de ensino, desenvolvendo nos alunos as habilidades necessárias para enfrentar o século 21. Granzotti et al. (2015) problematizaram um contexto construído a partir de situações-problema como disparadoras do processo de ensino- aprendizagem em metodologias ativas de ensino, acreditando na possibilidade de haver melhorias na qualidade da educação formal.

Os autores Wiek et al. (2013) utilizaram a ABP na demonstração de que os alunos desenvolveram capacidades para enfrentar e resolver problemas de sustentabilidade no mundo real, adquirindo competência para colaborar com parceiros de governo, empresas e sociedade civil. Citaram também que as experiências e os resultados apresentados podem ajudar outros programas nessas colaborações.

Jerzembeka e Murphya (2013) aplicaram a ABP no ensino fundamental verificando seus efeitos sobre o desenvolvimento acadêmico e pessoal. Kim e Lee (2014) propuseram um método para o ensino de habilidades de processamento de informação por um modelo de aprendizagem baseada em problemas e testado com alunos desse nível. Citam ainda que a ABP apresenta uma metodologia adequada para o ensino de habilidades de processamento de informação. Frezatti et al. (2016) consideram que a ABP é um grande instrumento para levar a cabo a complexidade da perspectiva sinérgica do CHA (Conhecimentos, Habilidades e Atitudes), observando pelo menos um vínculo com o problema exposto por meio da comunicação oral e escrita (e uso de pôsteres apresentados de forma oral ou escrita) (TAN; GOH; YAP, 2015). 
Aplicando e analisando o impacto da ABP no desempenho acadêmico no Ensino Médio, por meio de revisão sistemática, Wildera (2015) constatou a eficácia do método nessa fase escolar. Criticamente, Melo e Sant'Ana (2012) analisaram ainda as vantagens e fragilidades da metodologia ativa e habilidades adquiridas para a vida profissional dos discentes, relatando a compreensão dos conteúdos e transformando-os em autores do próprio processo ensino- aprendizagem.

Para estudantes do Ensino Médio de escolas públicas e privadas, Ritter et al. (2013) utilizaram a ABP na criação de uma oficina de biodiesel como estratégia de aprendizagem, buscando resolução de situações-problema. Os autores constataram que a maioria dos estudantes considerou a temática necessária, principalmente para promover a qualidade de vida e diminuir a emissão de poluentes atmosféricos.

A aprendizagem em alunos adultos também foi analisada por Hung (2014) que utilizou a ABP para a melhoria do ensino de design instrucional. No ambiente universitário, os métodos ativos satisfizeram os estudantes da disciplina de Ética em Saúde, é o que nos prova às técnicas de Christofoletti et al. (2014). Duarte, Monaco e Manso, (2013) também demonstraram que a ABP se aplica também no ensino das chamadas ciências básicas (e não somente das disciplinas técnicas), desenvolvendo o raciocínio clínico e o estímulo à busca do conhecimento por meio do estudo autodirigido.

Silva et al. (2014) relataram uma experiência inovadora na utilização de metodologias ativas de ensino-aprendizagem e avaliação no ensino das Políticas de Saúde e Cidadania. Citam que as metodologias ativas estimularam a autonomia, crítica e reflexão, empoderando os estudantes para o exercício da ética e o trabalho em equipe com responsabilidade, perante as questões do cotidiano da vida. Preet, Ashish e Shriram (2013) utilizaram a ABP e comprovaram a eficiência dela em comparação com a aprendizagem baseada em teoria convencional. Mencionaram uma melhoria significativa no desempenho geral observado, comprovado através do feedback, que revelou concordância da maioria a aprendizagem baseada em problemas. Para potencializar os conhecimentos acumulados pelos alunos e ajudar na resolução de problemas, Matsuyama, Bezzon e Santos (2014) aplicaram o método ABP e escreveram que os alunos foram capazes de compreender e racionalizar o objetivo de cada disciplina.

Da análise do aluno à formação do professor, encontramos em Richartz (2015) a referência à contribuição da $\mathrm{ABP}$ na formação do docente, organizando o ensinoaprendizagem a partir da pesquisa. Moreno, Reis e Calefi (2013) investigaram as concepções dos professores, nas áreas de Biologia, Física e Química em relação à ABP. 
Demonstraram que os professores entenderam a metodologia, acharam-na interessante, mas refutaram em utilizá-la porque demandaria uma formação mais abrangente ou uma capacitação em serviço.

Há importantes relatos acadêmicos sobre uma nova experiência educacional dentro do conceito de ABP e do uso de informações e tecnologias de comunicações, como Aussin et al. (2016) que demonstraram através da ABP que os alunos ficaram satisfeitos com um programa de rádio criado no projeto realizado e todos concordaram com a relevância do projeto em si. Chao, Chen e Chuang (2015) demonstraram que alunos que tomaram um currículo de nível introdutório sobre desenho assistido por computador, fazendo uma ponte entre a aprendizagem e o currículo no ensino da engenharia do ensino médio, tiveram a aprendizagem beneficiada.

O método da ABP, aplicada na revolução da robótica educacional livre no ambiente das escolas públicas, teve um resultado satisfatório. Silva et al. (2016). Foi utilizado lixo eletrônico ao invés de soluções comerciais para construção de robôs, o que possibilitou ao aluno ampliar sua visão sobre as aplicações tecnológicas em seu contexto socioeducativo. Através desse método, os autores constataram que a robótica na escola é uma atividade capaz de manter os jovens afastados das ruas e de lhes proporcionar uma formação ampliada multidisciplinar, reduzindo a sua vulnerabilidade por estar afastado das ruas e com outros objetivos.

Em um curso de Engenharia, Rocha e Lemos (2014) aplicaram as ferramentas e técnicas da $\mathrm{ABP}$ e observaram as vantagens da metodologia ativa logo no início do processo. Os resultados atestaram as vantagens em termos de engajamento (acima de $80 \%$ ), desempenho acadêmico (notas abaixo de 5,0 passaram de $60 \%$ para $8 \%$ ) e aumentou a satisfação dos alunos envolvidos quando comparado com os métodos tradicionais de ensino. Ainda em cursos de Engenharia, Bortoti, Santos e Pereira (2013) relataram uma experiência positiva na aplicação da $\mathrm{ABP}$ e constatarem que o método acelerou o desenvolvimento das competências transversais dos alunos, contribuindo para um aproveitamento do desenvolvimento pessoal e profissional.

$\mathrm{Na}$ área da saúde, há estudos de Queiroz et al. (2016) que relatam, por meio de experiência com universitários, o uso da ABP com resultados positivos em projetos de inovação tecnológica, promovendo integração e fazendo diferença no processo de ensinoaprendizagem dos agentes envolvidos no ensino de Odontologia. Já no ensino de Medicina, Leon e Onófrio (2014) demonstraram bons resultados quando utilizada a ABP, principalmente no que diz respeito ao pensamento crítico e habilidades técnicas. 
Um aspecto importante a ser considerado no projeto, é a relevância dos assuntos pesquisados na comunidade acadêmica, em que os autores apresentaram resultados positivos em relação à aplicação do método ABP. Isso é demonstrado na Figura 1 e na figura 2, onde é possível observar a tendência de publicações e citações nos últimos anos do ensino médio e do ensino fundamental.

A figura 1 foi gerada a partir dos dados da ISI Web of Knowledge e ilustra a pesquisa realizada para o termo, em inglês, "Project Based Learning" and "K12" (Elementar School). Com essa busca demonstrou - se que o tema é pouco citado e referenciado em "K12”. A mesma pesquisa foi realizada para ambos os termos, em inglês, "Project-Based Learning" and "High School", termo esse utilizado para identificar o ensino médio em língua inglesa, que é demonstrado pela Figura 2. Embora haja um pequeno número de publicação sobre o assunto no ensino médio, não existe grande volume de publicações e nem citações nos últimos anos. Mediante isso conclui-se que há na literatura, uma lacuna em trabalhos que abordam simultaneamente, os temas Aprendizagem Baseada em Projetos e Ensino Médio.

Figura 1 - Publicações (a) e citações (b) para o termo "Project-Based Learning" and "K12"
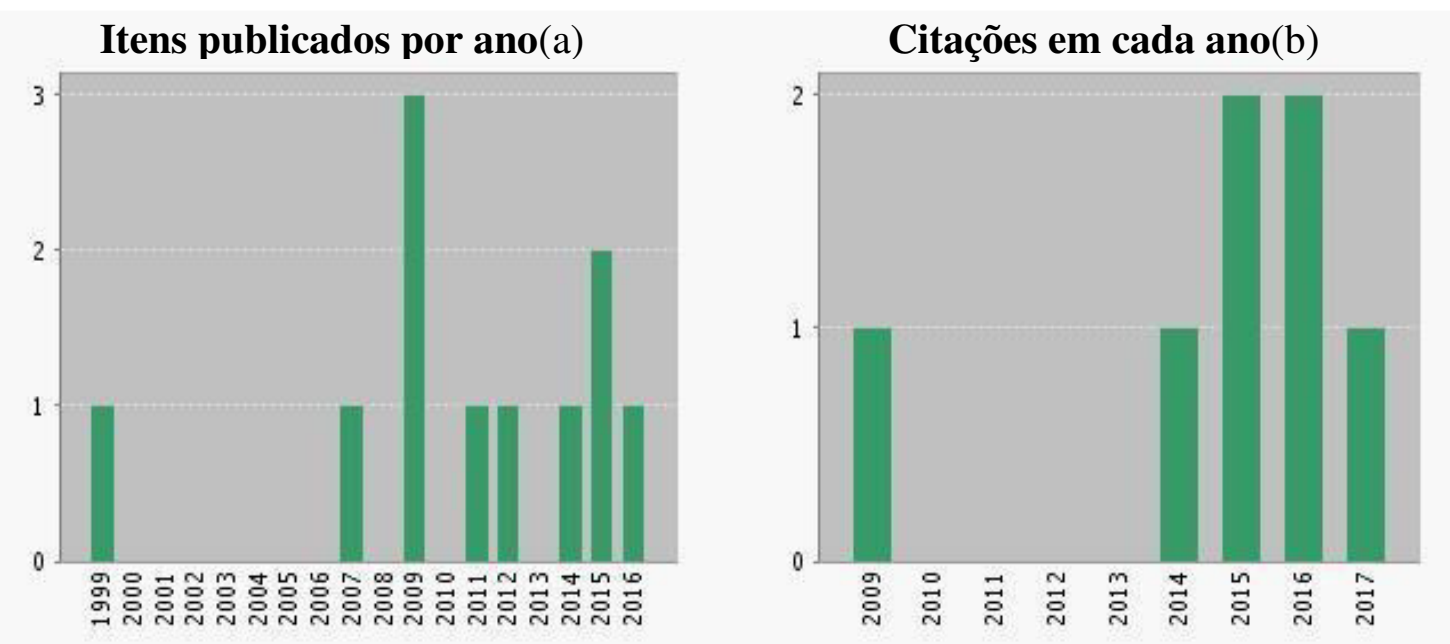

Fonte: ISI Web of Knowledge. 
Figura 2 - Publicações (a) e citações (b) para os termos "Project Based Learning" and "High School"
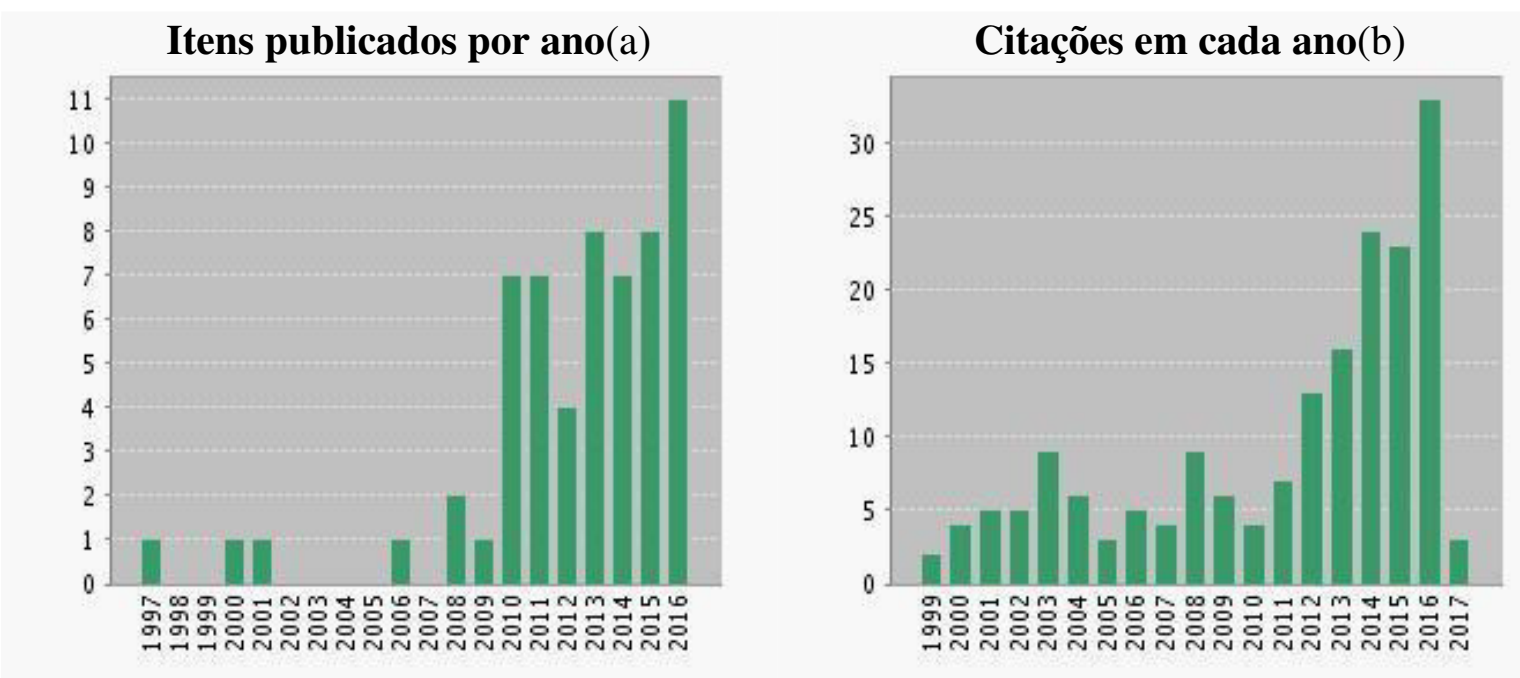

Fonte: ISI Web of Knowledge.

Também é viável ressaltar que na literatura não foi encontrado nenhum resultado idêntico ao presente trabalho, o que comprova que o tema escolhido para pesquisa “Aprendizagem Baseada em Projetos aplicada no ensino médio e no ensino fundamental", se torna relevante à comunidade científica brasileira.

\subsection{Processos de Avaliação do Ensino e Aprendizagem}

Na sociedade atual percebe-se que a atitude dos profissionais da educação é meramente avaliar o certo ou errado na sua própria visão. Preocupados somente com os méritos de avaliação tradicional, esquecem que a construção do conhecimento e explicações teóricas, exige uma análise diante da que se vive. $\mathrm{O}$ assunto nota da prova sempre foi confundido pelos pais, professores e alunos como uma metodologia de instrução. Acreditando esses, que avaliando as provas como certas ou erradas resultaria em uma melhor apreensão do conteúdo (MARINHO; FERNANDES; LEITE, 2014). Todavia, essa forma de correção imediata, acaba induzindo as crianças às respostas já prontas apesar do não entendimento dessas questões.

Segundo Esteban (2001) frequentemente a avaliação feita pelo professor se fundamenta na fragmentação do processo ensino e aprendizagem e na classificação das respostas de seus alunos, a partir de um padrão predeterminado, relacionando a diferença ao erro e a semelhança ao acerto. Quando existe a possibilidade de eliminação de provas nas escolas, há inúmeros defensores dessa ideia, como se elas fossem uma penosa obrigação a cumprir na sua profissão (MARCHÃO; FITAS, 2014). Como a avaliação é a 
constatação de resultados, o professor pode passar seu conhecimento sem se preocupar com o entendimento do aluno. O não repensar da prática avaliativa no ensino coloca em risco esse aprendizado.

Hoffmann (2009) cita que os educadores temem a inovação à metodologia tradicional de aplicação de provas e atribuição de notas / conceitos periódicos, pelo fato de perder o controle sobre os educandos. Dessa forma, torna-se necessário o repensar do docente sobre suas metodologias de avaliação, pois cada educando tem uma maneira diferente de compreender os conteúdos, ou seja, capacidades cognitivas de compreensão.

A competência requerida hoje em dia é a faculdade de mobilizar um conjunto de recursos cognitivos (saberes, capacidades, informações etc.). Para solucionar com pertinência e eficácia uma série de situações (PERRENOUD, 1999, p. 30).

Ainda de acordo com Perrenoud (1999, p. 57), no campo dos aprendizados gerais, um estudante será levado a construir competências de alto nível somente confrontando - se, regular e intensamente, com problemas numerosos, complexos e realistas, que mobilizem diversos tipos de recursos cognitivos, os quais primeiramente são trabalhados de uma forma individual e depois em grupo. Assim, o método avaliativo deve ser posto como um princípio que produza qualidade conduzindo o educando a conciliar teoria e prática, através da autonomia intelectual. As práticas educativas como seminários, trabalhos em grupo, debates, pesquisas, elaborações de textos acerca do assunto trabalhado e as discussões sobre as atividades realizadas na sala de aula, são métodos que podem ser explorados pelo professor diante da heterogeneidade da turma, valorizando o conhecimento individual de cada aluno. 


\section{METODOLOGIA DA PESQUISA}

Para realizar uma pesquisa é necessário um trabalho intenso e minucioso, é necessário confrontar os dados apresentados, as evidências, as informações, as coletas sobre o assunto e um conhecimento teórico sólido adquirido no processo de investigação. Em geral, isso ocorre a partir do estudo de uma situação problema que surgiu da curiosidade e necessidade do pesquisador em busca de respostas (LUDKE; ANDRÉ, 1986). As estratégias variam em: estudo de caso (que investiga um fenômeno), levantamento (survey - que estuda a causa e o efeito sobre as variáveis), experimento (estuda a causa e o efeito de variáveis independentes), análise de arquivos (ou bibliográfica, histórica), ou por pesquisa-ação (YIN, 2010).

A metodologia dessa pesquisa segue o que está fundamentado por Ludke (1986) que define a pesquisa - ação como um momento privilegiado, reunindo o pensamento e ação de uma pessoa, ou de um grupo, no esforço de elaborar o conhecimento de aspectos da realidade que deverão servir para a composição de soluções propostas aos seus problemas. Sendo assim, foi possível a aplicação desta metodologia, devido à participação direta do pesquisador com o alvo de análise (SANTOS; LIMA, 2010). Durante a pesquisa, a atuação do mesmo ocorrerá como principal condutor da disciplina, propondo as atividades estruturadas sob os princípios do método e conduzindo o desenvolvimento das pesquisas conceituais e dos relatórios dos alunos.

\subsection{Classificação da Pesquisa-ação}

O método é pesquisa-ação, de natureza qualitativa e objetivo descritivo, e investiga, de forma empírica, a análise da avaliação do programa da disciplina desenvolvida através de um estudo de avaliação de programa. Para Marconi e Lakatos (2004) é um estudo que procura os efeitos e seus resultados em um método específico relativo à educação. $\mathrm{Na}$ educação seu objetivo é garantir um ensino de qualidade e uma aprendizagem eficaz.

Diante do contexto de avaliação do conteúdo e da aprendizagem, surge uma questão: como desenvolver educação ambiental por meio de um modelo que avalie o aprendizado de pressupostos teóricos associados à prática do projeto? Inclui-se então nesta pesquisa a apresentação de um modelo de avaliação baseado em pesquisa açãoinvestigativa. A metodologia proposta está apoiada em dois pilares fundamentais que são: um novo enfoque na apresentação dos conteúdos, baseado em situações concretas com uma nova metodologia de ensino, onde os alunos utilizam os conceitos de educação ambiental 
no desenvolvimento de projetos, e um método de avaliação para desenvolver a investigação, foi feito uso da Pesquisa- ação, caracterizada como um estudo que ocorre em um local, compor exemplo, a sala de aula e mediante um problema, procura-se entendê-lo e solucioná-lo. Neste tipo de estudo o observador pode ser participante (LUDKE; ANDRÉ, 2013). A pesquisa pode ser classificada quanto às abordagens - Qualitativa e Quantitativa; quanto à natureza - Básica e Aplicada; quanto aos objetivos - Exploratória, Descritiva e Explicativa e quanto aos procedimentos - Experimental, Bibliográfica, Documental, de Campo, Ex-post-facto, de Levantamento, com Survey, Estudo de Caso, Participante, Etnográfica, Etnometodológica e Pesquisa-ação.

O quadro 2 descreve as características de cada pesquisa:

Quadro 2 - Características da pesquisa

\begin{tabular}{|c|c|c|}
\hline \multicolumn{2}{|c|}{ Pesquisa } & Característica \\
\hline \multirow{2}{*}{ 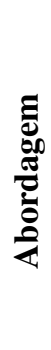 } & Qualitativa & $\begin{array}{l}\text { É descritiva e o pesquisador é o instrumento-chave, existe uma relação } \\
\text { dinâmica entre o mundo real e o sujeito, visto que o ambiente natural é fonte } \\
\text { direta para coletar dados que são analisados intuitivamente. }\end{array}$ \\
\hline & Quantitativa & $\begin{array}{l}\text { Tem suas raízes no pensamento positivista lógico, tende a enfatizar o raciocínio } \\
\text { dedutivo. Classifica e analisa as informações e opiniões traduzidas em números } \\
\text { e por isso requer o uso de recursos e de técnicas estatísticas }\end{array}$ \\
\hline \multirow{2}{*}{ 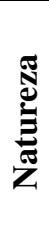 } & Básica & $\begin{array}{l}\text { Produz conhecimentos novos úteis para o avanço da ciência sem aplicação } \\
\text { prática prevista. Envolve verdades e interesses universais. }\end{array}$ \\
\hline & Aplicada & $\begin{array}{l}\text { Gerada a partir de conhecimentos para aplicação prática dirigida à solução de } \\
\text { problemas específicos. Envolve verdades e interesses locais. }\end{array}$ \\
\hline \multirow{3}{*}{ 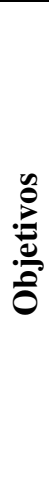 } & Exploratória & $\begin{array}{l}\text { Esclarecer e modificar os conceitos e ideias, tendo em vista a formulação de } \\
\text { problemas mais precisos ou hipóteses pesquisáveis para estudos posteriores. } \\
\text { Apresenta menor rigidez no planejamento. }\end{array}$ \\
\hline & Descritiva & $\begin{array}{l}\text { Descrever as características de determinadas populações ou fenômenos. Uma de } \\
\text { suas peculiaridades está na utilização de técnicas padronizadas de coleta de } \\
\text { dados, como ex: questionário e a observação sistemática. }\end{array}$ \\
\hline & Explicativa & $\begin{array}{l}\text { Identificar os fatores que contribuem para a ocorrência dos fenômenos ou } \\
\text { variáveis que afetam o processo. Explica o porquê das coisas. }\end{array}$ \\
\hline \multirow{2}{*}{ 胥 } & Experimental & $\begin{array}{l}\text { Aplica-se quando se tem um objeto de estudo, selecionam-se variáveis de } \\
\text { influência e definem-se formas de controle e observação dos efeitos. Segue um } \\
\text { planejamento rigoroso. }\end{array}$ \\
\hline & Bibliográfica & $\begin{array}{l}\text { Realiza-se por meio de levantamentos de materiais já publicado, e constituído } \\
\text { principalmente de livros e artigos científicos. }\end{array}$ \\
\hline
\end{tabular}


(conclusão) Quadro 2 - Características da pesquisa.

\begin{tabular}{|c|c|c|}
\hline \multirow{10}{*}{ 胥 } & Documental & $\begin{array}{l}\text { Realizada a partir de documentos, contemporâneos ou retrospectivos, } \\
\text { considerados cientificamente autênticos, como dados estatísticos, cartas, } \\
\text { fotografias, filmes, atas, relatórios e obras originais de qualquer natureza. }\end{array}$ \\
\hline & Campo & $\begin{array}{l}\text { Gerada por meio da observação direta das atividades do grupo estudado e de } \\
\text { entrevistas com informantes para explicar e interpretar o que ocorre na } \\
\text { realidade. }\end{array}$ \\
\hline & Ex-post-facto & $\begin{array}{l}\text { Investiga as relações de causa e efeito entre um fato identificado pelo } \\
\text { pesquisador e um fenômeno que ocorre posteriormente. }\end{array}$ \\
\hline & Pesquisa-ação & $\begin{array}{l}\text { Planejada e realizada em estreita associação com uma ação ou com a resolução } \\
\text { de um problema coletivo no qual os pesquisadores e os participantes estão } \\
\text { envolvidos de modo cooperativo ou participativo. }\end{array}$ \\
\hline & Survey & $\begin{array}{l}\text { Busca o questionamento direto das pessoas cujo comportamento deseja } \\
\text { conhecer e analisar. O indivíduo pesquisado não é identificado. }\end{array}$ \\
\hline & Estudo de caso & $\begin{array}{l}\text { Envolve uma pesquisa profunda e exaustiva de um ou poucos objetos com o } \\
\text { objetivo de permitir o seu amplo e detalhado conhecimento. }\end{array}$ \\
\hline & Participante & Envolvimento do pesquisador com os membros das situações investigadas. \\
\hline & Etnográfica & $\begin{array}{l}\text { Apresenta e traduz a prática da observação, da descrição e da análise, de uma } \\
\text { equipe ou uma população. }\end{array}$ \\
\hline & Etnometodológica & Estuda as estratégias que os indivíduos recorrem para as suas ações diárias. \\
\hline & Levantamento & $\begin{array}{l}\text { Utilizado em estudos exploratórios e descritivos, classificada como } \\
\text { levantamento de uma amostra ou de uma população. }\end{array}$ \\
\hline
\end{tabular}

Fonte: Adaptado de LAKATOS e MARCONI (2004) e GIL (2008).

\subsection{Etapas da Pesquisa}

Pode-se definir pesquisa como o processo formal e sistemático de desenvolvimento do método científico. O objetivo fundamental da pesquisa é buscar respostas para problemas mediante o emprego de procedimentos científicos. De acordo com Thiollent (1996), um conjunto de condições de compromisso participativo é necessário para tornar o projeto de pesquisa-ação sustentável é apresentado.

- A iniciativa de pesquisa parte de uma demanda de pessoas ou grupos de pessoas que ocupam as posições de topo do poder;

- Os objetivos são definidos com autonomia dos atores e com mínima interferência de membros da estrutura formal;

- Todos os grupos sociais implicados no problema escolhido como assunto da pesquisa são chamados para participar do projeto e de sua execução;

- Todos os grupos têm liberdade de expressão. Medidas são tomadas para evitar 
censuras ou represálias;

- Todos os grupos são informados no desenrolar da pesquisa;

- As possíveis ações decorrentes da pesquisa são negociadas entre os proponentes e os membros da estrutura formal;

- Em geral, as equipes internas que promovem a pesquisa são auxiliadas por consultores ou pesquisadores externos.

Na visão de Gil (2008) considera que, por meio desse processo de pesquisa e intervenção, as pessoas envolvidas em determinada problemática e que participam da busca de soluções beneficiam-se não só com os resultados da pesquisa, mas também durante seu desenvolvimento, o que é próprio da metodologia da pesquisa-ação.

Essa metodologia é adequada à pesquisa porque permite a construção e reconstrução de significados e apresenta um modelo qualitativo. É objeto de experimentação tanto no plano do conhecimento quanto no da prática social (THIOLLENT, 1996).

A Figura 3 mostra a classificação dessa pesquisa com relação à sua natureza, objetivo, abordagem e método.

Figura 3 - Classificação da Pesquisa Científica

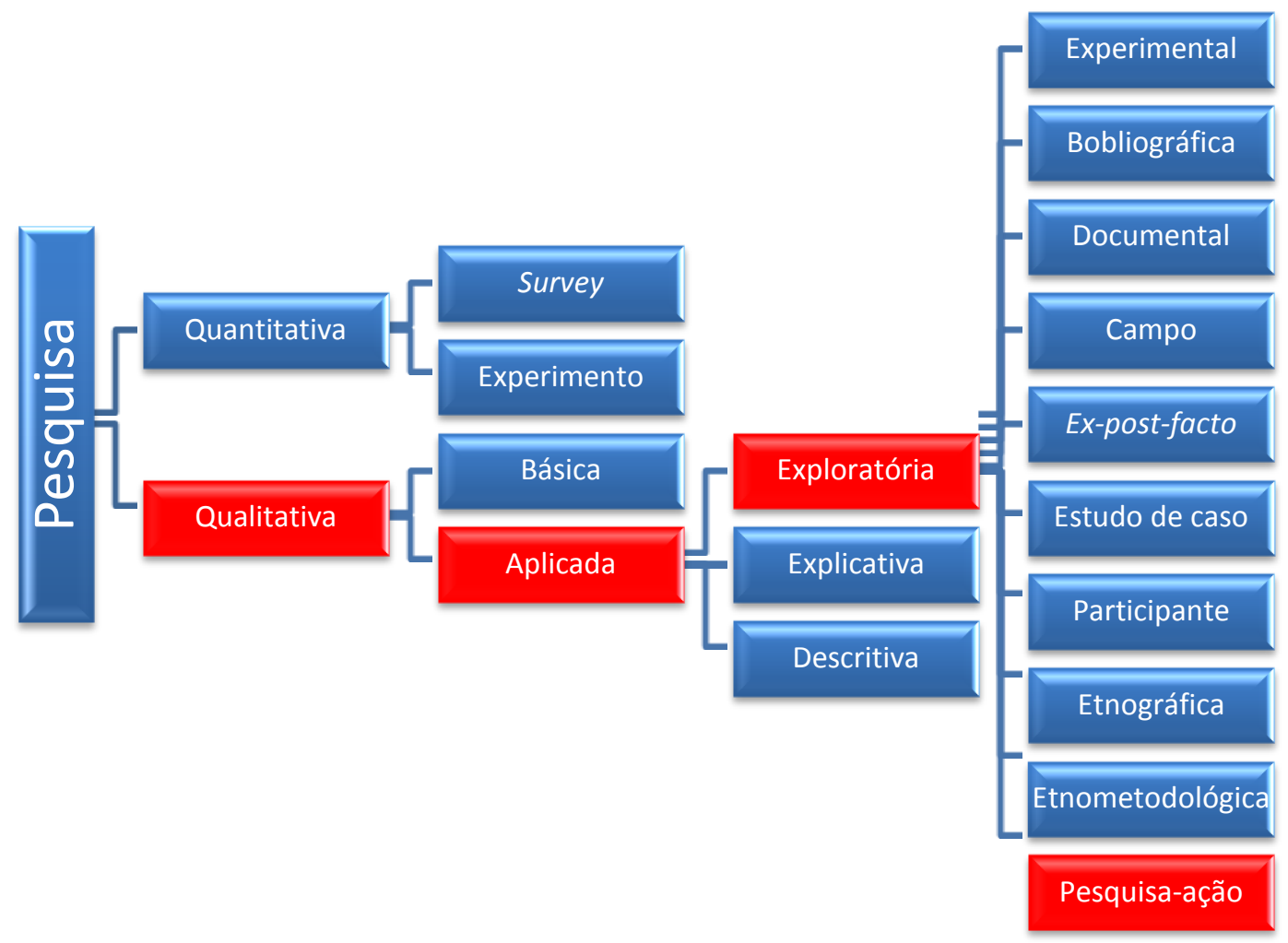

Fonte: Elaborado pelo autor (2017).

Para Thiollent (1996), a pesquisa-ação consiste essencialmente em acoplar pesquisa 
e ação em um único processo, no qual os atores implicados participam, junto com os pesquisadores, para chegarem interativamente a elucidar a realidade em que estão inseridos, identificando problemas coletivos, buscando e experimentando soluções em situação real. Simultaneamente, há produção e uso de conhecimento.

A Pesquisa ação aplicada foi realizada de acordo com as seguintes etapas:

Etapa 1 - identificar ou definir o Problema consiste na tarefa do pesquisador em identificar o problema, para resolver ou perguntas que possam ser respondidas com a pesquisa;

Etapa 2 - o pesquisador deverá realizar uma revisão de literatura em busca de teorias que possam estar alinhadas com fatos relevantes sobre o problema e sirvam para dar suporte à solução do problema, que foi identificado na Etapa 1;

Etapa 3 - desenvolver um plano de ações para solucionar o problema

Etapa 4 - o plano de ação desenvolvido na etapa 3, deve ser aplicado na prática;

Etapa 5 - acompanhar e ficar atento as ações implementadas para saber se os resultados encontrados estão de acordo com o que estava sendo esperado, para resolver o problema apresentado;

Etapa 6 - avaliar os efeitos das ações. Esse é um ponto decisivo. Caso as ações implementadas na etapa 4, não tenham obtido sucesso e o problema não tenha sido resolvido, se faz necessário considerar caminhos alternativos, com a colaboração dos participantes, para resolver o problema;

Etapa 7 - implementar um plano de ações, caso a Etapa 3, precise ser ajustada. Isso deverá ocorrer quanto os resultados obtidos na Etapa 6 não forem eficazes;

Etapa 8 - é a etapa conclusiva dos ciclos da Pesquisa-ação. O problema deverá estar resolvido e os objetivos da pesquisa atingidos com êxito.

A pesquisa deve ser conduzida de modo que não seja predeterminada pelos interesses dominantes que atravessam a organização. De acordo com a ética profissional, há um constante compromisso com a verdade e com a compreensão compartilhada entre os atores que se relacionam na situação investigada. Neste contexto de pesquisa organizacional, o projeto de pesquisa-ação agrega técnicas de pesquisa a serem aplicadas nas organizações. (THIOLLENT, 1997).

A figura 4 apresenta a estrutura da condução da pesquisa-ação. 
Figura 4 - Proposta para Pesquisa - ação

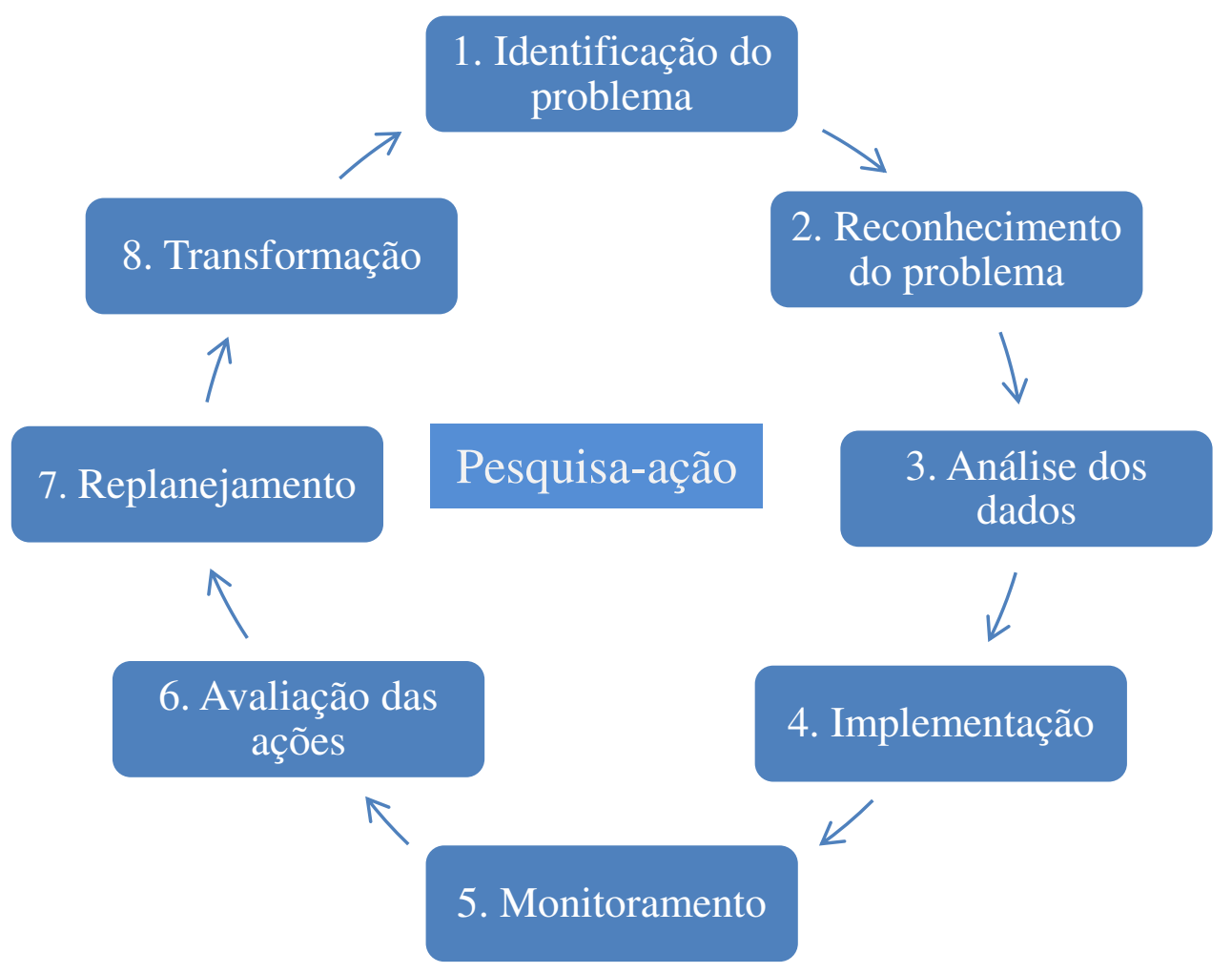

Fonte: Elaborada pelo autor (2017).

O modelo ilustra um exemplo de Pesquisa-ação utilizada no projeto, no entanto é importante ressaltar que esse método é naturalmente dinâmico, interativo e flexível, principalmente pelo seu caráter interativo. É relevante destacar que, embora as etapas possuam uma lógica clara de relacionamento entre elas, na prática podem ocorrer muitas situações em que se faz necessário voltar à etapa anterior para realizar pequenos ajustes antes de avançar.

Num projeto real, o trabalho em grupo proporciona momentos de aprendizagem únicos (CAVALCANTE, 2011). Além do desenvolvimento cognitivo, as competências e habilidades adquiridas nas disciplinas que foram relacionadas diretamente com o projeto, os alunos têm a possibilidade de desenvolver um conjunto de competências transversais, que constituem o grande diferencial na formação, particularmente, por serem alunos da última etapa da educação básica, fornecendo-lhes assim, os meios para progredir no trabalho e em estudos posteriores. A participação neste projeto permite ao aluno um nível mais profundo de entendimento e retenção de informações e o desenvolvimento de competências transversais que devem ser aprofundadas e exploradas, sendo fundamentais em sua futura vida profissional.

Em ciência, busca-se atender os princípios de relevância. Salomon (1991) cita que é 
relevante à ciência aquilo que tem relevância operativa, humana e contemporânea. Na relevância operativa, a solução implica na geração de novos conhecimentos. Na relevância humana, a solução deve ter utilidade para a humanidade. Na relevância contemporânea, refere-se à atualização e à novidade. O Quadro 3 descreve o problema de pesquisa abordado, contemplando estes pontos, propostos por Salomon (1991).

Quadro 3 - Relevância e argumentação

\begin{tabular}{|c|l|}
\hline Relevância & \multicolumn{1}{|c|}{ Argumentação } \\
\hline \multirow{5}{*}{ Operativa } & $\begin{array}{l}\text { O trabalho propõe um método de aplicação da ABP em educação } \\
\text { ambiental, integrando necessidades e tecnologias atuais. Com isso se } \\
\text { disponibiliza conhecimentos que podem subsidiar a prática } \\
\text { profissional e multidisciplinar de interessados em aplicações de } \\
\text { metodologias ativas e inovadoras de ensino e aprendizagem. }\end{array}$ \\
\hline \multirow{5}{*}{ Humana } & $\begin{array}{l}\text { A educação existe para atender necessidades humanas, integrando o } \\
\text { indivíduo à sociedade e fornecendo bases para a construção e } \\
\text { adaptação da realidade em que vive. Quaisquer esforços para sua } \\
\text { melhoria podem propiciar melhores condições de vida para a } \\
\text { sociedade. }\end{array}$ \\
\hline Os profissionais que querem se inserir em uma sociedade, competitiva \\
e globalizada, característica da contemporaneidade, devem agregar em \\
sua estratégia melhorias no processo de ensino e aprendizagem. A \\
integração da ABP com as disciplinas do currículo acompanha \\
tendências modernas é extremamente necessária, além da melhoria na \\
qualidade de ensino.
\end{tabular}

Fonte: Elaborado pelo Autor (2017)

Sob o termo de cobertura método científico, podem-se identificar três conceitos básicos fundamentais complementares, mas distintos, com implicações diretas no processo de realização de ciência. O primeiro conceito diz respeito ao que está sendo chamada nesse trabalho de método de abordagem, abordagem metodológica mais abstrata e ampla na investigação dos acontecimentos naturais/sociais (LAKATOS; MARCONI, 2006). O segundo conceito se refere ao método de procedimento, abordagem metodológica aplicada nas etapas mais concretas do estudo, e mais restritas em termos de sua explicação (LAKATOS; MARCONI, 2004). O terceiro conceito é o método de investigação, abordagem metodológica aplicada à prática da pesquisa e ao modo de intervenção do pesquisador na realidade (VERGARA, 2005).

Como método de procedimento, ele se apoia no estruturalismo, que analisa um acontecimento concreto, gera um modelo abstrato que retrata o objeto estudado, e volta ao concreto, numa realidade estruturada da experiência dos sujeitos sociais (KAUFMANN, 1997). Como método de investigação, ele lança mão da pesquisa-ação, no qual pesquisador 
e sujeitos representativos do problema decidem, empiricamente, envolver-se de modo cooperativo e participativo (THIOLLENT, 1996). Em todas as escolhas, a razão de sua opção se deu em função das semelhanças na orientação filosófica e na abordagem prática percebida nos métodos em relação às que se pretendia imprimir na condução deste estudo.

Como abordagem prática, por um lado, acredita-se que, como no estruturalismo, toda análise de acontecimentos deve não só conhecer seus elementos, mas desvendar suas inter- relações, explicando tanto sua totalidade, como aparentes variabilidades (LEVEY e GREENHALL, 1987). Por outro lado, acredita-se na real possibilidade das atividades colaborativas e participativas entre pesquisadores e sujeitos para a solução de problemas, característicos da aplicação da pesquisa-ação (THIOLLENT, 1996).

Todo esse conceito de pesquisa é então sintetizado no Quadro 4.

Quadro 4 - Síntese da Metodologia de Pesquisa.

\begin{tabular}{|c|c|}
\hline Elementos da Pesquisa & Forma de Aplicação \\
\hline Método & Pesquisa experimental; Pesquisa-ação. \\
\hline Técnica de Coleta & Entrevistas, Observação Direta e Indireta. \\
\hline Estudo & Descritivo \\
\hline Finalidade & Operacional voltada para fins práticos \\
\hline Abordagem Adotada & Interdisciplinares \\
\hline Campos do Conhecimento & Relatos e / ou Fatos \\
\hline Natureza dos Dados & Primários e Secundários \\
\hline Origem dos Dados &
\end{tabular}

Fonte: Elaborado pelo autor (2017).

A partir de uma população composta por alunos do Ensino Fundamental do Ciclo II e do Ensino Médio, de uma escola da rede pública da cidade de Lorena, Estado de São Paulo, a unidade de análise foi constituída pela união de duas turmas, sendo um conjunto de vinte e oito alunos do nono ano e trinta alunos do primeiro ano. A escolha da unidade de análise foi decidida por possibilitar a aplicação do método junto a alunos da própria pesquisadora, que de modo geral, não têm somente na pesquisa o principal instrumento de busca de melhorias. Esse trabalho pode enriquecer o conteúdo de sala de aula, por diversificar a metodologia de ensino aprendizagem já utilizado junto a alunos dessa unidade escolar.

Sendo o objeto de estudo desse trabalho, a variável da pesquisa foi aplicação do método de Aprendizagem Baseada em Projetos na percepção dos alunos quanto à dinâmica 
do método. As atividades interdisciplinares do projeto foram desenvolvidas ao longo de doze meses, tempo necessário para aplicação do conteúdo das disciplinas do currículo e da aplicação da ABP.

A pesquisa apresentada nesse trabalho está dividida em duas situações: a primeira teve por objetivo, levantar dados e informações necessárias relacionadas à ABP e suas práticas. A segunda, o desenvolvimento de um método com aplicação por meio da pesquisa-ação, análise, considerações e conclusões. Ao traçar de modo ordenado e dispor em sistema a forma de proceder de um pesquisador para alcançar um objetivo ao longo de um percurso, o método científico constitui o roteiro básico da pesquisa acadêmica (FERRARI, 1982).

Assim, para assegurar a qualidade e a fidedignidade do conhecimento gerado nesse estudo, foram seguidas as etapas do método científico (BUNGE, 1980) apresentadas na Figura 5.

Figura 5 - Etapas da Pesquisa

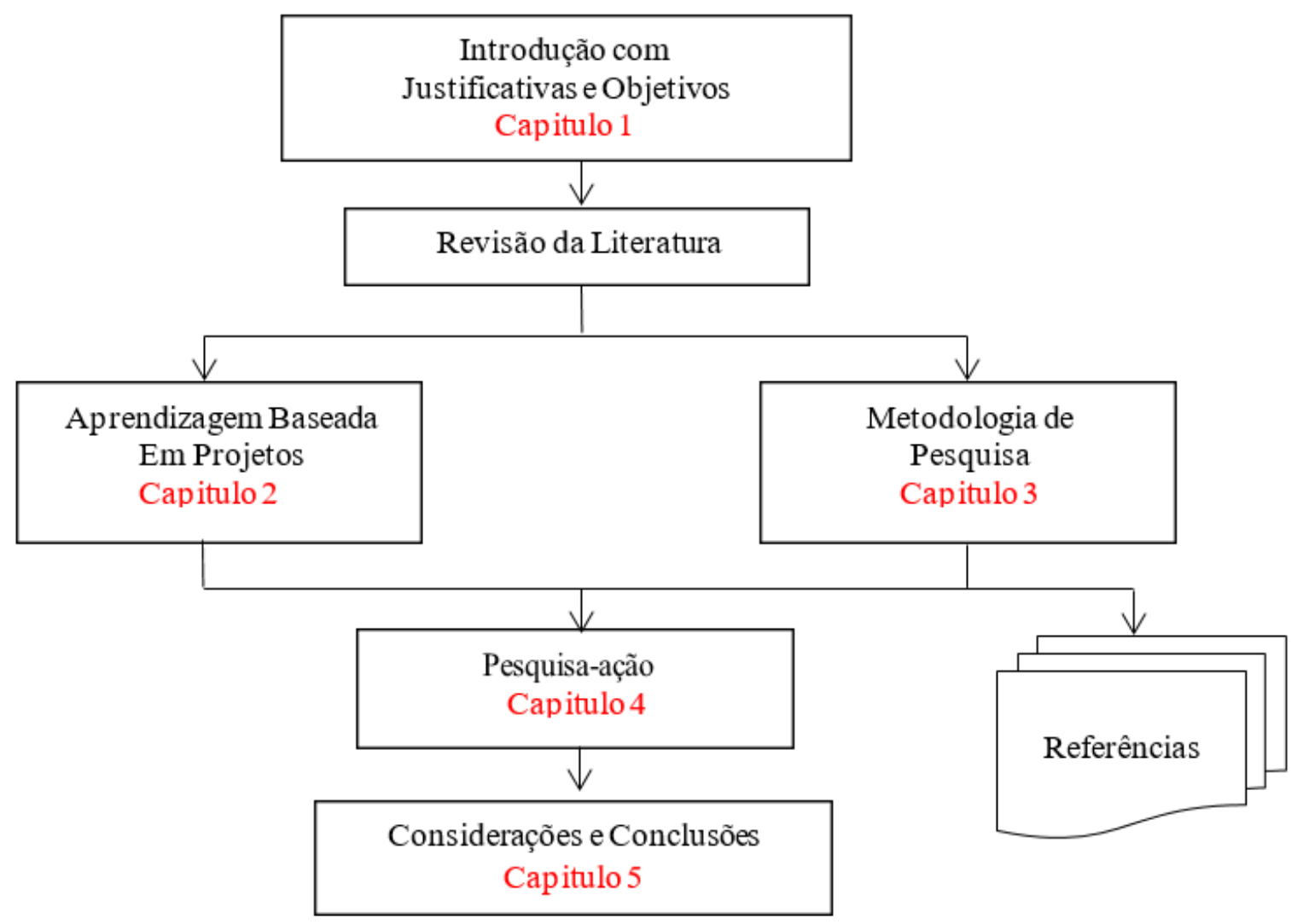

Fonte: Elaborado pelo Autor (2017).

Os principais instrumentos dessa pesquisa se dão por meio de coleta de dados por questionários aplicados aos alunos participantes, após os mesmos serem submetidos ao 
método e a metodologia de avaliação desenvolvida. A distribuição das questões do questionário é dividida em: Propostas relativas ao método (concordar ou discordar, total ou parcial); Múltipla escolha (no qual escolhe apenas uma opção); Avaliação do método (critério de 0 a 10); Pergunta aberta (contribuição dissertativa). 


\section{O MÉTODO APLICADO}

\subsection{A Escola}

A escola onde a pesquisa foi aplicada é mantida pela Secretaria da Educação do Estado de São Paulo, é uma instituição de Ensino Fundamental e Ensino Médio, autorizada a funcionar no período da manhã, o Ensino Médio, do $1^{\circ}$ ao $3^{\circ}$ ano, recebe alunos do entorno da escola. No período da tarde o Ensino Fundamental. Para esse trabalho foram selecionadas duas turmas, uma do ensino médio e outra do ensino fundamental.

\subsection{Grupo Tutorial}

Na implantação de uma metodologia baseada em projetos, o primeiro passo foi à definição de um grupo tutorial, composto por:

- Docente - Tem como princípio o domínio do conteúdo a ser aplicado, além de conhecer as etapas necessárias para a implementação do método baseado em projetos. Nesse trabalho, quem assumiu o papel foi o próprio pesquisador, que expôs toda a ementa e projeto aos alunos e foi responsável em garantir o funcionamento do grupo e das discussões. $\mathrm{O}$ docente nessa metodologia tem um perfil diferente do já conhecido modelo tradicional, ou seja, deixa de ser o transmissor do saber e passa a ser um motivador e parceiro do aluno na descoberta do conhecimento. O docente estimula a reflexão a partir de diferentes pontos de vista, a fim de que os objetivos estabelecidos para o projeto possam ser alcançados. Em suma, orienta os alunos a atingirem os objetivos principais do projeto: aprender a fazer um exame analítico e minucioso de um problema, identificar os objetivos de aprendizagem, buscar as informações relevantes e aprender a trabalhar em grupo.

- Monitor - Foi selecionado um aluno do ensino médio para auxiliar na condução do projeto, em especial na parte prática fora da sala de aula. O projeto de iniciação científica foi denominado Educação Ambiental Baseada em Projetos: uma Aplicação no Ensino Médio e Ensino Fundamental, pois esta temática foi integrada a atividade.

- Grupos de Trabalho - Composto por 4 a 5 alunos, tendo um Coordenador de Grupo, responsável por garantir que a discussão do problema se dê de forma metódica e todos os membros participem da discussão, e de um Secretário do Grupo, responsável pelas anotações de todas as atividades realizadas. Este último garante a organização das mesmas, respeitando as diretrizes do coordenador do grupo. Os papéis de coordenador 
e de secretário foram assumidos por todos os alunos em forma de revezamento. $\mathrm{O}$ líder possui como atribuições, entre outras que lhe forem delegadas pelo grupo, a de ser o contato da equipe com o professor e a de agendar reuniões do grupo. $\mathrm{O}$ secretário é o responsável pelo Diário de Bordo da Equipe de Projeto que consiste nas Atas de Reunião da equipe, em que devem ser registradas todas as ações desenvolvidas pela equipe durante a execução do projeto.

- Padrinho - O padrinho é um aluno veterano do curso ou outro professor ligado a este. Ele tem por objetivo dar apoio permanente nas dificuldades operacionais típicas da execução de um projeto. Seu papel não é técnico, mas sim de apoio às equipes em questões práticas que surgem no dia a dia de um projeto, em função de sua maior inserção na comunidade acadêmica há mais tempo.

\subsection{Projeto}

É o elemento central da metodologia, em que as propostas de desafio acontecem. Buscou-se ser simples e objetivo para visualizar a proposta principal, além de motivador para uma discussão entre os alunos. Cada equipe foi orientada a usar em seu projeto pelo menos um protocolo de comunicação entre seus membros (Facebook ou Whatsapp). Essas comunicações foram registradas no Diário de Bordo do secretário e puderam ser auditadas a qualquer momento pelo docente.

No início das aulas, foi apresentado para os alunos o método ABP, com foco no meio ambiente, colocando para eles um desafio, que seria aplicar a metodologia aprendida em um problema atual vivido pela sociedade: a reutilização e desperdício da água. Em discussão com os alunos a temática reuso e economia de água foi proposta, aceita por unanimidade. A partir disso discutiram-se quais as formas de reuso e economia de água na tentativa de colaborar com a preservação do meio ambiente e sociedade. A especificação cisternas para a captação de água de chuva é então levantada pelos alunos e aprovada como temática principal do projeto. A especificação então se dá em: "Desenvolvimento de um Sistema de Captação das Águas de Chuvas, para fỉm não potável nas dependências da escola". Os alunos através do Projeto deveriam oferecer pelo menos, uma solução concreta para o tema proposto. O Projeto mesmo que em uma temática definida, não possui solução única. Ele é desafiador para alunos e docentes. Os objetivos estão relacionados em:

- apresentar o macro processo do tema selecionado;

- apresentar a especificação técnica de cada etapa;

- apresentar um projeto e suas especificações relacionadas à interdisciplinaridade 
(Física, Geografia, História, Matemática, Arte e Língua Portuguesa);

- construir protótipos do projeto.

Uma das fases do projeto que é fundamental para esse tipo de aprendizagem é a construção de protótipos, que tem como tarefa testar forma e função. Nessa etapa, os alunos construíram maquetes que permitiram ter uma visão tridimensional e o desenvolver o conhecimento cognitivo. Esse momento foi muito importante para o processo de ensinoaprendizagem, pois proporcionou um contato efetivo entre o aprendiz e o objeto de estudo através da experiência da manufatura e da experiência tridimensional concreta. Como o objetivo foi que todos os alunos construíssem seus modelos, pretendia-se utilizar material reciclado ou de baixo custo, que fosse de fácil manuseio, sem necessidade de um treinamento especializado. Todos os grupos realizaram a demonstração do protótipo no dia e local estipulado pelo professor. O protótipo ficará guardado na unidade escolar para exposições futuras.

\subsection{Recursos de Aprendizado}

Os recursos utilizados no projeto foram:

- recursos Materiais: caderno, papel sulfite, canetas, cartolinas, papel vegetal, régua, folha de seda, lápis, borracha, lápis de cor, cola e tesoura;

- recursos espaciais: anfiteatro da escola, sala de leitura, sala multimídias;

- recursos tecnológicos: celulares, computadores e tablete;

- recursos Humanos: profissionais da educação, alunos, pais, estagiários e voluntários.

\subsection{O Projeto e a Interdisciplinaridade}

As disciplinas envolvidas no projeto apresentam uma carga horária semanal de 2 horas/aula, exceto Matemática e Língua Portuguesa, que variam de 5 a 6 aulas semanais. Cada hora/aula equivale a 50 minutos, totalizando 1.200 horas anuais de estudo. A equipe de professores participantes do projeto estabeleceu uma parceria de colaboração e responsabilidade desenvolvendo uma possibilidade de mudanças. Eles também se sentiram motivados para discutir a explorar novas práticas pedagógicas. A abordagem interdisciplinar possibilitou ao aluno durante algumas dessas aulas, construir o próprio conhecimento e aplicá-lo em situações diversas. Trabalhar o currículo de forma dinâmica e atraente e não mais fragmentada e/ou cristalizada, fará com que o aluno alcance os objetivos propostos pelas disciplinas. Por meio da interdisciplinaridade, as disciplinas são 
integradas facilitando a aprendizagem do educando.

Para a aplicação desta pesquisa, duas turmas foram acompanhadas, durante o ano letivo de 2015 e 2016. O cronograma desenvolvido pelo método proposto é apresentado no Quadro 5.

Quadro 5 - Cronograma da Disciplina

\begin{tabular}{|c|c|c|}
\hline Semana & Conteúdo Teórico & Conteúdo Prático \\
\hline 1 & Introdução a Educação Ambiental & Discussão sobre a importância \\
\hline 2 & Aplicações da Educação Ambiental & Construção de Gráfico \\
\hline 3 & Apresentação da ABP e Projetos & Divisão de grupos e regras \\
\hline 4 & Projeto por Canvas & Etapas do Projeto \\
\hline 5 & Investigação de Problemas Ambientais & Quadra da Escola \\
\hline 6 & Confecção do Pluviômetro & Exercícios em Sala \\
\hline 7 & Cálculo com Voltímetro & Exercícios no laboratório \\
\hline 8 & Princípios Físicos - Leis de Faraday & Exercícios no Laboratório \\
\hline 9 & Atividade em grupo & Construção da Horta Escolar \\
\hline 10 & Atividade em Grupo & Construção da Horta Escolar \\
\hline 11 & Avaliação Prática & Horta Escolar \\
\hline 12 & Atividade em grupo & Sala de Aula \\
\hline 13 & Alimentos- Merenda Escolar & Exercícios em Sala \\
\hline 14 & Escalas e legenda & Exercícios em Sala \\
\hline 15 & Atividade em Grupo & Exercícios em Sala \\
\hline 16 & Projeções & Exercícios em Sala \\
\hline 17 & Tabelas e Gráficos. & Exercícios em Sala \\
\hline 18 & Avaliação Teórica e Entrega do Projeto & Exercícios no Pátio da Escola \\
\hline 19 & Protótipo da Cisterna & Exercícios no Pátio da Escola \\
\hline 20 & Releitura Obras de Arte & Oficina de Arte \\
\hline 21 & Leitura de Imagens & Oficina de Arte \\
\hline 22 & Água Virtual & Oficina de Arte \\
\hline 23 & Sugestões para o Blog & Sala de Informática da Escola \\
\hline 24 & Avaliação Teórica & Entrega dos Projetos em Desenho Manual \\
\hline 25 & Avaliação Prática & Exercícios em Laboratório \\
\hline 26 & Construção do Blog & Aula prática na Sala de Informática \\
\hline
\end{tabular}


(conclusão) Quadro 6 - Cronograma da Disciplina.

\begin{tabular}{|c|c|c|}
\hline Semana & Conteúdo Teórico & Conteúdo Prático \\
\hline 27 & Construção do Blog & Aula prática na Sala de Informática \\
\hline 28 & Construção do Blog & Aula prática na Sala de Informática \\
\hline 29 & Apresentação dos Grupos & Aula prática na Sala de Aula \\
\hline 30 & Modelos e Maquetes em Projetos & Confecções de maquetes \\
\hline 31 & Avaliação- Maquetes & $\begin{array}{l}\text { Atividade Prática para a construção das } \\
\text { maquetes e encerramento do projeto }\end{array}$ \\
\hline 32 & Construção de uma casa & Energia e Consumo \\
\hline 33 & Aplicação de Conceitos Físicos & Exercícios sobre Circuito Elétrico \\
\hline 34 & Relatório Final & $\begin{array}{c}\text { Discussão sobre Análise de Falhas em } \\
\text { Projetos }\end{array}$ \\
\hline 35 & Relatório Final & $\begin{array}{c}\text { Apresentação dos Projetos e Maquetes na } \\
\text { Sala de Aula }\end{array}$ \\
\hline 36 & Feira de Ciências & $\begin{array}{c}\text { Apresentação das Maquetes na Feira de } \\
\text { Ciências na Unidade Escolar }\end{array}$ \\
\hline 37 & Avaliação Dissertativa & $\begin{array}{c}\text { Orientações quanto os projetos - O que } \\
\text { foi prescrito x o que foi real }\end{array}$ \\
\hline 38 & Avaliação Objetiva & $\begin{array}{l}\text { Apresentação dos Relatórios Finais dos } \\
\text { Projetos - } 10 \text { minutos por grupo }\end{array}$ \\
\hline 39 & Avaliação Final e Sugestões & $\begin{array}{l}\text { Apresentação dos Relatórios Finais dos } \\
\text { Projetos - } 10 \text { minutos por grupo }\end{array}$ \\
\hline 40 & Implantação da Cisterna e Avaliação & $\begin{array}{c}\text { Encerramento da Disciplina - Relatos e } \\
\text { discussões sobre o aprendizado }\end{array}$ \\
\hline
\end{tabular}

Fonte: Próprio Autor (2017).

\subsection{Sequência Didática}

Entender o projeto, formular hipóteses e objetivos, mostram as habilidades desenvolvidas pelos alunos. O trabalho em equipe foi de fundamental importância nesse momento, pois o grupo definiu as prioridades para a elaboração do projeto. A cada semana houve a apresentação de um tema com atividades práticas e/ ou teóricas, distribuídas da seguinte forma:

- Semana 1: Introdução ao assunto Educação Ambiental. Os alunos se reuniram na sala de leitura da escola e foram divididos em 10 grupos de 5 e 2 grupos de 4 alunos, um aluno 
de cada grupos ficou responsável pela função de líder e outro de secretário, os outros componentes dos grupos foram colaboradores. Quanto às especificidades do $1^{\circ}$ ano, as habilidades foram trabalhadas contemplando os níveis de proficiência exigidos para o Ensino Médio. As duas turmas foram trabalhadas simultaneamente quando as habilidades eram comuns para os dois níveis de ensino.

Foi feita uma apresentação prévia dos alunos sobre o tema proposto (água), como um recurso utilizado desde a antiguidade até os dias atuais. Os alunos foram encorajados apresentar suas considerações de forma oral e escrita, do bom e mau uso da água, destacando a importância nos cuidados. Isso é demonstrado nas Figuras 6 e 7.

Figura 6 - Grupos em Desenvolvimento

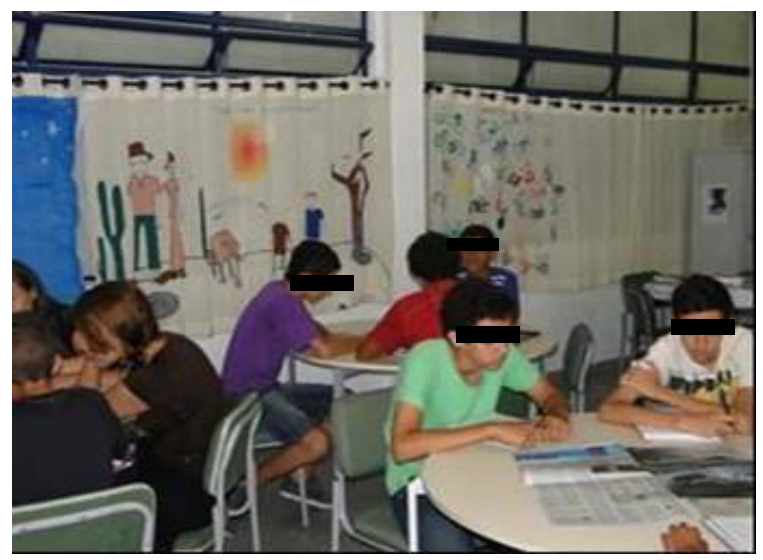

Fonte: Próprio Autor.
Figura 7 - Orientação dos Docentes aos Grupos

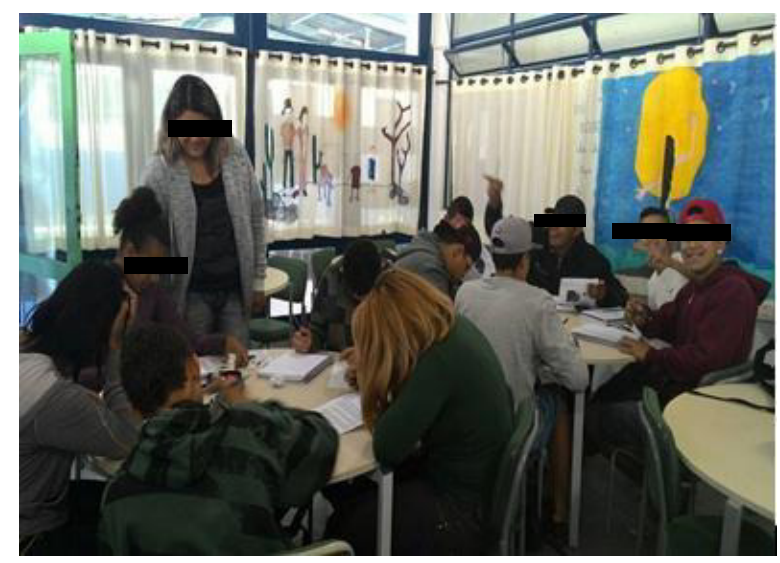

Fonte: Próprio Autor.

- Semana 2 - Aplicação da Educação Ambiental: por meio de análise do consumo de energia das residências dos alunos, eles construíram gráficos de barra na disciplina de matemática. Conforme evidenciado nas Figuras 8 e 9.

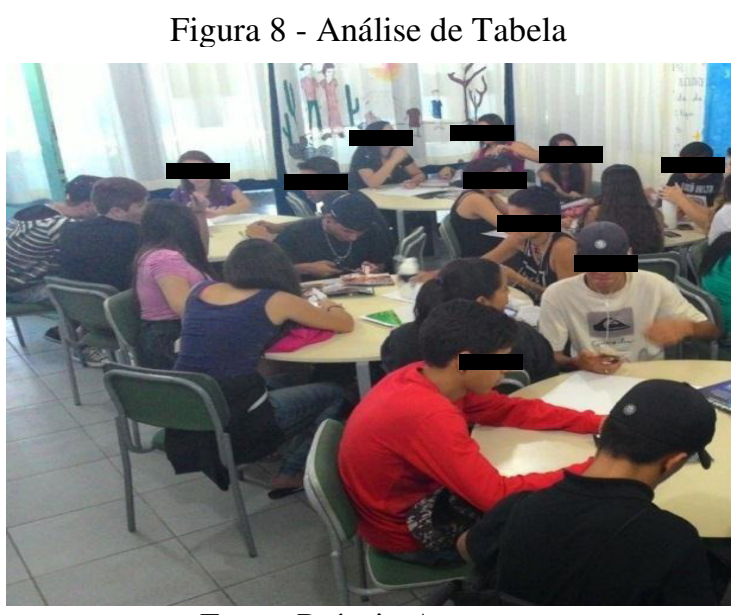

Fonte: Próprio Autor.
Figura 9 - Construção de Gráficos

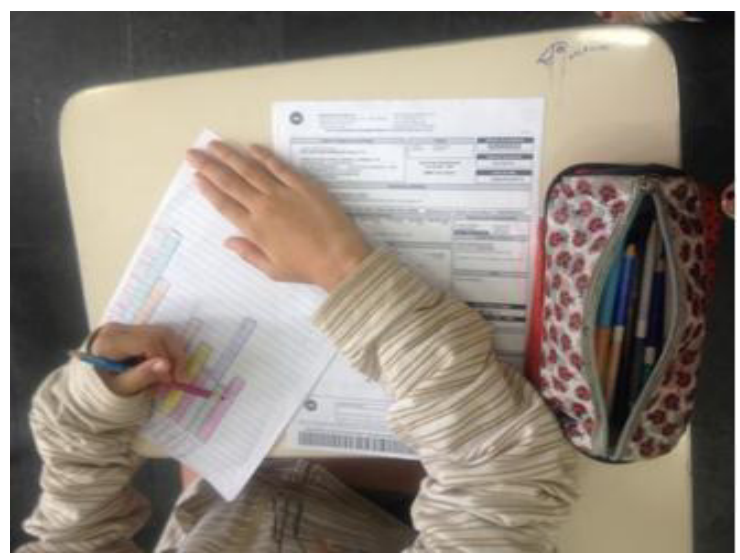

Fonte: Próprio Autor. 
- Semana 3 - A metodologia da ABP foi apresentada com destaque, mostrando sua importância no processo de ensino e aprendizagem. Os alunos se reuniram na Sala de Informática fizeram uma pesquisa sobre os temas relevantes: ABP, Educação Ambiental, Meio Ambiente, Sustentabilidade, Racionamento da água e Captação das águas pluviais. As respostas dos alunos foram registradas na lousa e discutidas pela turma. Os grupos firmaram um acordo de colaboração e comprometimento entre as equipes envolvidas para execução das atividades. Cada grupo recebeu uma prancheta e percorreram os arredores da escola buscando possíveis situações problemas. Conforme é demonstrado nas Figuras 10 e 11.

Figura 10 - Atividades na Sala de Informática

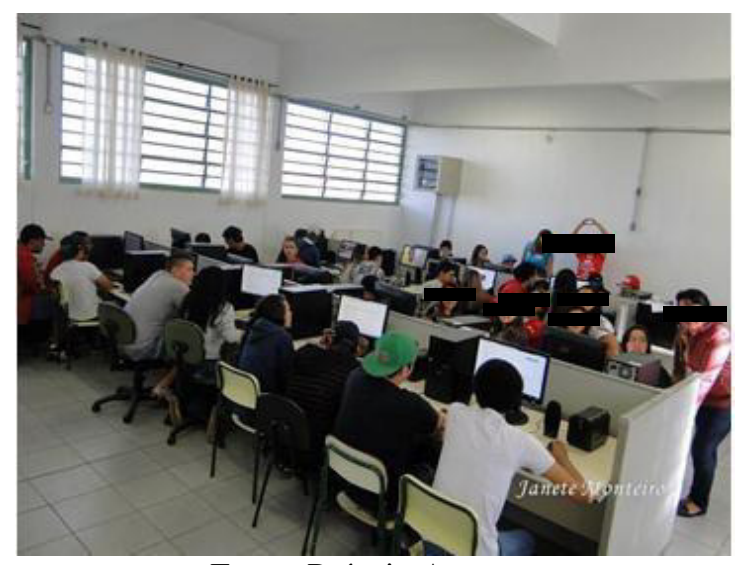

Fonte: Próprio Autor.
Figura 11 - Levantamento dos Problemas

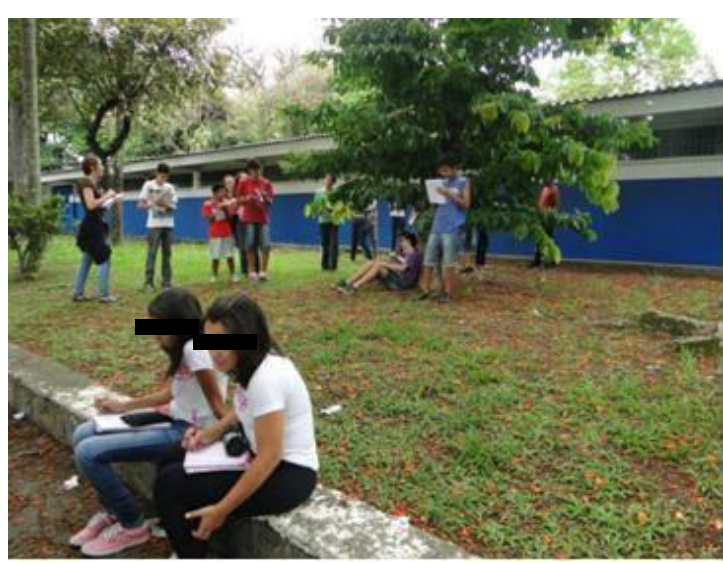

Fonte: Próprio Autor.

- $\quad$ Semana 4 - O Modelo PMC - Project Model Canvas (FINOCCHIO JUNIOR, 2013) foi apresentado como modelo de projeto e os alunos tiveram a missão de inserir as etapas do projeto do grupo no modelo. O prazo foi de 5 semanas, conforme Figuras 12 e 13.

Figura 12 - Modelo PMC

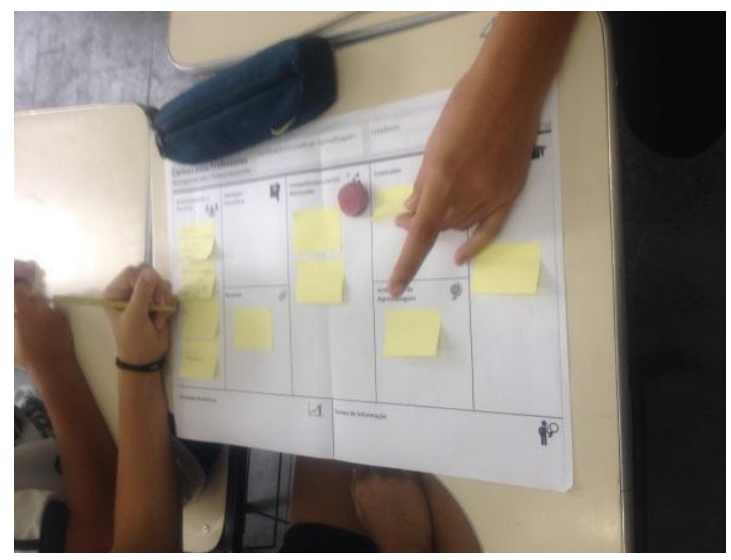

Fonte: Próprio Autor.
Figura 13 - Discussão sobre o Projeto

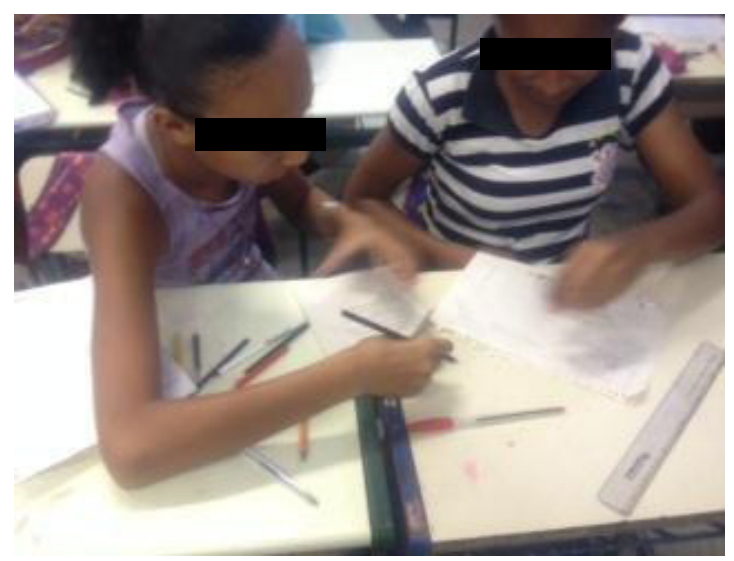

Fonte: Próprio Autor. 
- Semana 5 - Os grupos de alunos se reuniram num ambiente descontraído (quadra da escola) e discutiram os problemas levantados e possíveis soluções a médio e longo prazo. Cada grupo fez uma apresentação oral, que foi registrada pelo secretário de cada grupo, demonstrado nas Figuras 14 e 15.

Figura 14 - Discussão dos Problemas

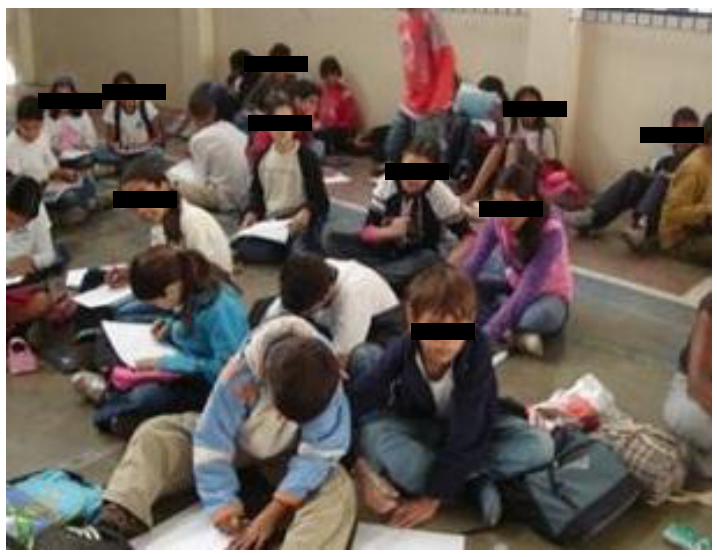

Fonte: Próprio Autor.
Figura 15 - Registro das Soluções

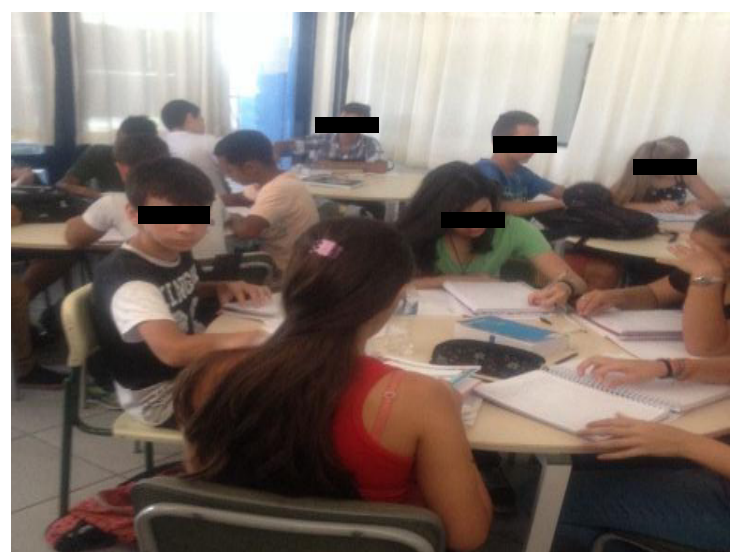

Fonte: Próprio Autor.

- Semana 6 - foram realizadas construções de pluviômetros em sala de aula com material reciclado. O objetivo dessa atividade foi contribuir para uma maior percepção ambiental ao realizar um monitoramento das águas das chuvas, durante dez dias. As precipitações pluviométricas foram registradas para um controle melhor da quantidade de chuva coletada. O pluviômetro foi instalado na casa do aluno e os dados coletados foram tabelados e representados por meio de gráficos. Os alunos passaram a ter uma noção de tempo e clima, os cálculos foram realizados nas aulas de matemática, onde foi necessária uma revisão do conteúdo de transformação de unidades de medida. Há evidências nas Figuras: 16, 17, 18 e 19.

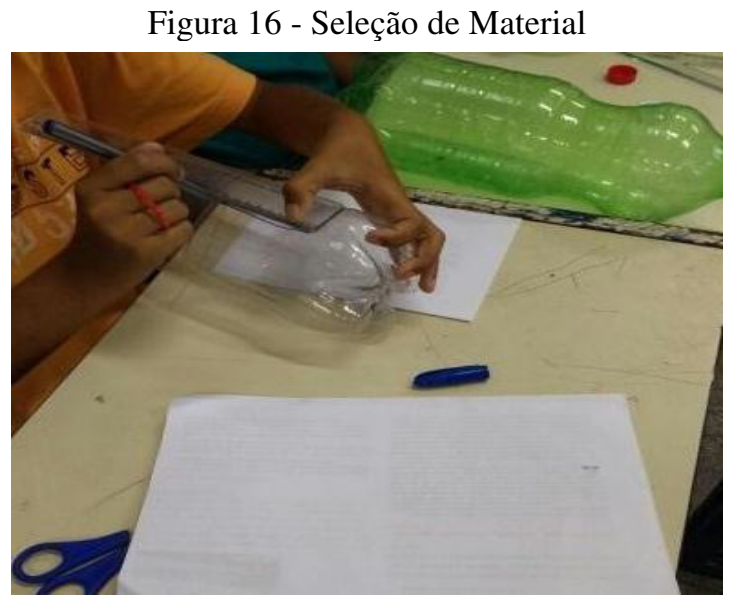

Fonte: Próprio Autor.
Figura 17 - Construção do Pluviômetro

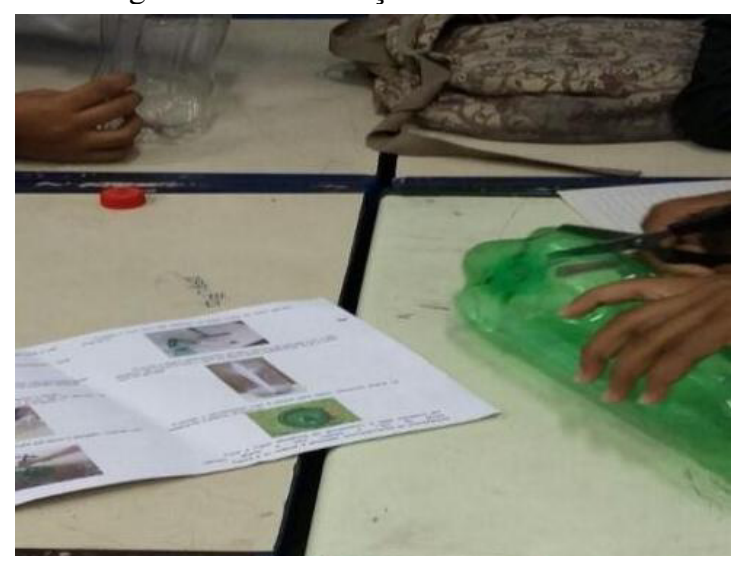

Fonte: Próprio Autor. 
Figura 18 - Marcação de Escala de Medição

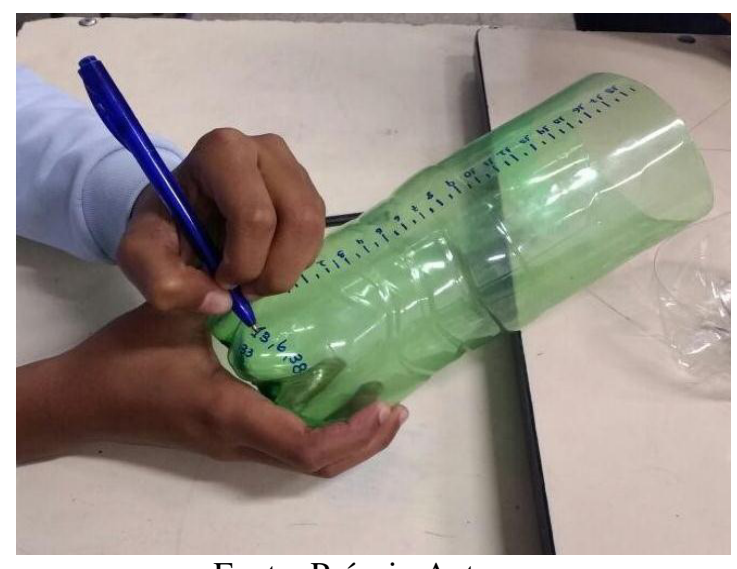

Fonte: Próprio Autor.
Figura 19 - Experimento Construído

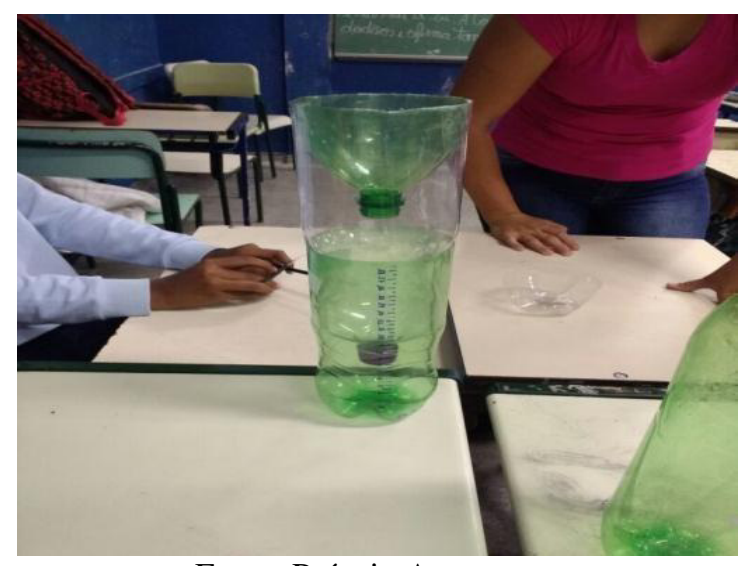

Fonte: Próprio Autor.

- Semanas 7 e 8 - Conceitos Físicos aplicados por meio de energia eólica foram apresentados. Os alunos receberam a proposta de escolherem e construírem um experimento que produzisse uma fonte não poluente de energia, usando material reciclado ou de baixo custo. Por unanimidade a energia eólica foi à escolhida. Essa atividade teve o objetivo de desenvolver a alfabetização científ ica nos alunos do Ensino Médio, proporcionando aos educandos maior tempo de estudo, permitindo que os conceitos físicos passassem a ser analisados e interpretados com mais profundidade. Nas aulas de Geografia, ocorreram debates em torno das principais formas de geração de energia eólica, por meio da construção de experimentos usando a técnica de projetos. Nas aulas de Física os alunos observaram o experimento, elaboraram hipóteses, interpretaram resultados que envolviam interação entre corrente elétrica e campo magnético, resolvendo situações problemas. A construção e o teste do protótipo foram realizados no laboratório e a verificação da coleta de dados foi obtida com voltímetro, onde os mesmos puderam concluir que o cooler gerava energia diferente, embora fossem de 12 watts. Essas etapas são demonstradas nas Figuras $20,21,22$ e 23. 
Figura 20 - Bancada de Construção

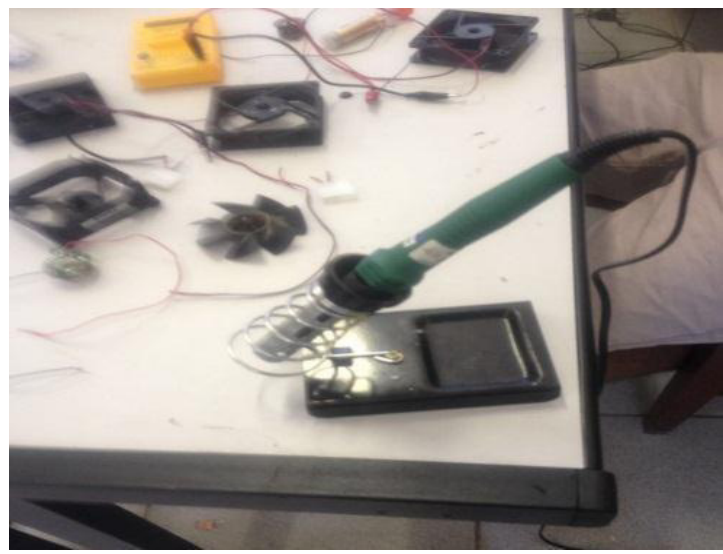

Fonte: Próprio Autor.

Figura 22 - Construção do Protótipo

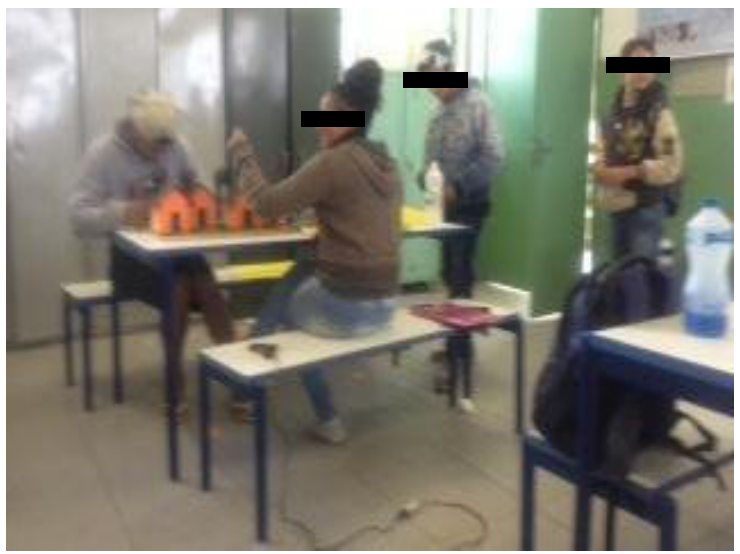

Fonte: Próprio Autor.
Figura 21 -Cooler em Teste

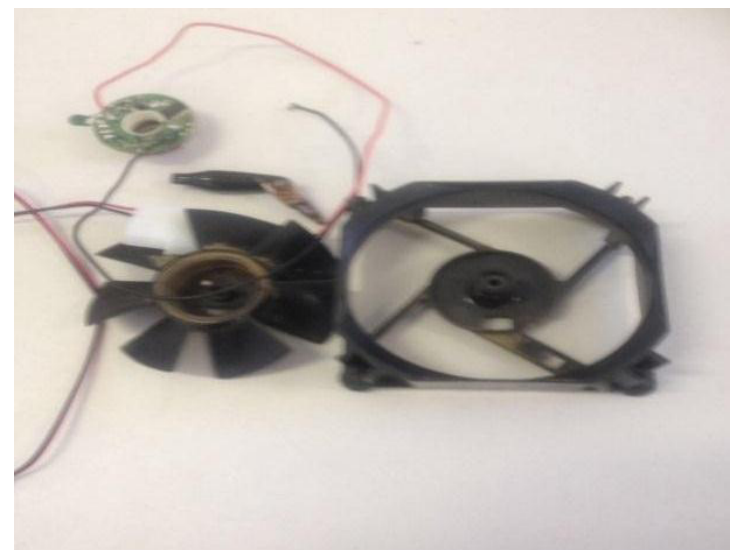

Fonte: Próprio Autor.

Figura 23 - Maquete Construída

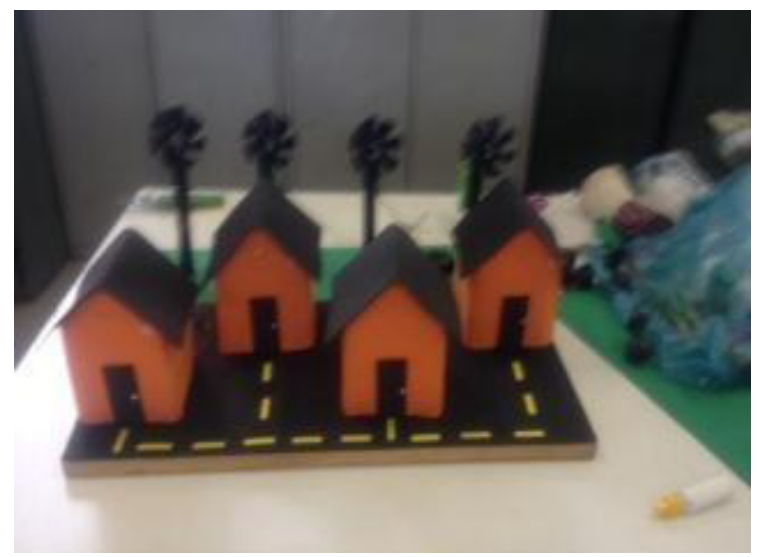

Fonte: Próprio Autor.

- Semanas 9 a 13 - Avaliação Prática: Criação de uma horta escolar: A horta escolar foi criada pelos alunos do Ensino Fundamental em parceria com o grupo Flor de Lis Universidade de São Paulo (alunos de graduação voluntários em projeto social aplicado a Educação Ambiental). A atividade teve como objetivo produzir alimentos para a merenda escolar, hortaliças, ervas medicinais e cultivo de mudas de plantas para o reflorestamento de áreas que estão degradadas, sendo esse um ambiente sustentável que estimule a valorização da dimensão educacional, conforme demonstra as Figuras 24 e 25. 
Figura 24 - Trabalho de campo

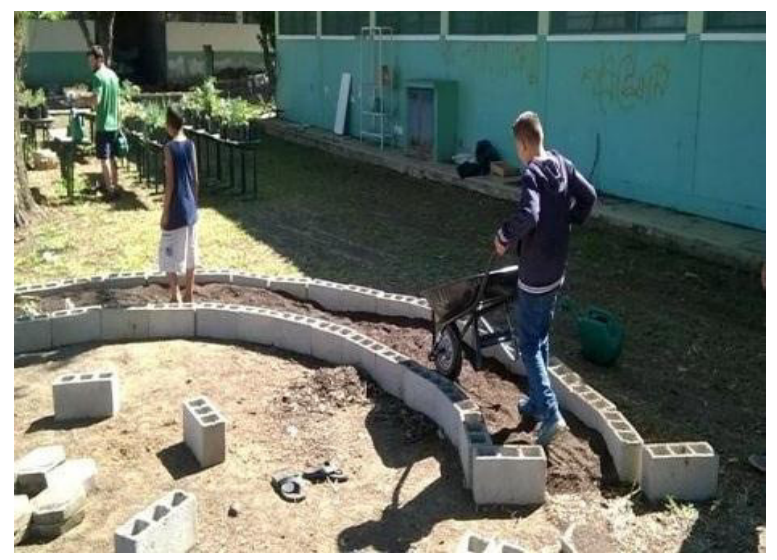

Fonte: Próprio Autor.
Figura 25 - Cultivo da Horta

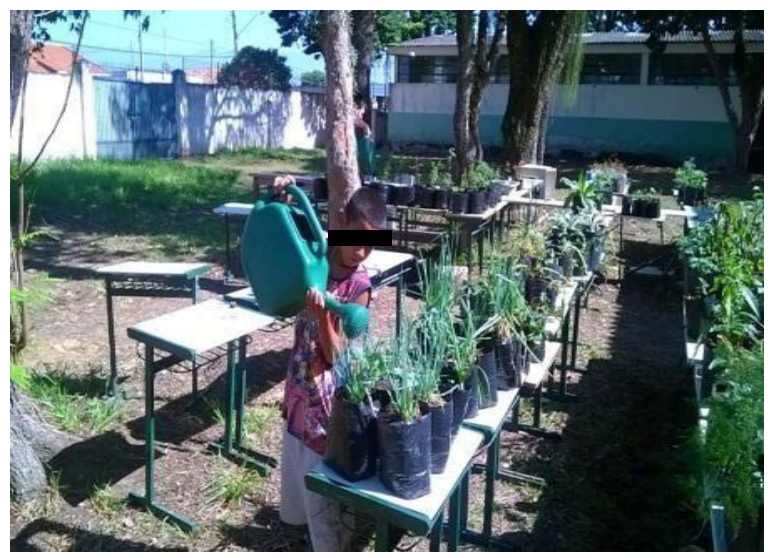

Fonte: Próprio Autor.

- Semanas 14 a 17 - Conteúdo Teórico com escalas, legendas, projeções, leitura e gráficos. A atividade contemplada no caderno do aluno na disciplina de Geografia (Primeiro ano do Ensino Médio) de acordo com a Proposta Curricular do Estado de São Paulo, a partir da página 10 possibilitou o desenvolvimento de atividades entrelaçadas ao projeto, o que pode ser observado nas Figuras 26 e 27.

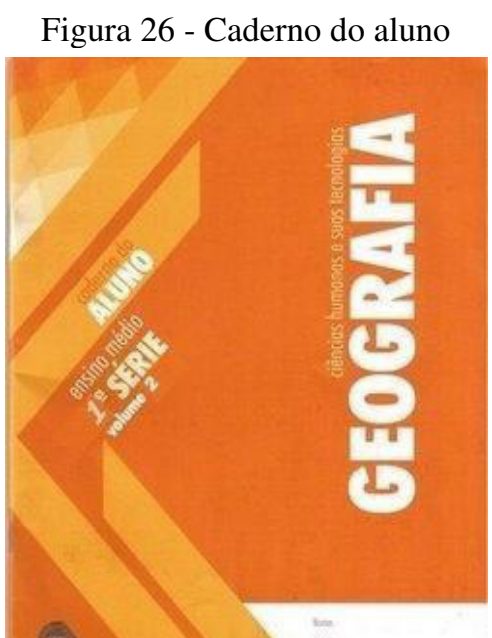

Fonte: Próprio Autor.
Figura 27 - Devolutiva em Sala

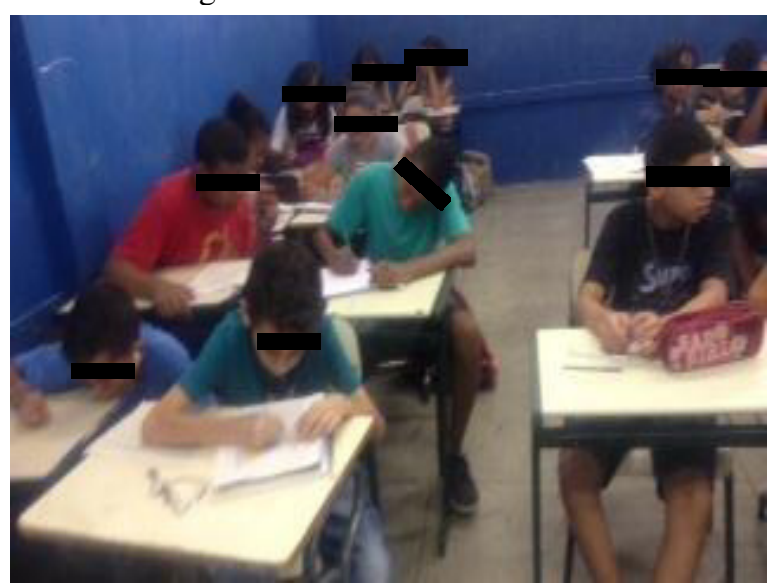

Fonte: Próprio Autor.

- Semanas 18 e 19 - Foi realizada Avaliação Teórica e Entrega dos Projetos. Foi desenvolvido por meio de um seminário, onde os grupos apresentaram questões importantes relacionadas ao meio ambiente. Nessas aulas os alunos também elaboraram o desenho manual das partes que vão compor o projeto da cisterna, as Figuras 28 e 29 evidenciam essa prática. 
Figura 28 - Desenho da Planta da Escola

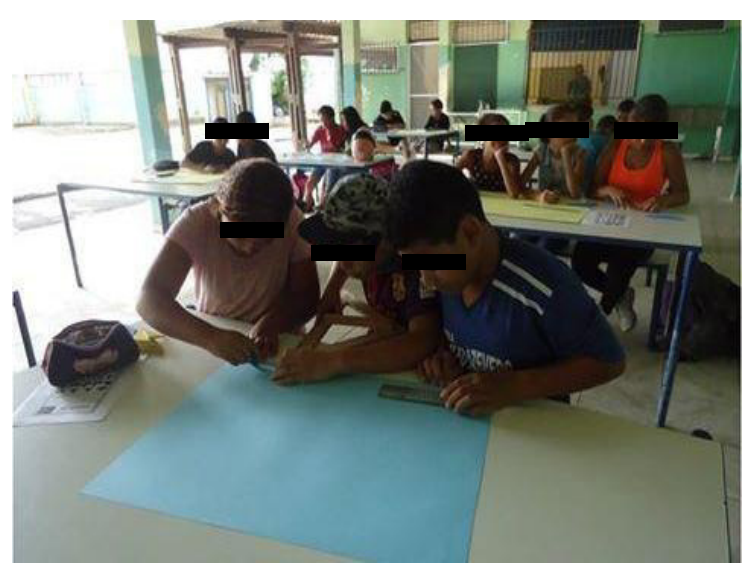

Fonte: Próprio Autor.
Figura 29 - Croqui da Cisterna

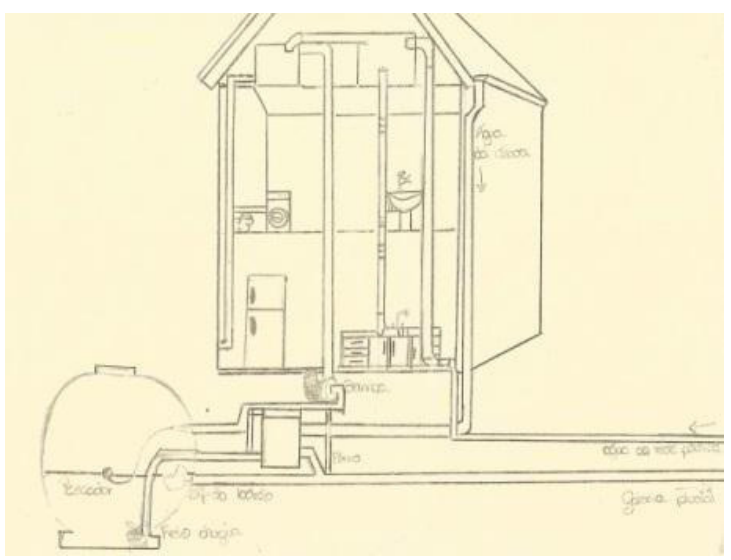

Fonte: Próprio Autor.

- Semanas 20 a 22 - Foram reproduzidos de Obras de Arte destacando as formas de representação da água: volume, cor e movimento, estimulando e provocando a curiosidade do aluno. Como exemplo podemos citar a “A Partida das Monções (1897)” de José Ferraz de Almeida Júnior, "Lua na Água, de Tarsila do Amaral (1928)" e "O Pescador (1925)". $\mathrm{Na}$ Geografia as leituras das imagens também foram exploradas de forma bidimensional e tridimensional, destacando os elementos que sofreram transformações na paisagem. Os alunos se reuniram e criaram uma obra de arte sobre o tema em questão, chamando a atenção do espectador, conforme demonstra as Figuras: 30 e 31.

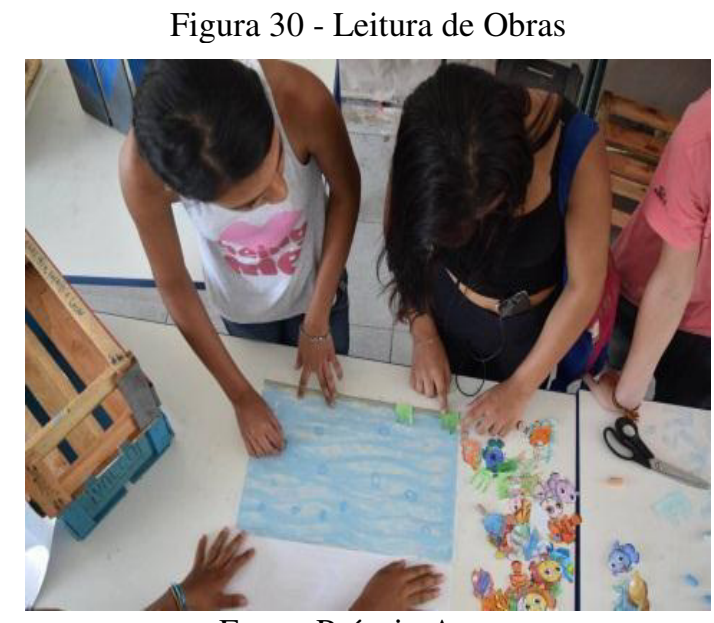

Fonte: Próprio Autor.
Figura 31 - Obra em Reprodução

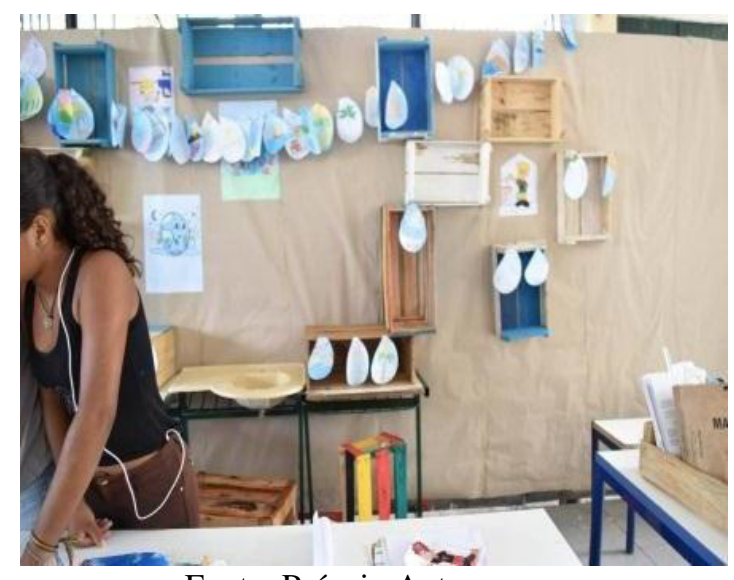

Fonte: Próprio Autor.

- Semanas 23 a 28 - A partir da semana 23 o ensino por meio do computador passou a fazer parte do processo. Nessas aulas, o docente apresentou os principais comandos e sugestões para construção de um blog. Os alunos foram ao laboratório de informática e iniciaram a construção desse blog. As Figuras 32 e 33 evidenciam essas atividades. 
Figura 32 - Laboratório de Informática

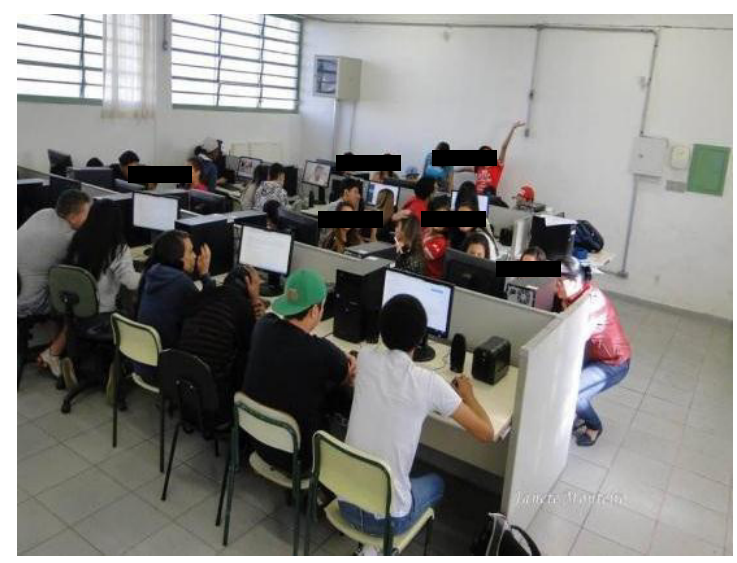

Fonte: Próprio Autor.
Figura 33 - Construção do Blog

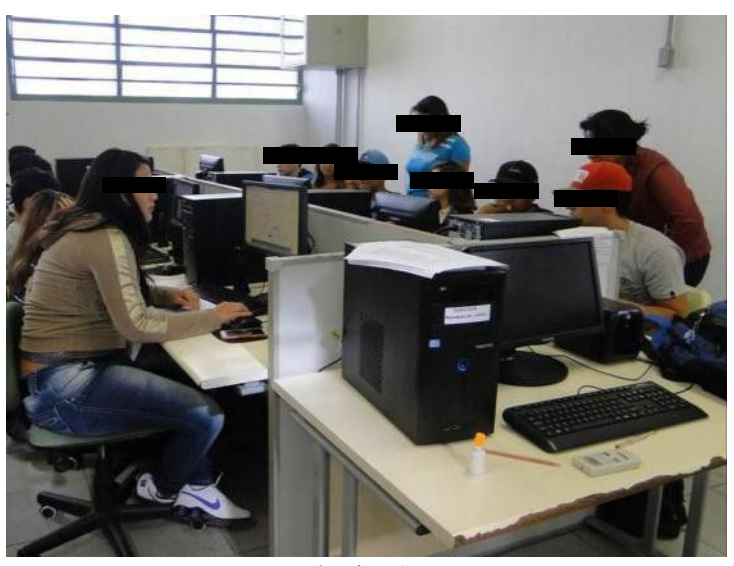

Fonte: Próprio Autor.

- Semanas 29 a 30 - Foram elaboradas modelos e Maquetes em Projetos. Nessa aula houve uma avaliação por meio de apresentação das maquetes, cada grupo tinha que demonstrar a sua maquete funcionando, onde percebeu-se um foco em sustentabilidade, com o baixo uso de recursos financeiros e utilização de materiais reciclados. Isso é evidenciado nas Figuras 34 e 35.

Figura 34 - Avaliação

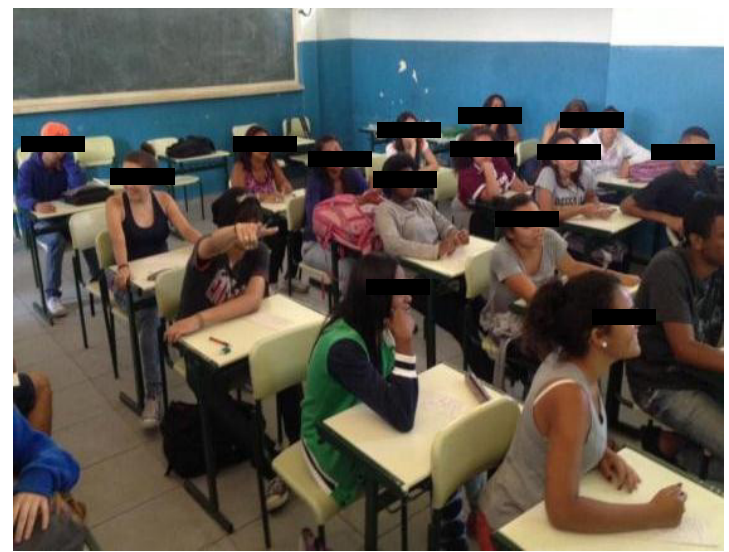

Fonte: Próprio Autor.
Figura 35 - Apresentação das Maquetes

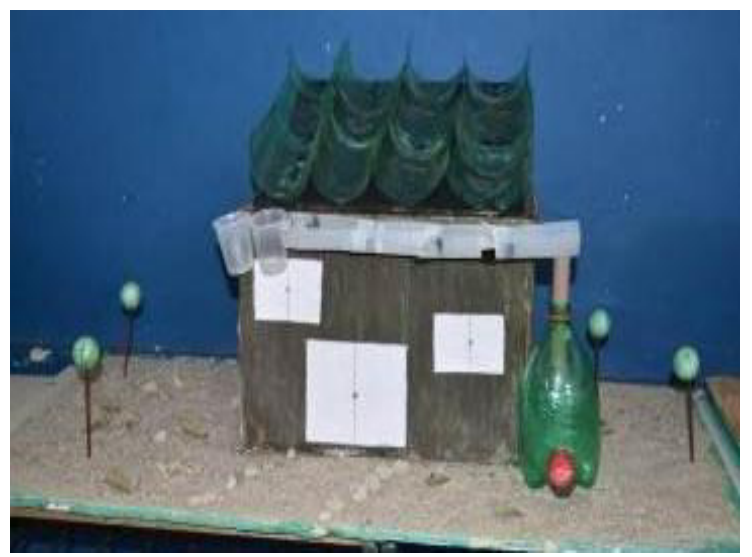

Fonte: Próprio Autor.

- Semana 31 - Foram realizadas atividades práticas para a melhoria das maquetes e encerramento do projeto. Os alunos ajustaram detalhes de suas maquetes em sala de aula com o auxílio do docente e monitor da disciplina. As Figuras 36 e 37 evidenciam essas atividades. 
Figura 36 - Apresentação da Maquete

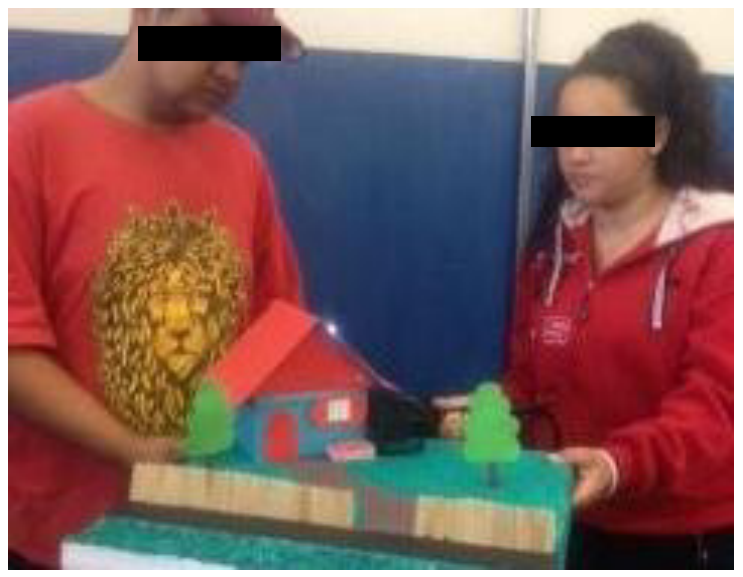

Fonte: Próprio Autor.
Figura 37 - Maquete Ajustada

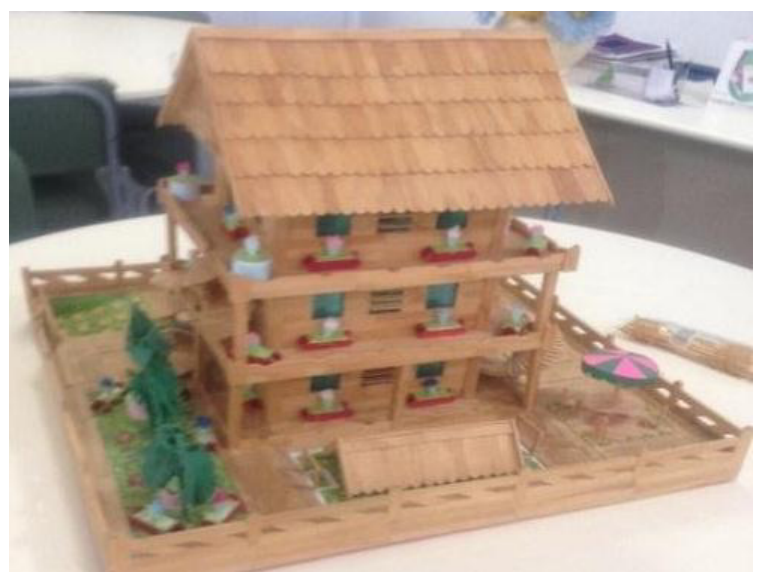

Fonte: Próprio Autor.

- Semana 32 a 35 - Foi realizada a apresentação do Relatório Final dos Projetos e explicação dos grupos sobre como funciona a geração de energia elétrica de uma casa, por meio de um protótipo. As Figuras 38 e 39 evidenciam essa prática.

Figura 38 - Protótipo em Construção

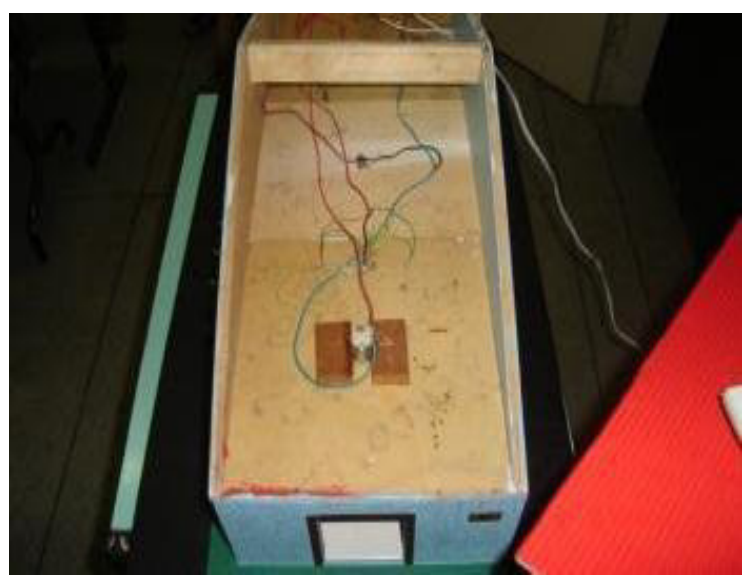

Fonte: Próprio Autor.
Figura 39 - Ajuste do Protótipo

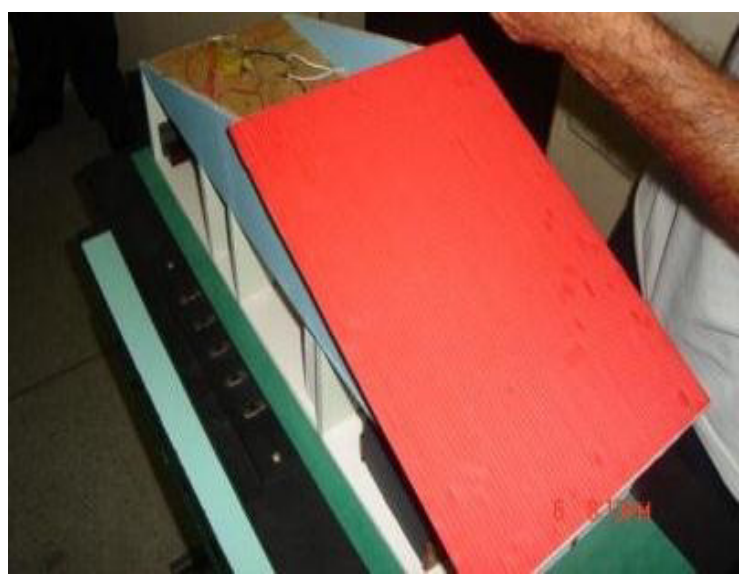

Fonte: Próprio Autor.

- Semana 36 - Foi realizada apresentação das Maquetes na Feira de Ciências. No evento anual "Semana de Ciências", a instituição abre as portas para a comunidade para a apresentação de projetos e atividades realizadas pelos alunos em diversas disciplinas durante o ano. Uma sala de aula foi reservada exclusivamente para o projeto de Educação Ambiental. Professores de outras disciplinas e de outra unidade escolar foram orientados a avaliar a qualidade dos projetos. O evento durou dois dias consecutivos. As Figuras 40 e 41 demonstram essas atividades. 
Figura 40 - Exposição das Maquetes

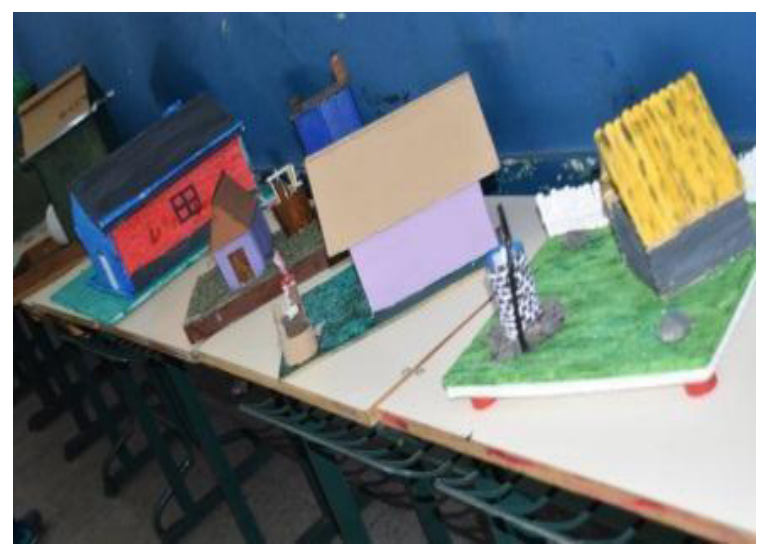

Fonte: Próprio Autor.
Figura 41 - Visitação na Feira de Ciências

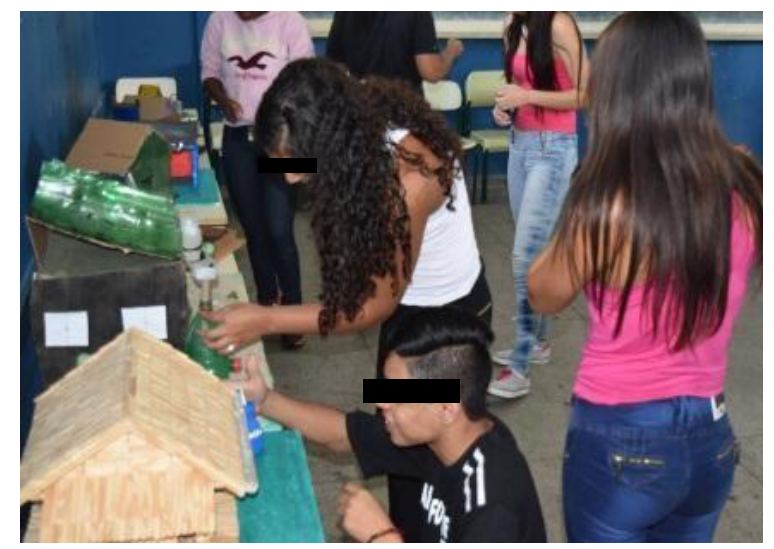

Fonte: Próprio Autor.

- Semana 37 - Foram realizadas orientações quanto os projetos. Esse encontro foi realizado na sala de leitura, após a "Feira de Ciências" para uma verificação e discussão sobre a teoria e a prática, levando em consideração comentários feitos nas avaliações dos professores e a análise de falhas realizada nas semanas 32 e 33. Logo em seguida, foi aplicada uma avaliação dissertativa, onde o aluno também pôde contribuir com sua opinião sobre o desenvolvimento do projeto. Esse fato é demonstrado nas Figuras 42 e 43.

Figura 42 - Análise da Feira

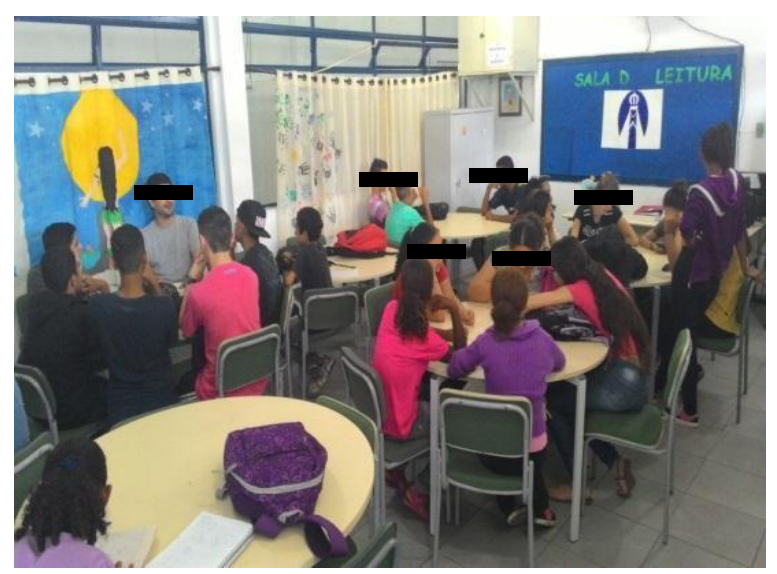

Fonte: Próprio Autor.
Figura 43 - Avaliação Escrita

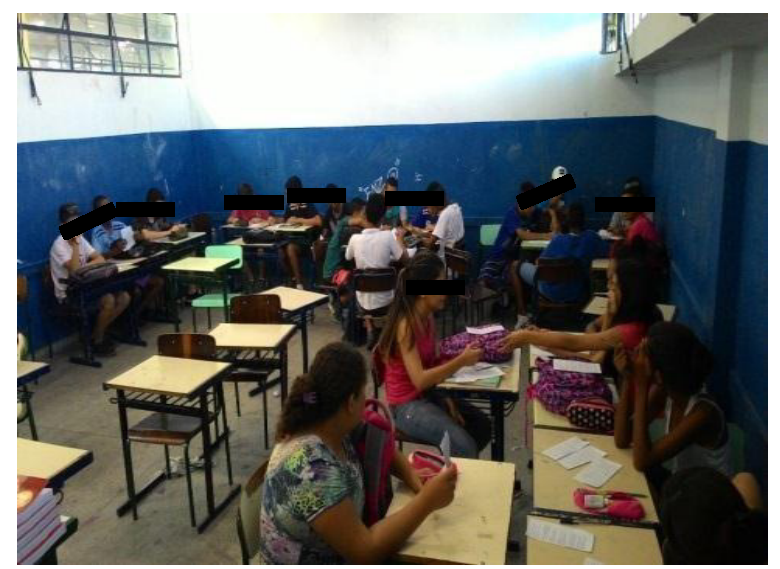

Fonte: Próprio Autor.

- Semanas 38 e 39 - Avaliação Final. As questões de avaliação final foram aplicadas individualmente aos 42 alunos presentes na sala de aula, conforme é demonstra nas Figuras 44 e 45. 
Figura 44 - Avaliação em Sala de Aula

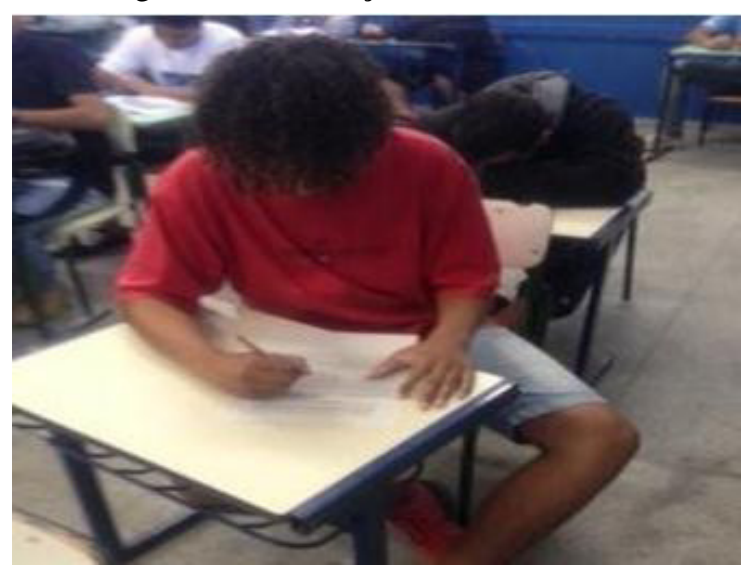

Fonte: Próprio Autor.
Figura 45 - Avaliação Individual

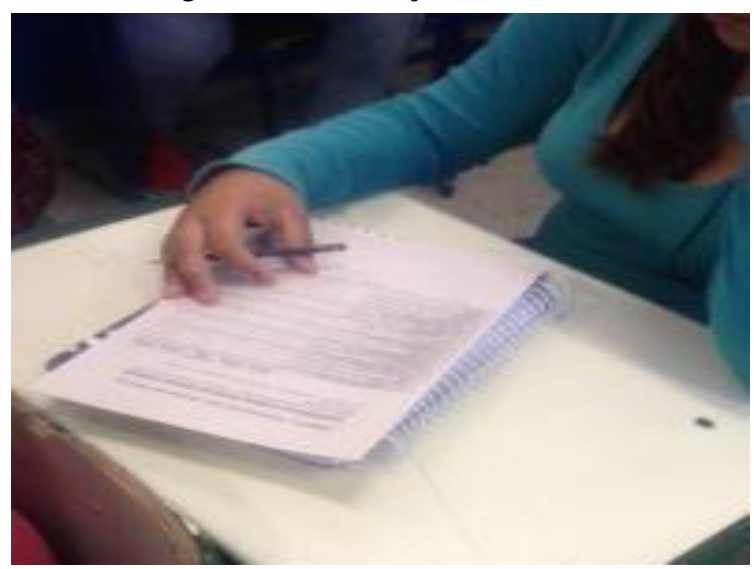

Fonte: Próprio Autor.

- Semana 40 - Foi o dia do encerramento do Projeto. São feitos relatos e discussões sobre o aprendizado durante o ano e dado um questionário de avaliação das disciplinas e do método. Os alunos também apresentam o blog desenvolvido. Nesse dia, um aluno do Ensino Médio foi convidado para falar da implantação de uma cisterna real no ambiente escolar a partir dos projetos desenvolvidos em sala de aula, conforme Figuras 46 a 49.

Figura 46 - Espaço de Construção

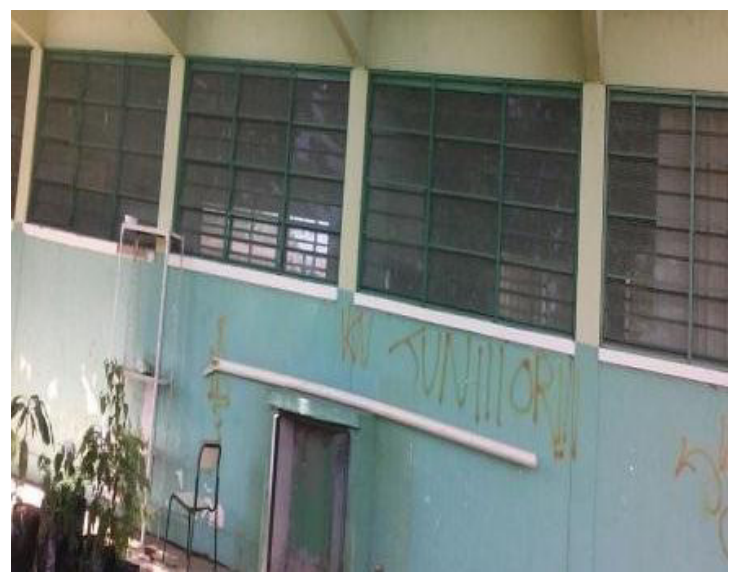

Fonte: Próprio Autor.
Figura 47 - Cisterna Real

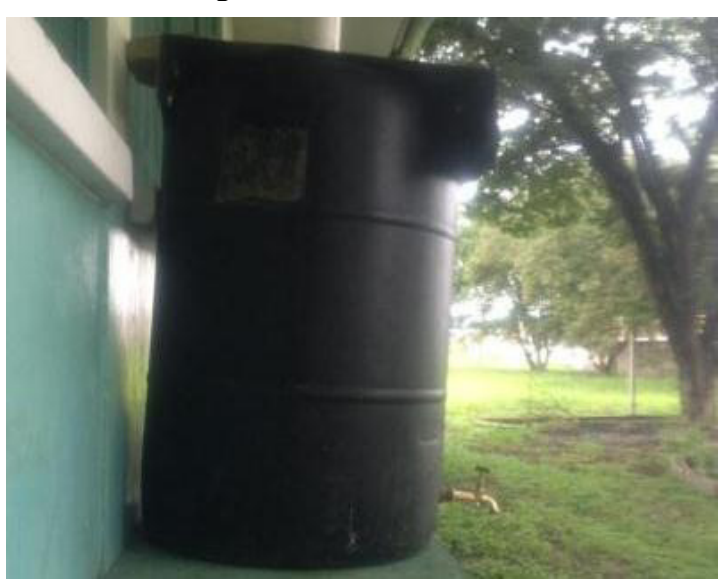

Fonte: Próprio Autor. 
Figura 48 - Cisterna Instalada

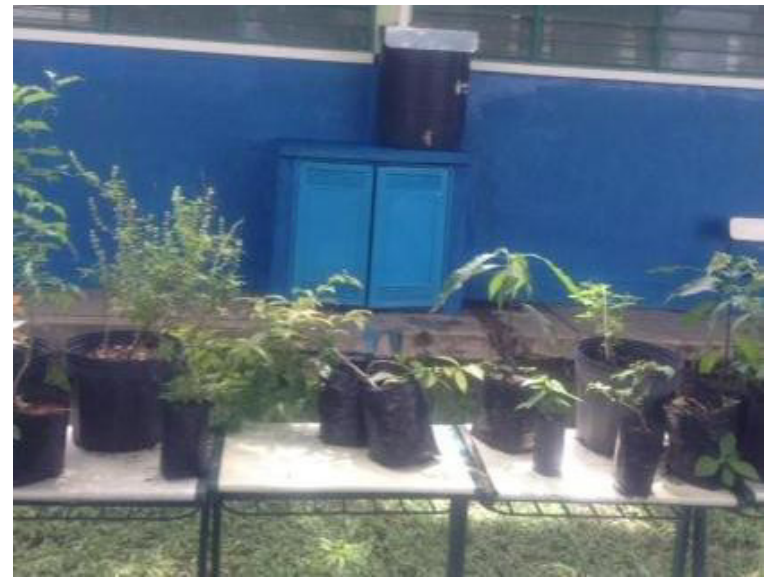

Fonte: Próprio Autor.
Figura 49 - Uso da Cisterna

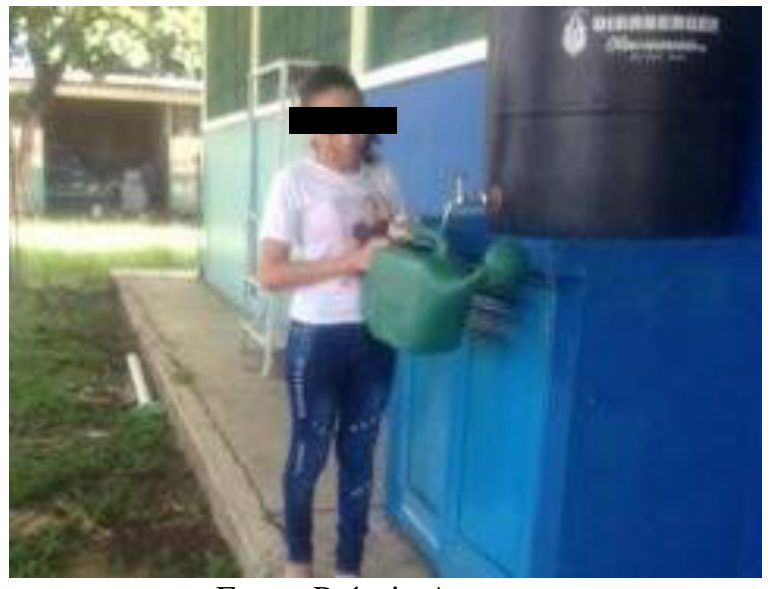

Fonte: Próprio Autor.

Durante todo o período, pontos de checagem (check points) foram estabelecidos para o controle formal do andamento do projeto, similarmente ao que ocorre na vida profissional, na qual metas e prazos fazem parte da rotina. Esses pontos de controle estabelecem o ritmo de andamento do projeto, mantendo alguma liberdade de ação para as equipes. O objetivo foi o de controlar aspectos básicos da execução do projeto, para que o ritmo do trabalho a ser realizado pudesse fluir adequadamente. $\mathrm{Na}$ sala de leitura foi disponibilizado material de para serem utilizados durante todo o período.

\subsection{Avaliação dos Alunos}

O desempenho de cada participante do projeto foi verificado pelo trabalho em equipe, como um todo, sendo que foram avaliadas a competência da leitura e escrita, a capacidade de solucionar problemas e dirimir conflitos e de desenvolver competências técnicas de forma efetiva e responsável em cada disciplina envolvida no projeto. As competências que os alunos devem adquirir por meio da realização do projeto são, em grande parte, as competências específicas que também devem desenvolver nas disciplinas de apoio direto ao projeto Educação Ambiental, a saber: Língua Portuguesa, Matemática, História, Geografia, Arte e Física. Além dessas competências, foram desenvolvidas outras, tais como: Interpretar o significado da legenda para a representação dos fenômenos geográficos, identificar e comparar os elementos que constituem o clima e os fatores que nele interferem, identificar, comparar e descrever os diferentes recursos utilizados pela sociedade no uso exagerado das fontes de energia e suas consequências. 


\subsection{Avaliação pelos Alunos}

No estudo de análise quantitativa para avaliação da percepção dos alunos, os resultados foram consolidados a partir das respostas obtidas com um questionário. Com uma população composta por 58 alunos, vinte e oito alunos do ensino fundamental e trinta do ensino médio, as variáveis da pesquisa foram à aplicação do método de Aprendizagem Baseada em Projetos e a percepção dos alunos quanto à dinâmica do método. A identificação dos mesmos foi opcional, assim como suas críticas e sugestões. As questões foram abertas. Nas Figuras 50 a 62 são representadas as respostas dadas por dois alunos participantes da pesquisa, usada como amostra neste trabalho.

A Questão 1 (Figuras 50 e 51) questiona a aplicação do método com o ensino de Física. Observa-se que as respostas de dois alunos indicam que a disciplina do currículo contribuiu para a melhoria da qualidade do ensino, ou seja, as aulas começaram a fazer sentido, no conteúdo que foi ensinado e o que foi assimilado pelo aluno.

Figura 50 - Resposta dada pelo aluno a participante da pesquisa quanto ao aprendizado de Física.

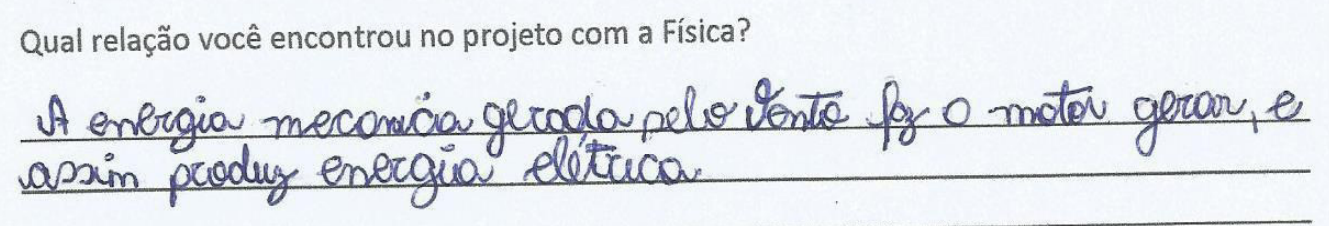

Fonte: Dados da Pesquisa do Autor (2017).

Figura 51 - Resposta dada por um aluno participante da pesquisa quanto ao aprendizado de Física.

Qual relação você encontrou no projeto com a Física?

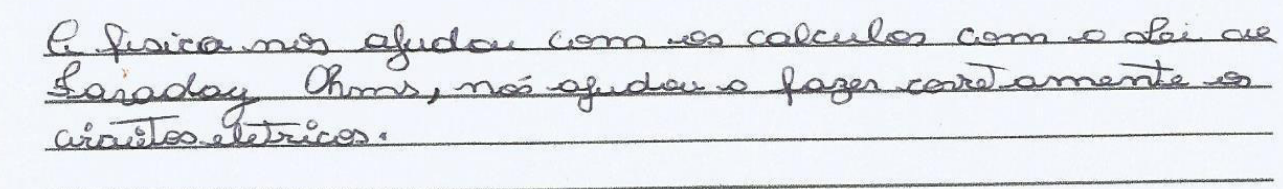

Fonte: Dados da Pesquisa do Autor (2017)

A Questão 2 (Figuras 52 e 53) questiona a aplicação do método com o ensino de Geografia. Percebe-se pelas respostas de dois alunos que a disciplina abordou temas relevantes em relação ao projeto. Os mesmos alunos fizeram justificativas dos conceitos apreendidos. 
Figura 52 - Resposta dada por um aluno participante da pesquisa quanto ao aprendizado de Geografia Qual relação você encontrou no projeto com a Geografia?

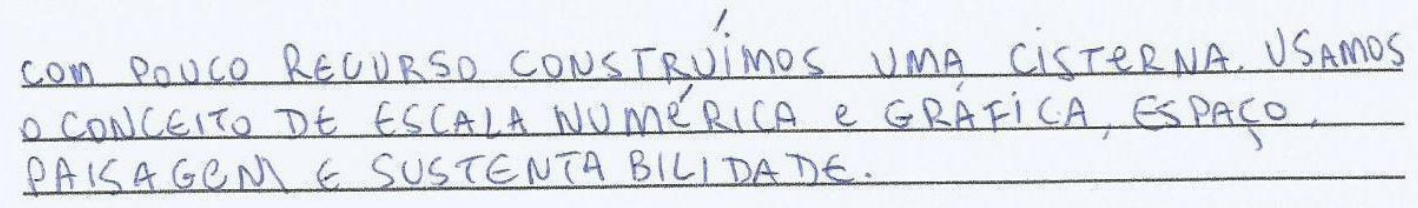

Fonte: Dados da Pesquisa do Autor (2017).

Figura 53 - Resposta dada por um aluno participante da pesquisa quanto ao aprendizado de Geografia.

Qual relação você encontrou no projeto com a Geografia?

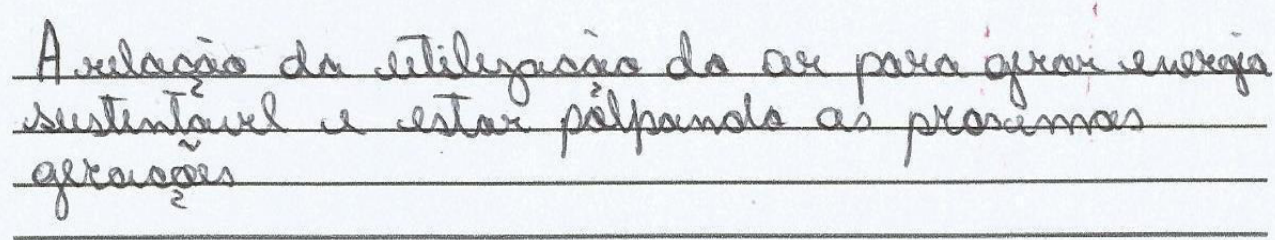

Fonte: Dados da Pesquisa do Autor (2017).

A Questão 3 (Figuras 54 e 55) questiona a aplicação do método com o ensino de Matemática. As respostas de dois alunos mostram que as aulas de matemática ficaram mais prazerosas e que eles se sentiram desafiados nas atividades desenvolvidas.

Figura 54 - Resposta dada por um aluno participante da pesquisa quanto ao aprendizado de Matemática.

Qual relação você encontrou no projeto com a matemática?

A relacaio que encontrer da senergia com a matemática foi que aprendemos a fager escala os gráficos de Setor, gnáfio de linhas, bouras, e que con isso, conseguimos formas as respectervas estalisticas

Fonte: Dados da Pesquisa do Autor (2017) 
Figura 55 - Resposta dada por um aluno participante da pesquisa quanto ao aprendizado de Matemática.

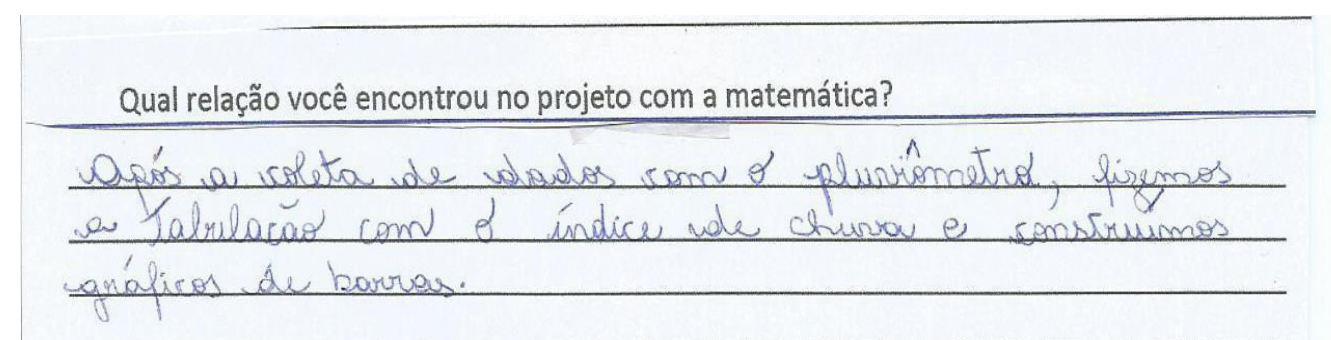

Fonte: Dados da Pesquisa do Autor (2017).

A Questão 4 (Figuras 56 e 57) questiona a aplicação do método com o ensino de Arte. Observa-se pelas respostas de dois alunos que a disciplina conseguiu desenvolver uma aprendizagem significativa, despertando o interesse dos alunos, dentro de um contexto que eles já conheciam.

Figura 56 - Resposta dada por um aluno participante da pesquisa quanto ao aprendizado de Arte.

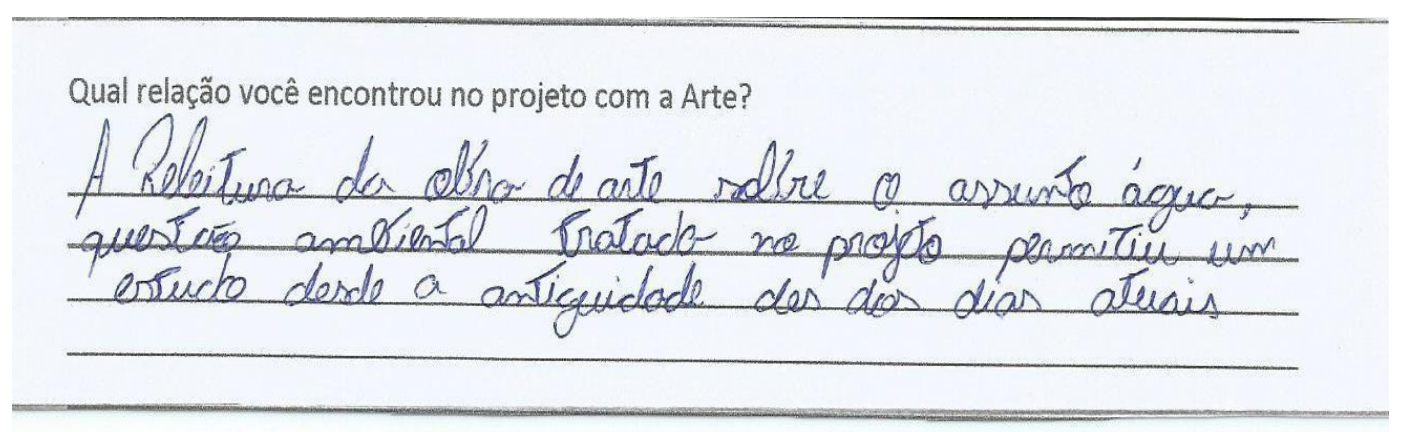

Fonte: Dados da Pesquisa do Autor (2017).

Figura 57 - Resposta dada por um aluno participante da pesquisa quanto ao aprendizado de Arte.

Qual relação você encontrou no projeto com a Arte?

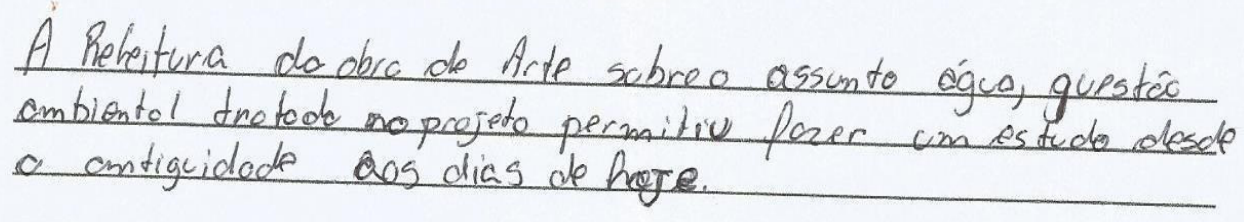

Fonte: Dados da Pesquisa do Autor (2017). 
A Questão 5 (Figuras 58 e 59) questiona a opinião dos alunos em relação a metodologia ativa - ABP aplicado a Educação Ambiental. A resposta de dois alunos aponta pela preferência do método utilizado e afirmam que se sentiram contagiados com o projeto.

Figura 58 - Resposta dada por aluno participante da pesquisa quanto à aprendizagem em relação à ABP.

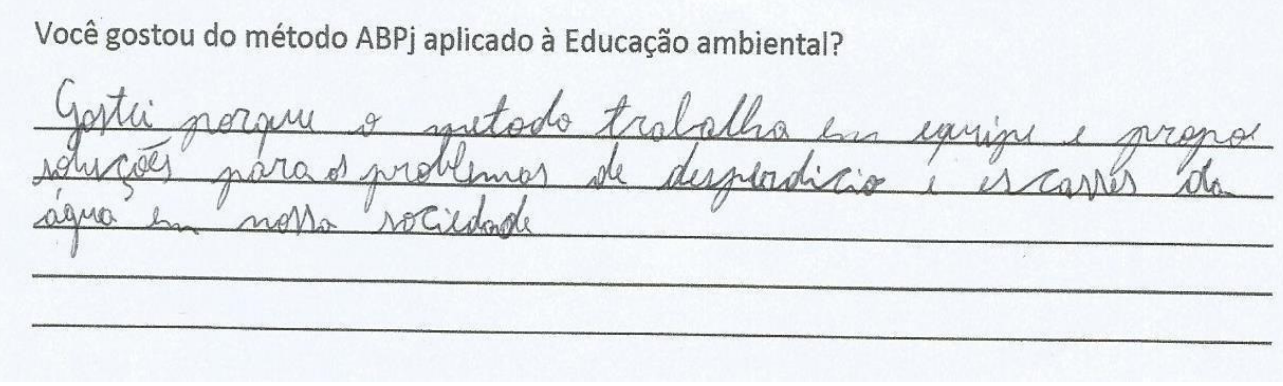

Fonte: Dados da Pesquisa do Autor (2017).

Figura 59 - Resposta dada por um aluno participante da pesquisa quanto à aprendizagem em relação à ABP.

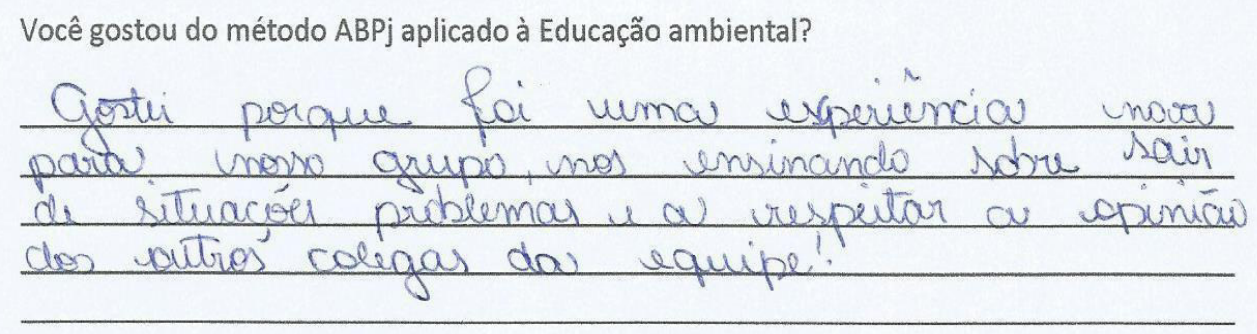

Fonte: Dados da Pesquisa (2017).

A Questão 6 relaciona a participação do aluno no Projeto. Um exemplo são os alunos X, Y e Z, (Figuras 60, 61 e 62) que responderam que se sentiram mais motivados e mais responsáveis, sendo o projeto uma experiência nova para sua aprendizagem.

Figura 60 - Resposta dada pelo aluno X participante da pesquisa em relação a sua participação no Projeto.

Quais melhorias sugerem para o andamento do projeto?

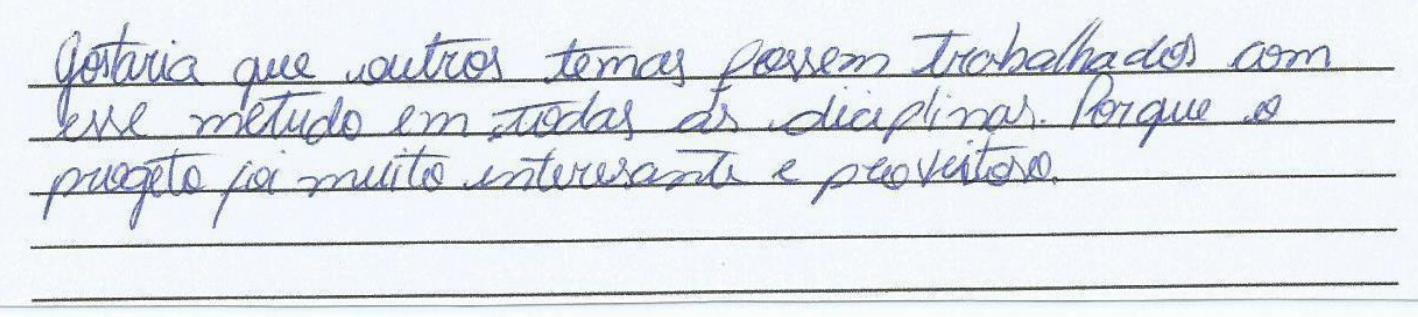

Fonte: Dados da Pesquisa do Autor (2017). 
Figura 61 - Resposta dada pelo aluno Y participante da pesquisa em relação a sua participação no Projeto.

Deixe sua crítica ou sugestão em relação ao método de Aprendizagem por Projetos.

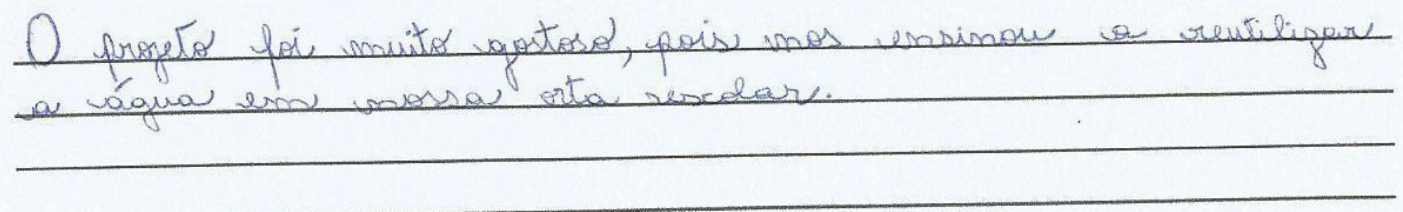

Fonte: Dados da Pesquisado Autor (2017).

Figura 62 - Resposta dada pelo aluno Z, participante da pesquisa em relação a sua participação no Projeto.

Deixe sua crítica ou sugestão em relação ao método de Aprendizagem por Projetos.

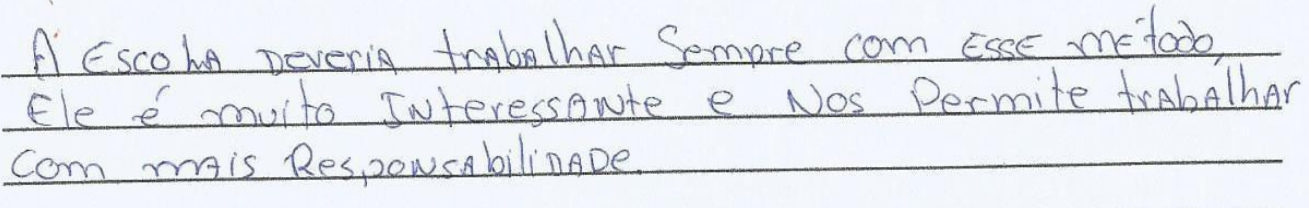

Fonte: Dados da Pesquisado Autor (2017).

A partir desse pressuposto percebe-se nessas respostas que os alunos se interessaram pelo método $\mathrm{ABP}$, pois proporciona uma perspectiva de ensino mais dinâmico e atraente, e o educando acaba aprendendo a dividir funções, encontrando o lado bom de cada disciplina, desenvolvendo suas potencialidades cognitivas, sociais e afetivas, atingindo assim o real objetivo do ensino de ciências, que é formar um indivíduo que busque o conhecimento com responsabilidade e competência para enfrentar desafios.

\subsection{Análise e discussão dos Dados da Pesquisa}

Um segundo questionário baseado em um modelo, criado por PEREIRA foi aplicado nos alunos que participaram da pesquisa, a aplicação ocorreu em sala de aula individualmente, cujo objetivo era avaliar a aplicação da ABP e das Competências Transversais por meio da Educação Ambiental. A distribuição das questões foi definida como: múltipla escolha (no qual escolhe apenas uma opção). Os resultados apresentados referem-se às análises semiquantitativas do questionário aplicado com os alunos que participaram de todo o processo. A partir dos questionários (Apêndice A), obteve-se as informações que foram analisadas e discutidas. 
As Questões 1, 2 e 3 (Figura 63 a 66) referiram-se à competência de trabalhar em equipe. O objetivo é o de perceber a contribuição e o esforço do aluno ao buscar informações complementares ao projeto e a atenção dada às partes teóricas ministradas em sala pelo docente.

Figura 63 - Trabalho em Equipe

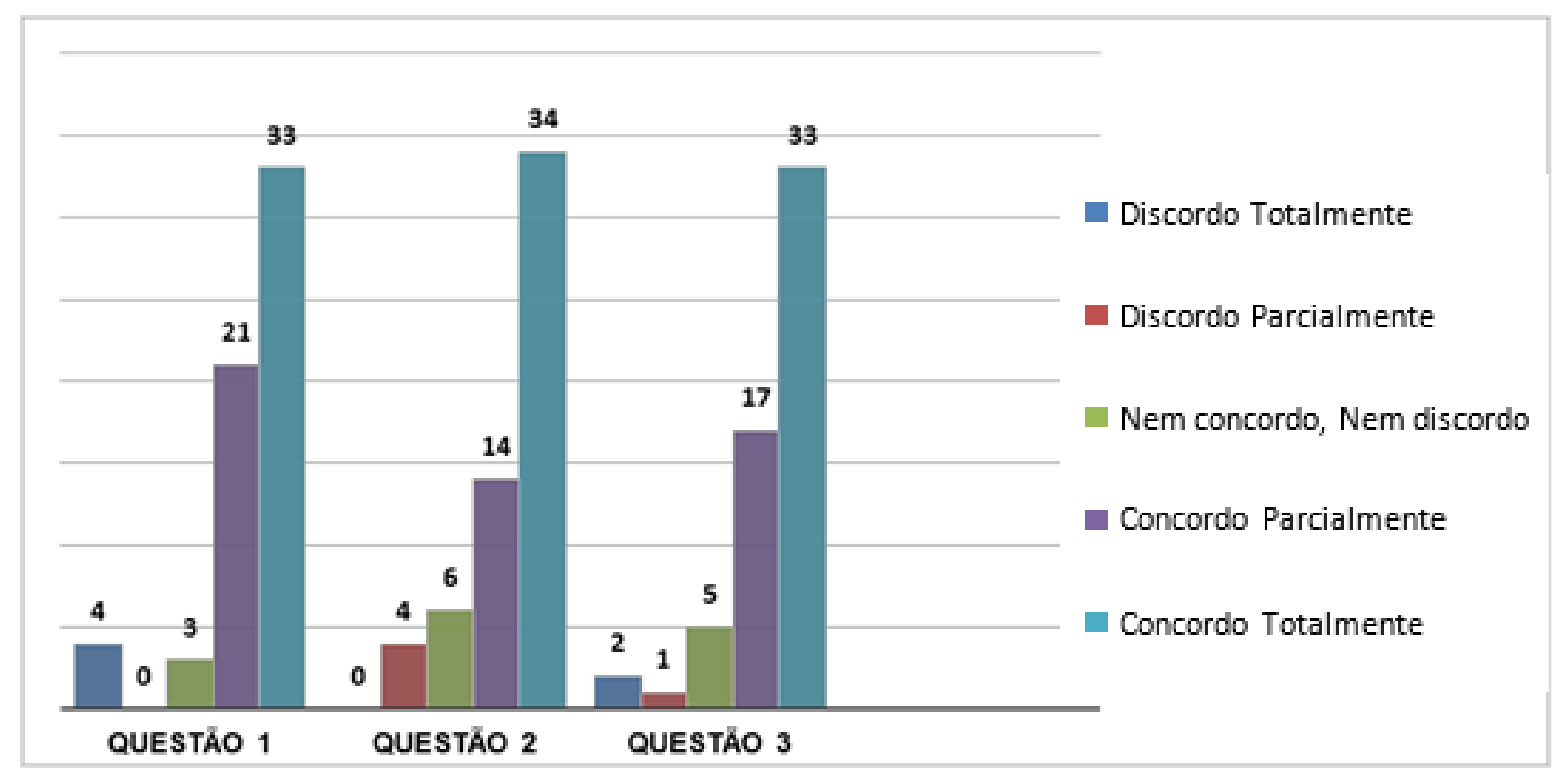

Fonte: Próprio Autor.

Na primeira questão: Os membros do grupo têm contribuído para o sucesso do trabalho? Com base nas respostas dos alunos, 54\% dos entrevistados, concordaram totalmente que os membros dos grupos contribuíram de forma significativa para o desenvolvimento de todas as etapas do trabalho e $34 \%$ concordaram parcialmente.

Figura 64 - Questão1

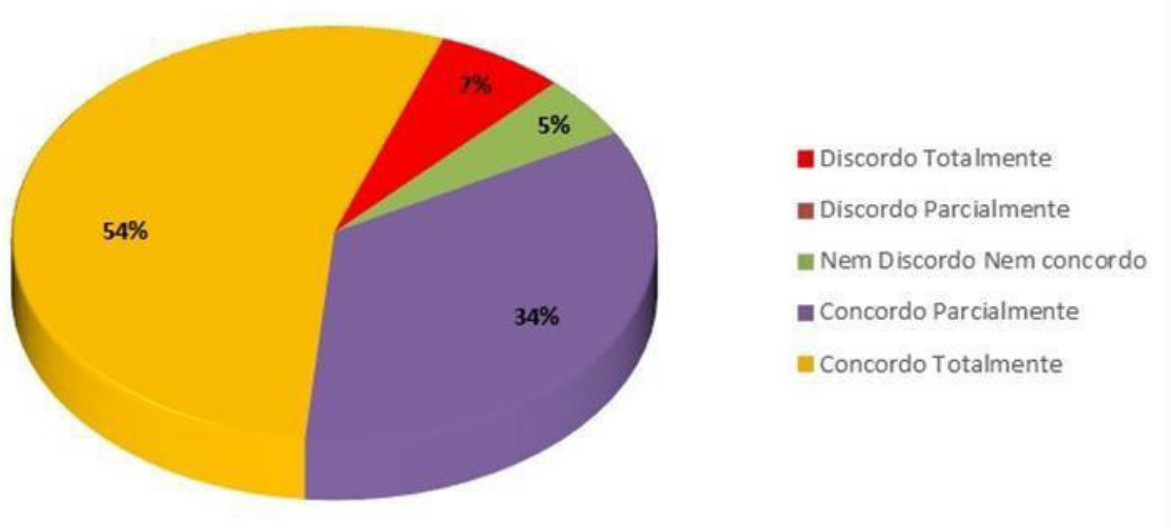

Fonte: Próprio Autor. 
Na segunda questão: Os membros dos grupos têm participado de todas as reuniões? $59 \%$ dos entrevistados afirmam que sim, e $7 \%$ discordaram parcialmente.

Figura 65 - Questão 2

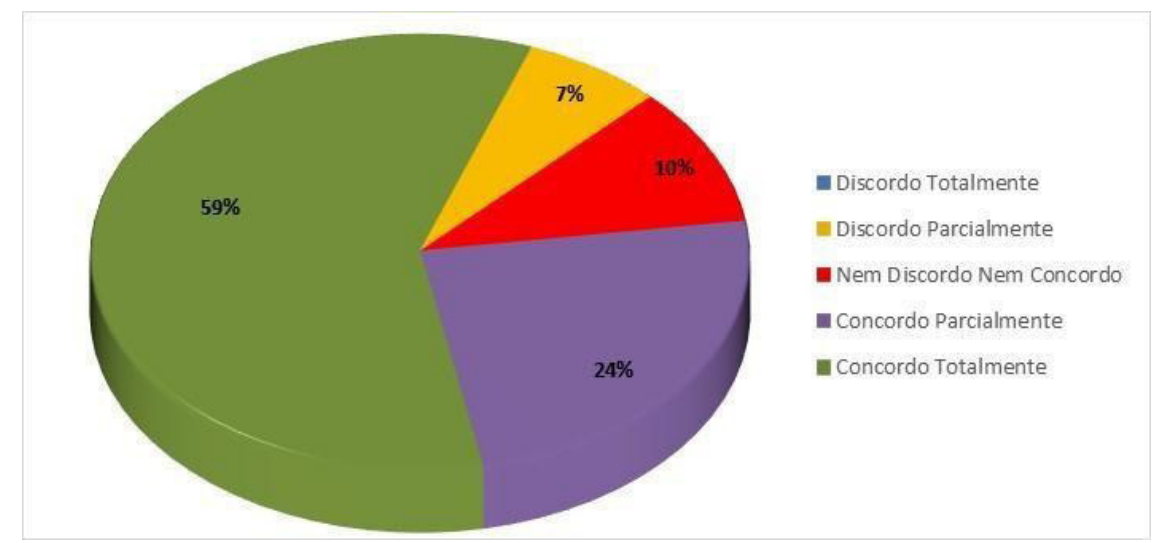

Fonte: Próprio Autor.

Na terceira questão: Os conflitos vivenciados pelo grupo têm sido superados de maneira coerente e respeitosa? Pode-se notar que 3\% discordaram que os conflitos foram superados. Mas 57\% afirmaram que os grupos são locais ideais para interagir, ouvindo opiniões e construindo conceitos.

Figura 66 - Questão 3

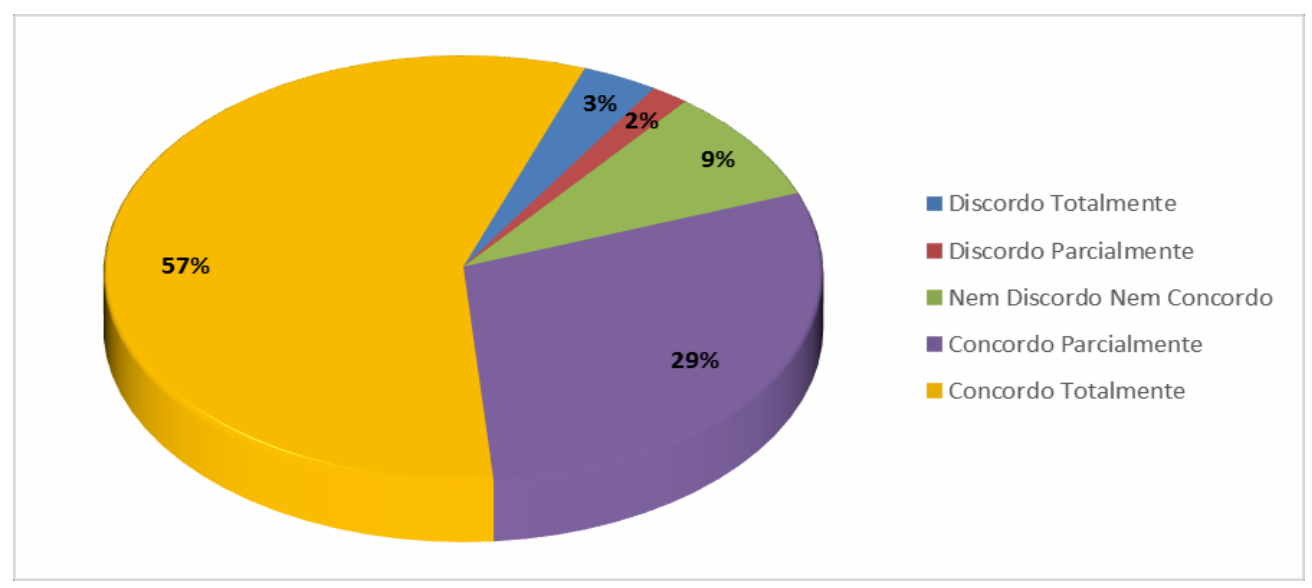

Fonte: Próprio Autor.

As questões 4 e 5 referem-se ao desenvolvimento de competência pessoal, (Figuras: 67 a 69). 
Figura 67 - Competência Pessoal

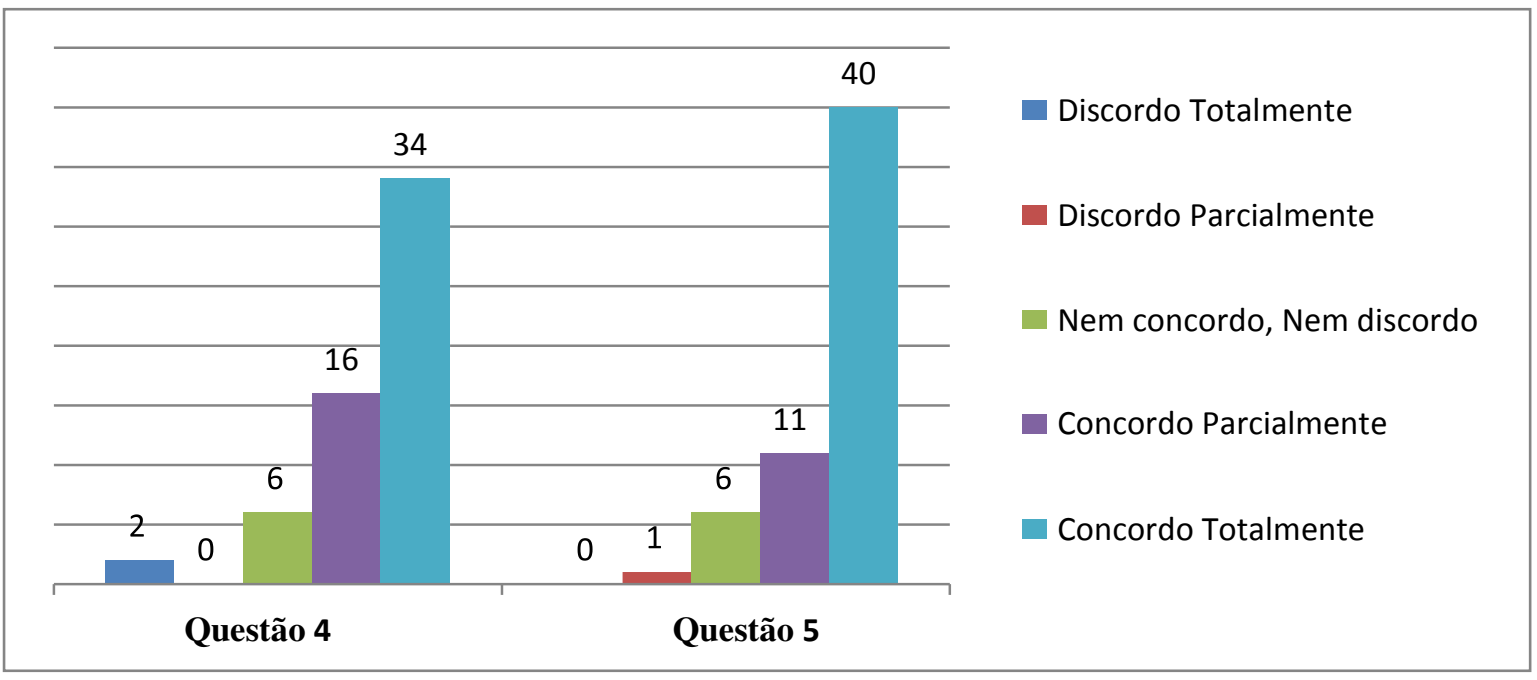

Fonte: Próprio Autor.

Na quarta questão: O projeto ajuda a desenvolver a criatividade para a resolução de problemas? Percebe-se que 59\% dos componentes dos grupos concordam totalmente que o projeto ajuda desenvolver habilidades e competências com mais criatividade. Nessa perspectiva é relevante a reflexão sobre os diferentes tipos de problemas que podem ser propostos aos alunos, destacando suas características e funções no ensino e na aprendizagem.

Figura 68 - Questão 4

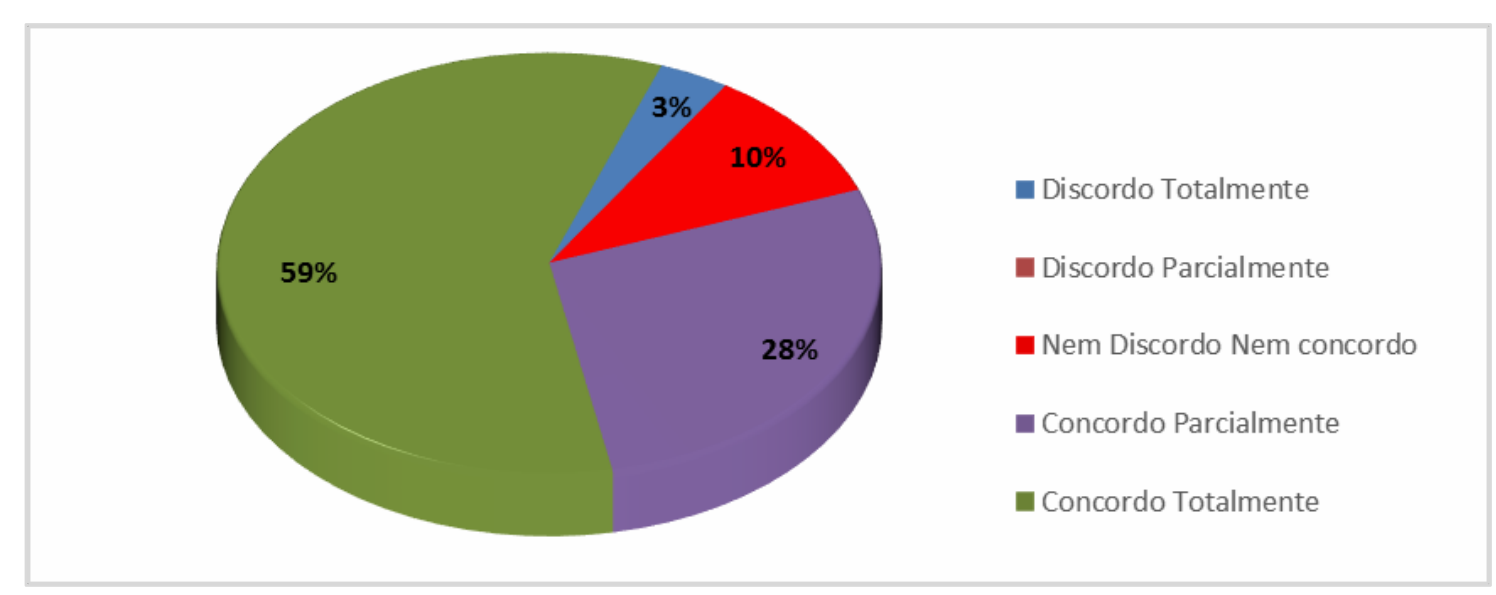

Fonte: Próprio Autor.

$\mathrm{Na}$ quinta questão: O projeto possibilitou o desenvolvimento do senso crítico, presentes nas diferentes propostas de trabalho? Observa-se que 59\% dos alunos, concordaram totalmente. Pois ao realizar análise e questionamentos, o aluno percebeu que houve aprimoramento de suas capacidades intelectuais, encontrando maior facilidade em 
fazer perguntas e buscando respostas.

Figura 69 - Questão 5

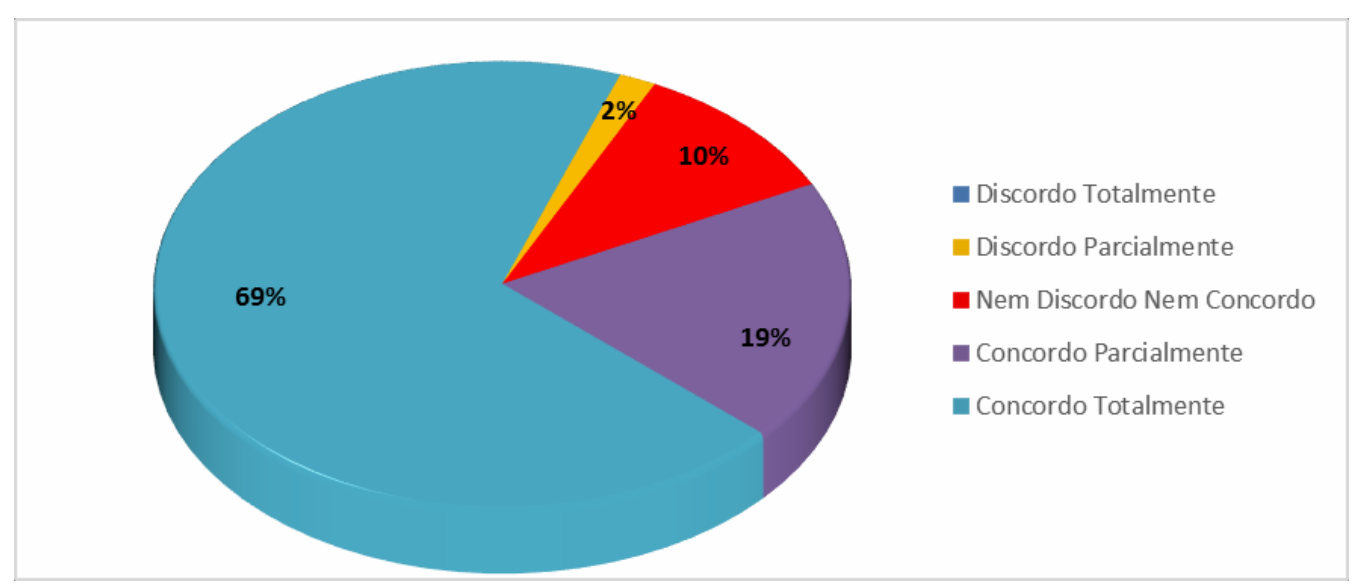

Fonte: Próprio Autor.

As questões 6 e 7 refere-se a competência de comunicação. (Figuras: 70 e 72).

Figura 70 - Competência da Comunicação

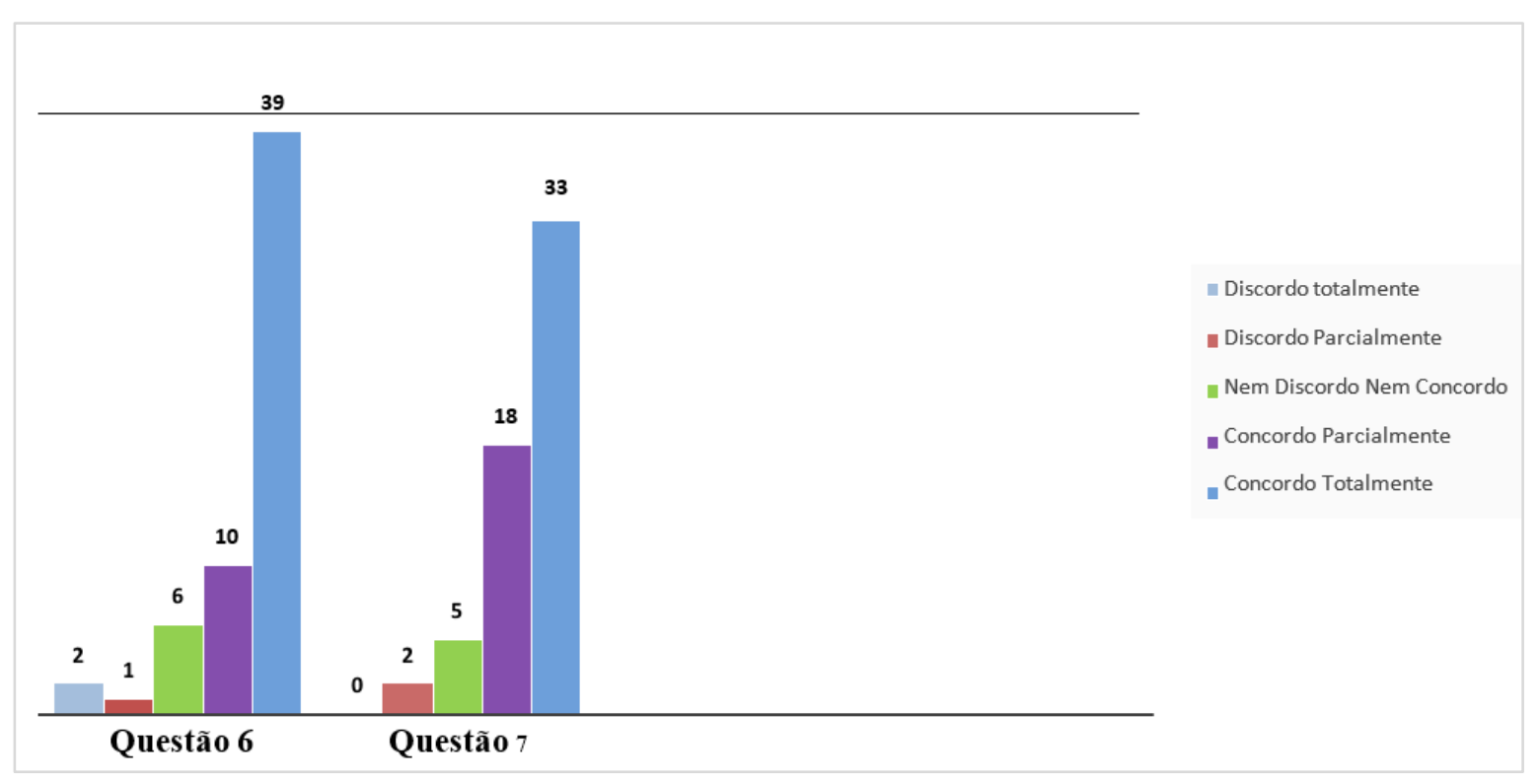

Fonte: Próprio Autor.

Na sexta questão: A comunicação do grupo, através do protocolo de comunicação tem sido eficaz? Percebe-se que 67\% afirmou estar de acordo plenamente e apenas uma minoria de $4 \%$ discorda. 
Figura 71 - Questão 6

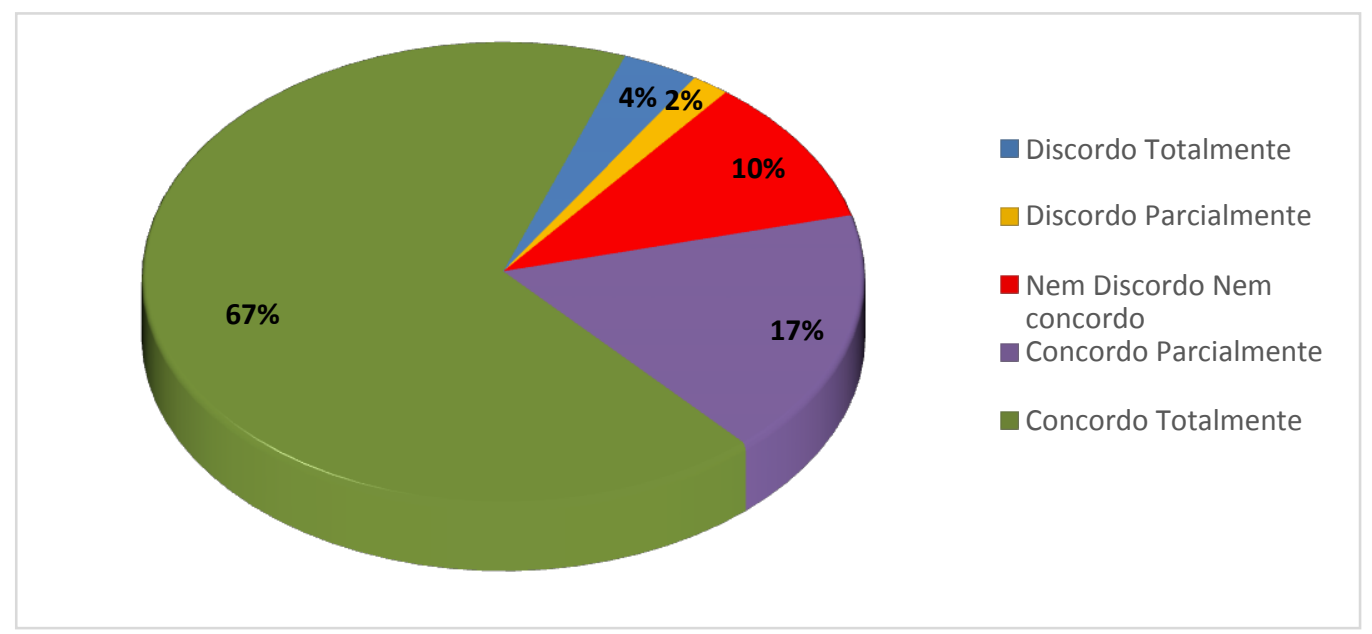

Fonte: Próprio Autor.

Na sétima questão: A capacidade de comunicação escrita e oral tem sido desafiada nesse projeto? A pesquisa apontou que 57\% dos alunos responderam que sim, e $31 \%$ concordaram parcialmente. Os alunos afirmaram que a leitura melhora o vocabulário e a capacidade de sintetizar as informações ajudando a escrever melhor, identificando as situações e sabendo qual o tipo de atitude se deve tomar.

Figura 72 - Questão 7

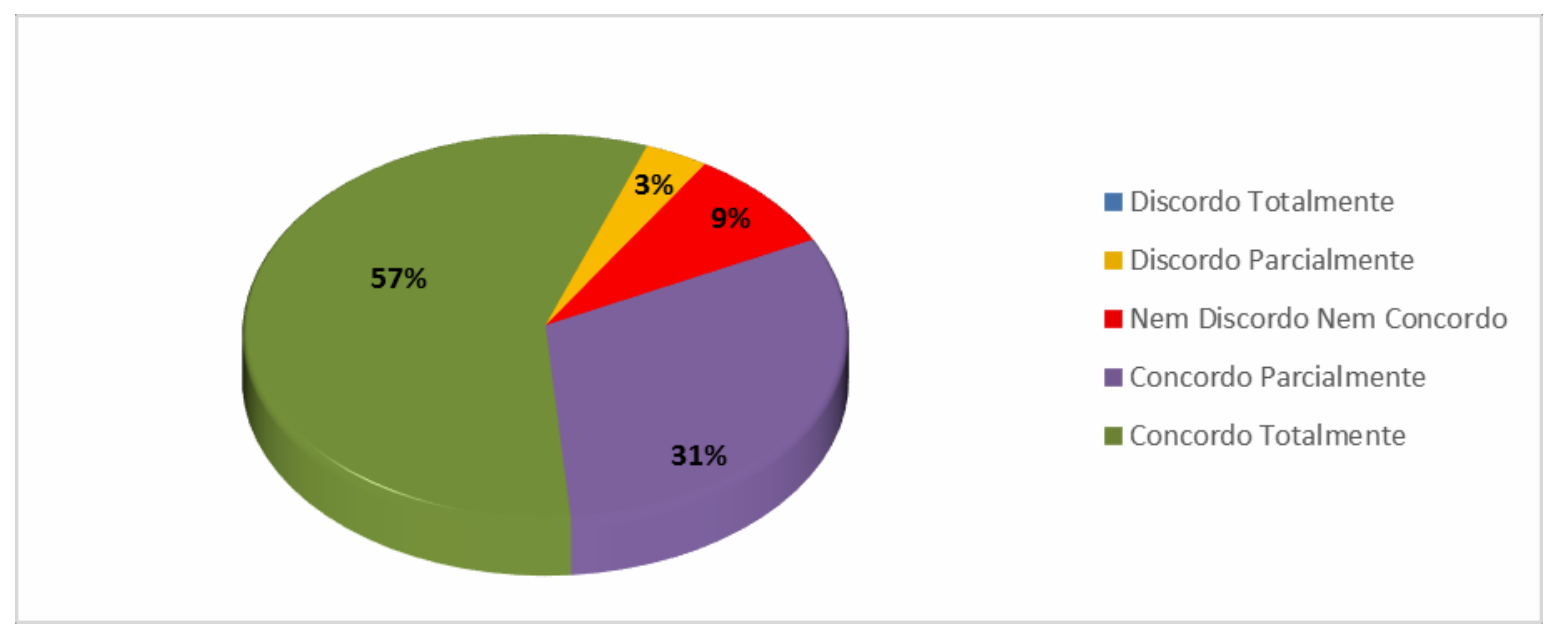

Fonte: Próprio Autor.

As questões 8 e 9 referem-se à competência de Gestão de Projeto. (Figuras 73 a $75)$. 
Figura 73- Questão 8 e 9

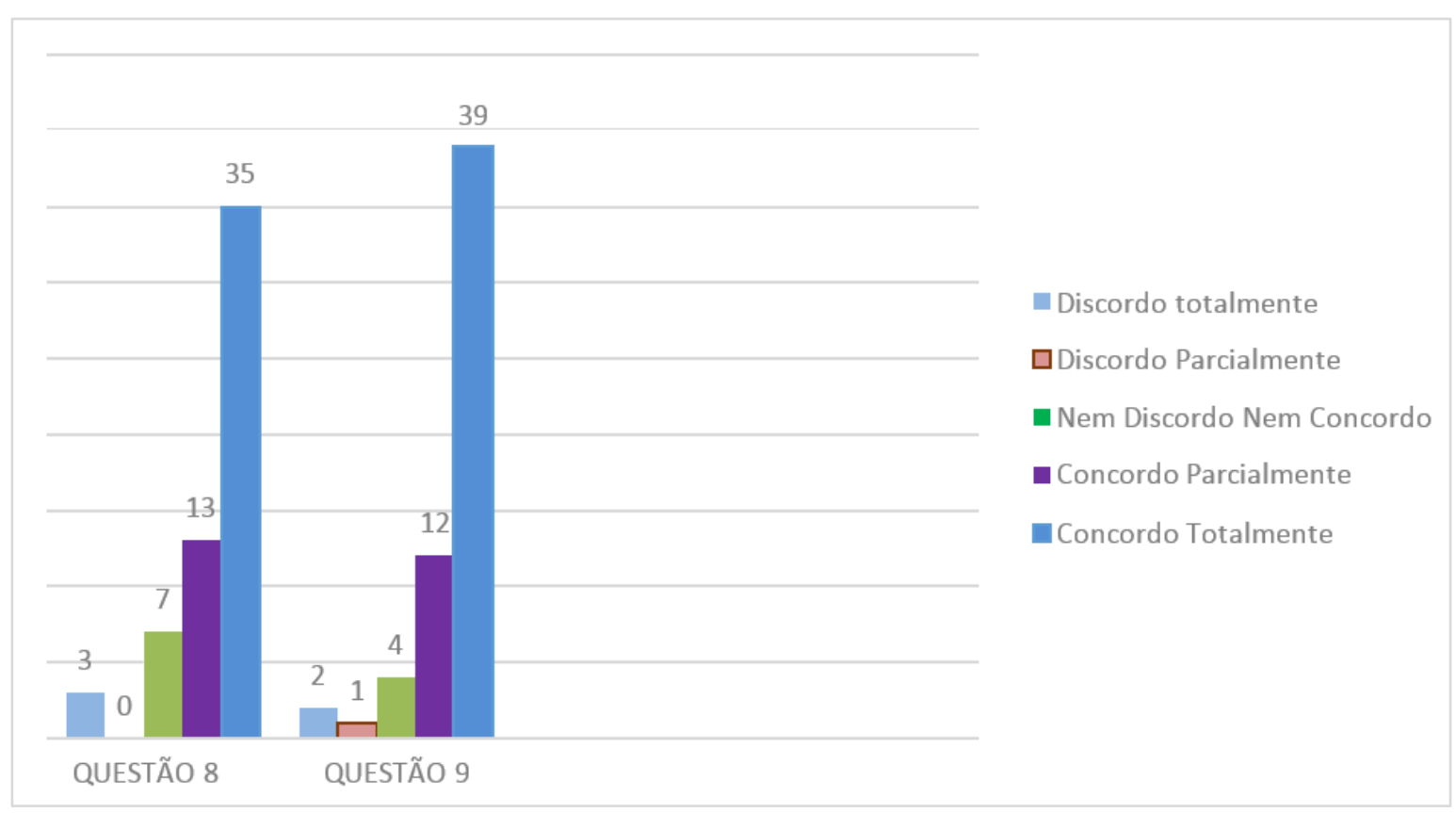

Fonte: Próprio Autor.

Na oitava questão: As reuniões foram produtivas e decisivas para a continuidade do projeto? Observa-se que $60 \%$ dos entrevistados afirmam ser importante se reunir em grupo, para que todos possam adquirir conhecimentos e organizar as atividades para cumprir os prazos estabelecidos. A pesquisa demonstra que o método é relevante e nas trocas de experiências os alunos vão aprimorando os seus conhecimentos e interagindo um com o outro.

Figura 74 - Questão 8

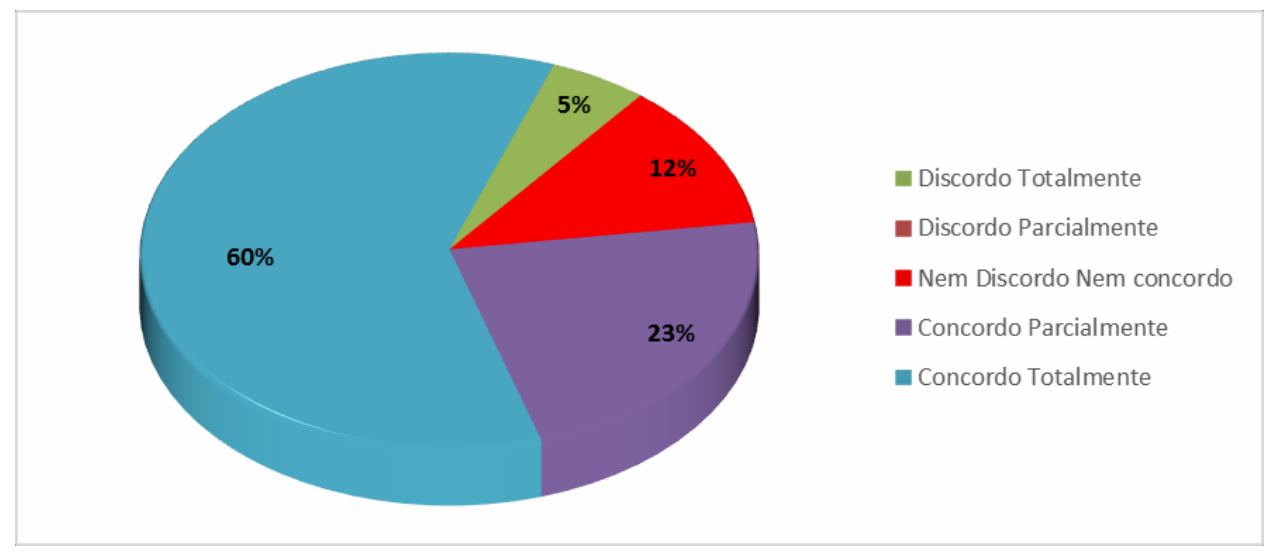

Fonte: Próprio Autor.

Na nona questão: O grupo tem cumprido todos os prazos estabelecidos? Podemos observar que $67 \%$ afirmam que sim, pois realizaram as atividades dentro dos prazos. 
Houve a discordância de apenas $3 \%$ que entregaram as atividades depois do prazo estabelecido.

Figura 75 - Questão 9

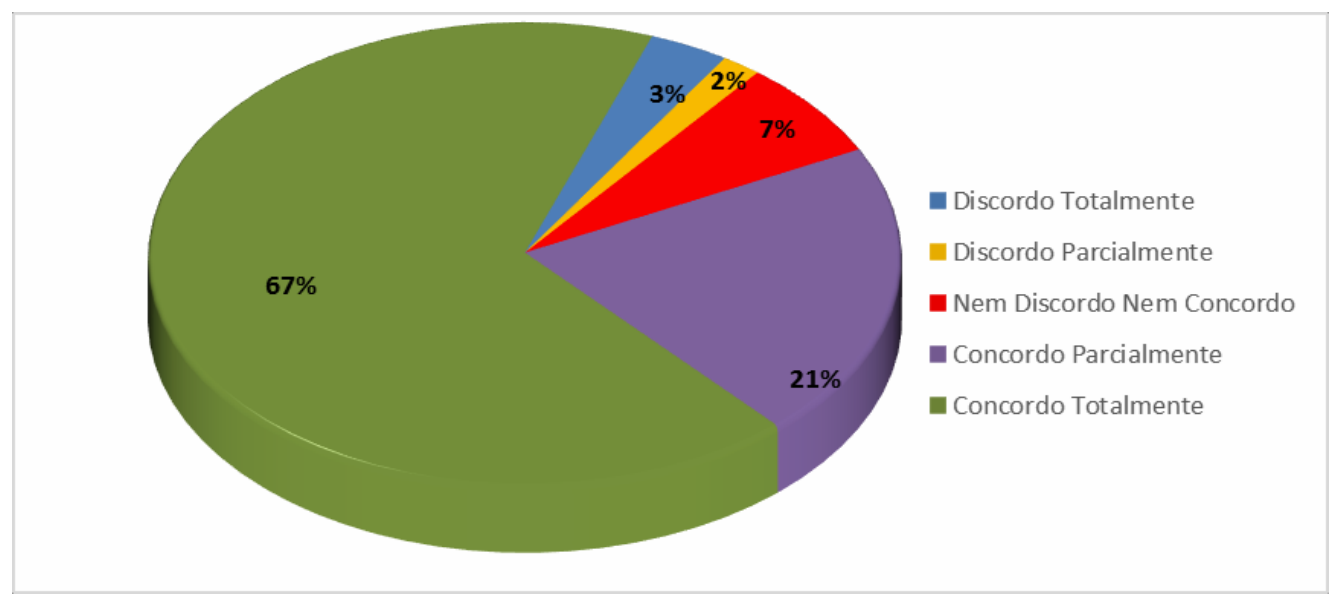

Fonte: Próprio Autor.

As questões 10 e 11 referem-se às disciplinas envolvidas no Projeto.

Figura 76- Interdisciplinaridade

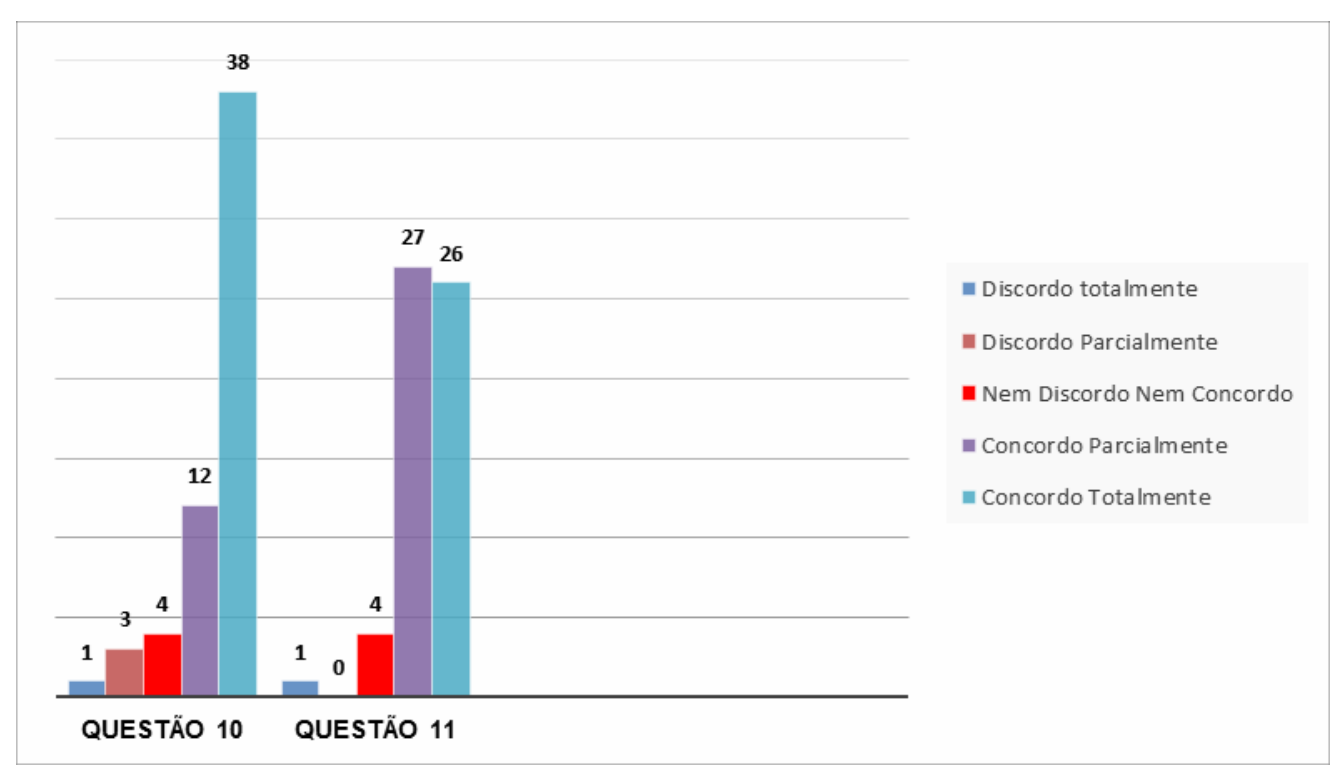

Fonte: Próprio Autor.

Na Questão 10: A utilização da ABP permitiu adquirir novos conhecimentos? Analisando os dados obtidos podemos observar que $65 \%$ dos alunos, afirmam ter aprendido com mais facilidade. Essa constatação vem confirmar que as aulas baseadas em metodologias ativas, são mais atraentes e despertam o interesse nos alunos. 
Figura 77 - Questão10

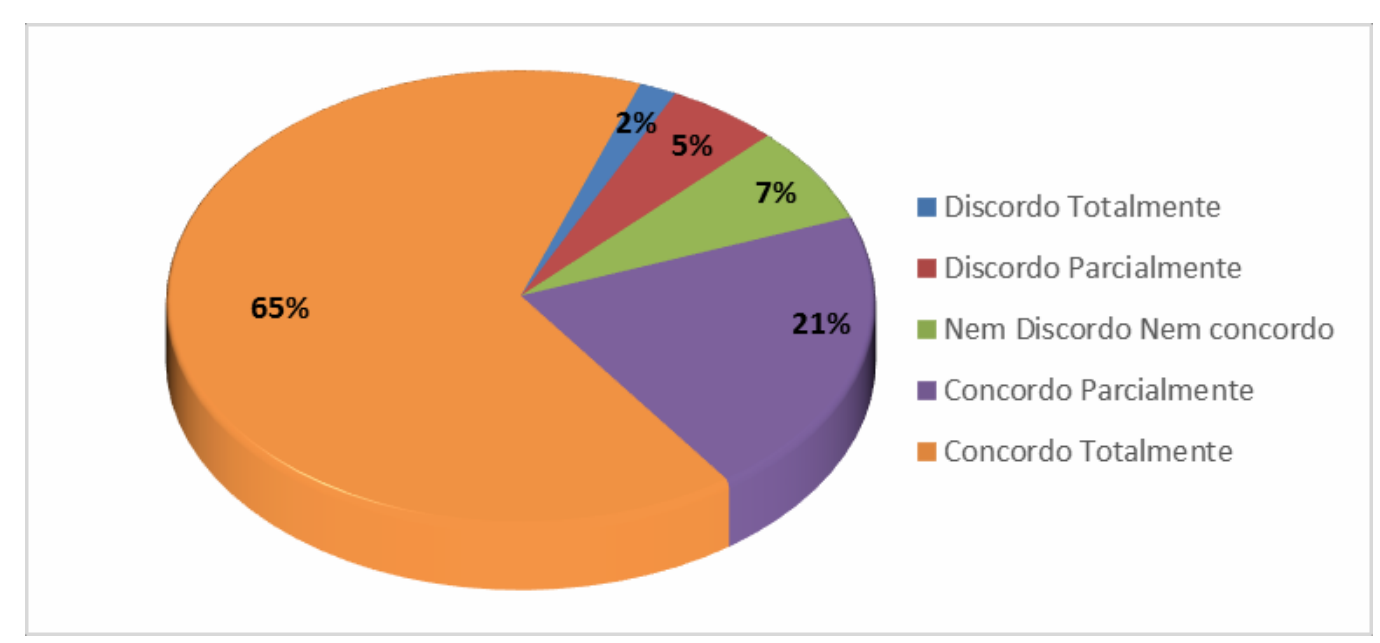

Fonte: Próprio Autor.

Na questão 11: a ABP permitiu relacionar questões ambientais e sustentabilidade?

Figura 78 - Questão 11

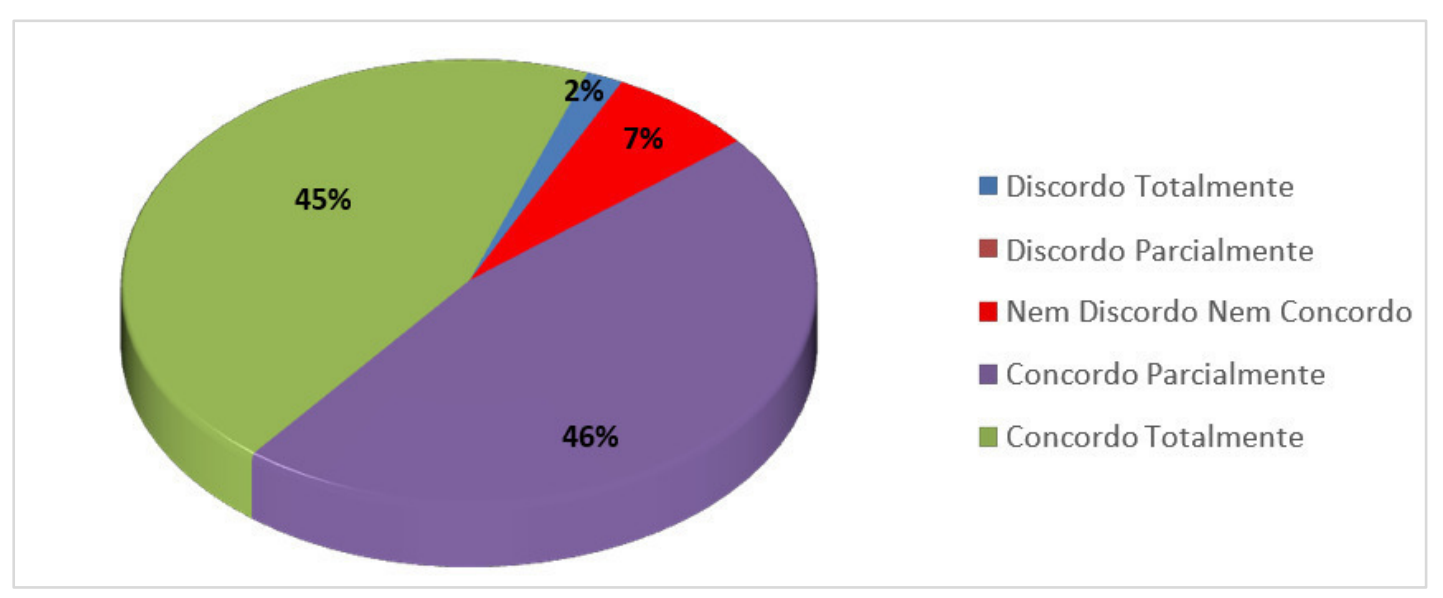

Fonte: Próprio Autor.

Na pesquisa ficou claro que os alunos gostaram de trabalhar o método aplicado a Educação Ambiental. Essa análise ratifica o que está escrito nos PCNs (1999) quando destaca o Tema Meio Ambiente, para ser trabalhado em todas as disciplinas como Tema Transversal. Nas Questões: 12, 13, 14 e 15, analisamos a aplicação do método (Figuras: 79 a 83). 
Figura 79 - A aplicação da ABP

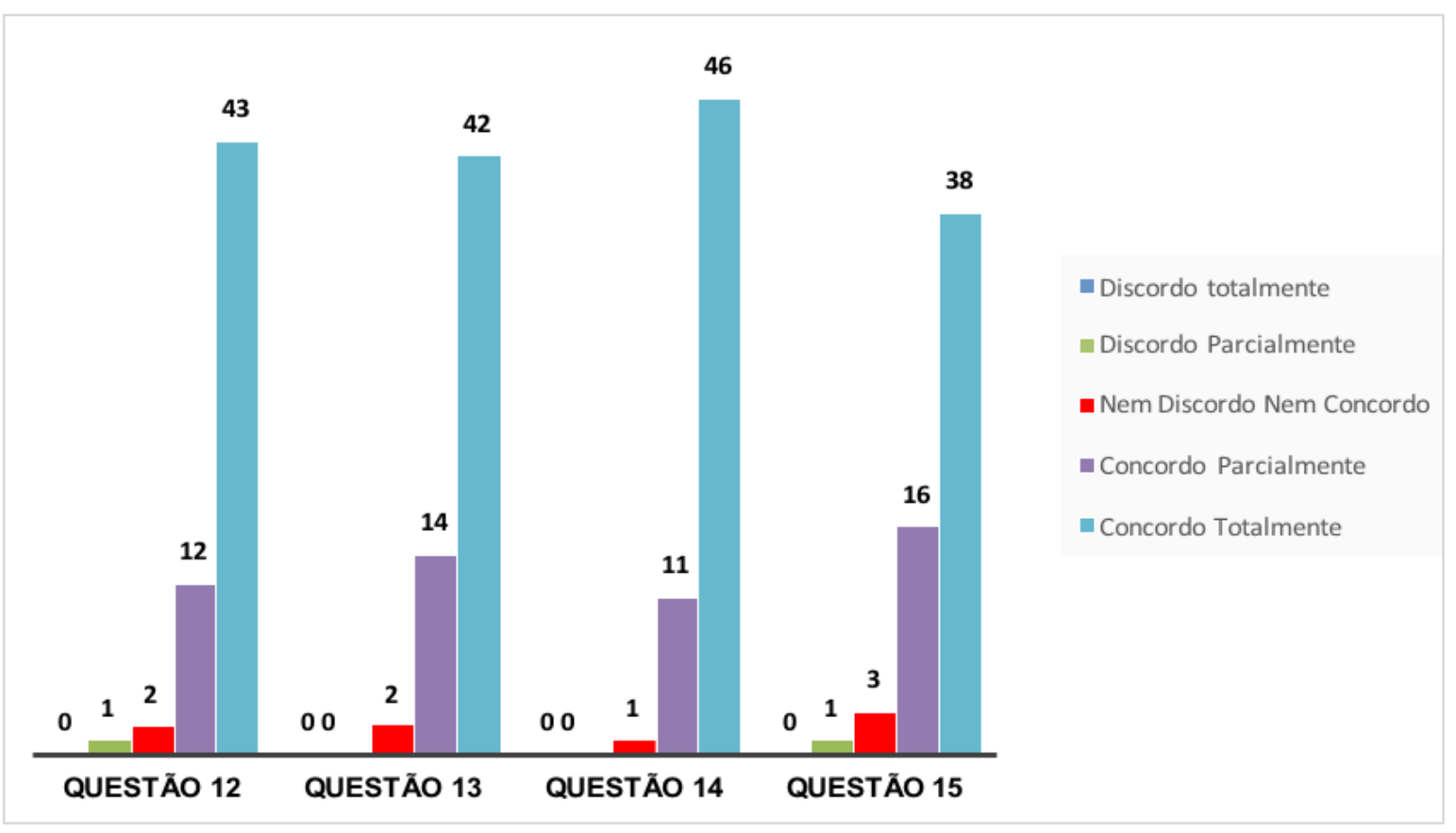

Fonte: Próprio Autor.

Questão 12- Os conceitos do método ABP devem ser aplicados em mais disciplinas? Pela aceitação dos alunos, 74\%, percebe-se que a utilização do método pelas outras disciplinas teria um resultado muito satisfatório. Observa-se ainda que por meio das respostas dos entrevistados houve maior interação dos conteúdos trabalhados em sala de aula com o método, favorecendo uma aprendizagem mais dinâmica e significativa.

Figura 80 - Questão 12

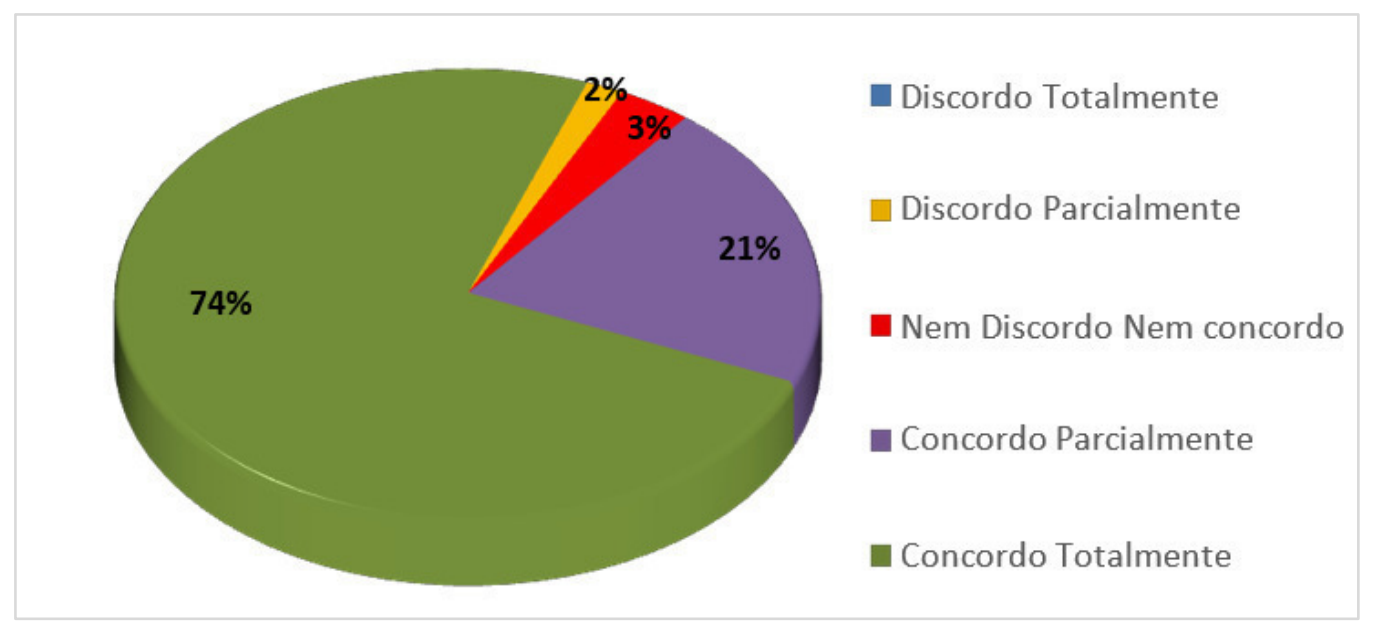

Fonte: Próprio Autor. 
Questão13: A metodologia ABP, aprimora as relações interpessoais? A análise da pesquisa mostra que $72 \%$ responderam que sim, que com o método são capazes de trabalharem em grupo, respeitando a opinião um dos outros e ajudando aqueles que encontraram mais dificuldades.

Figura 81- Questão 13

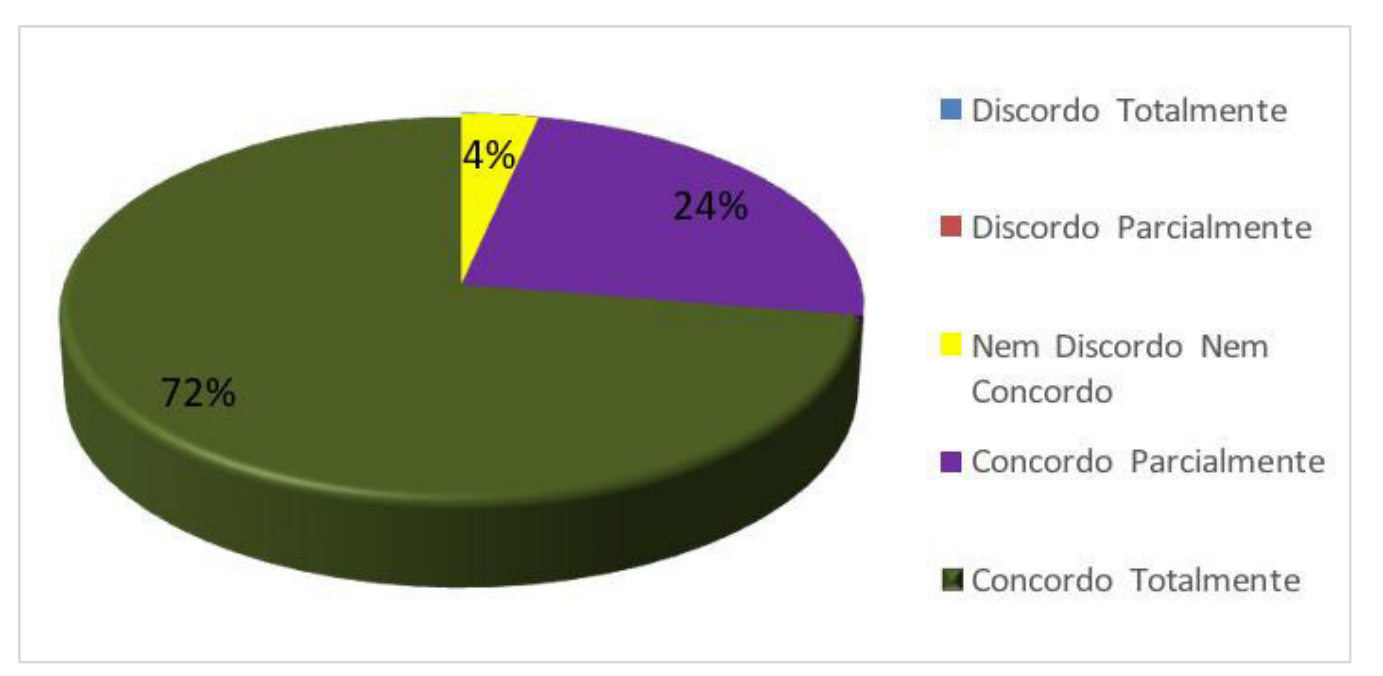

Fonte: Próprio Autor.

Questão 14 - O trabalho com ABP possibilitou o envolvimento das disciplinas das áreas de conhecimento, a saber: Arte, Física, História, Língua Portuguesa, Geografia e Matemática? A pesquisa mostra que $79 \%$ dos alunos afirmam que é possível a integração dos conteúdos e o sucesso do trabalho ocorre porque o envolvimento das disciplinas é essencial para que o aluno olhe de maneiras diferentes para a mesma situação.

Figura 82 - Questão 14

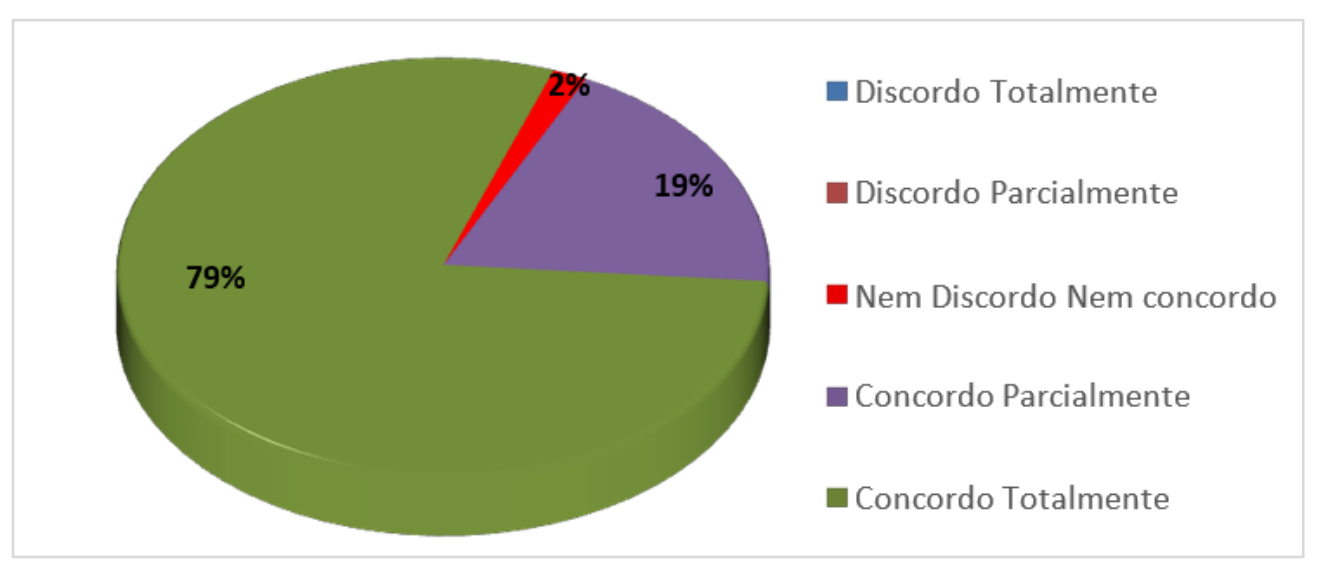

Fonte: Próprio Autor 
Questão 15 - Verifica-se uma relação entre a utilização de tecnologias e o trabalho desenvolvido no projeto? Nota-se que $65 \%$ dos resultados apontam que é muito importante utilizar a tecnologia em ambiente escolar, pois além de reduzir o tempo de estudo, permite que as aulas se tornem mais dinâmicas e participativas.

Figura 83 - Questão 15

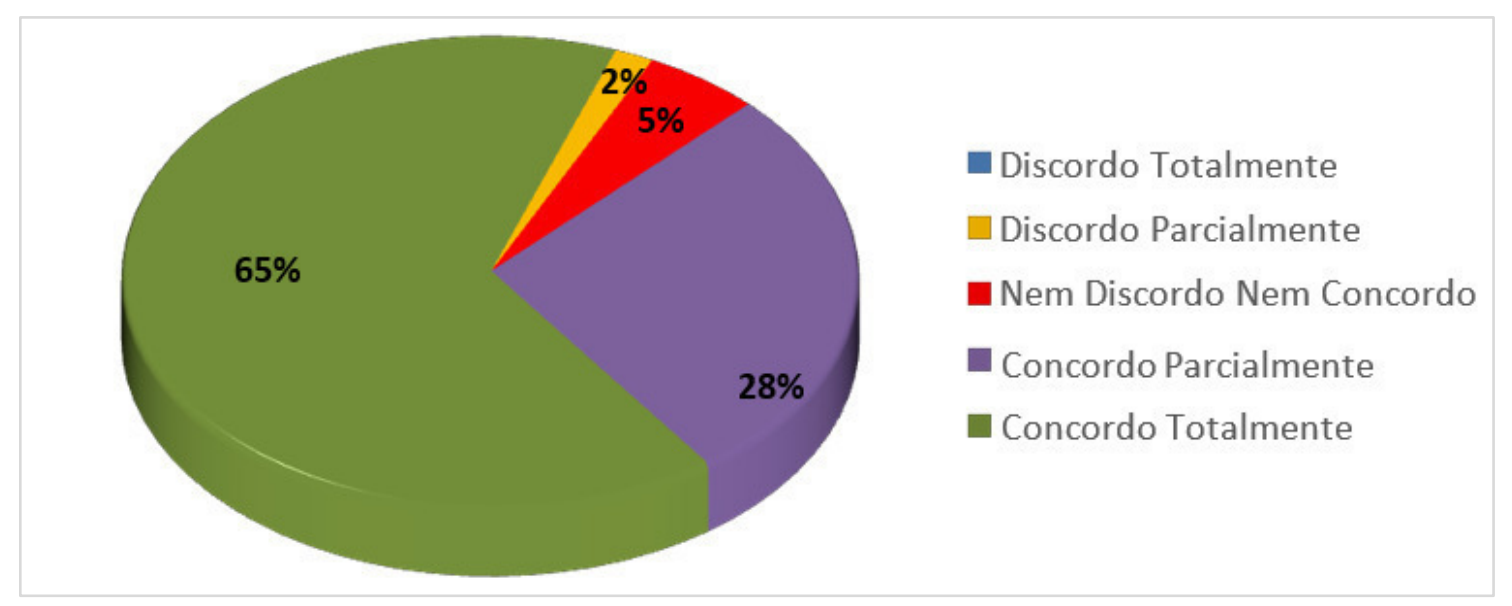

Fonte: Próprio Autor.

É importante destacar que a disciplina de Língua Portuguesa foi aplicada, em todas as etapas do Projeto por meio de leitura, interpretação e construção de textos, sendo essa uma das preocupações constante do ensino, segundo demonstra a literatura. Outra contribuição dessa disciplina foi a construção do Blog. 


\section{CONSIDERAÇÕES FINAIS}

Esta pesquisa propôs investigar as possíveis contribuições do método Aprendizagem Baseada em Projetos (ABP), que coloca o aluno como sujeito ativo, crítico e reflexivo na aquisição do conhecimento. A revisão da literatura tem demonstrado uma eficácia por meio da aplicação das metodologias ativas no processo ensino e aprendizagem. Percebe-se por meio de pesquisas de autores nacionais e internacionais que trabalhar com recursos naturais não é algo novo, principalmente quando se trata de vincular a um projeto de engenharia, como no caso da criação de uma cisterna para captação de águas pluviais para fins não potáveis. Raramente encontramos a aplicação da ABP, nos dois níveis de ensino: médio e fundamental.

A aplicação da Aprendizagem Baseada em Projetos requer do educador a escolha de um problema que seja motivador, um tópico do mundo real que exija uma investigação profunda e que seja relevante pra os estudantes. É importante ressaltar que o projeto envolveu uma natureza mais ampla, permitindo ao educando articular o conhecimento nas disciplinas de História, Geografia, Matemática, Língua Portuguesa e Arte a desenvolver competências técnicas para resolução de problemas.

Esse método é uma ferramenta extraordinária para o professor, entretanto é preciso que o professor tutor domine todas as etapas do método, definindo novas estratégias para quando surgirem imprevistos durante o percurso de aplicação. Todas as estratégias foram preparadas para instigar o problema em questão e acompanhar o processo de desenvolvimento e das ações desencadeadas e, o apoio da gestão foi muito importante para efetivação do projeto.

Faz-se necessário também, tirar um tempo para refletir em grupo e individualmente, as notícias do projeto. É um momento dos professores compartilharem suas experiências, dúvidas, anseios, inseguranças e avaliarem os pontos de ajustes do projeto, isso é, o que não funcionou bem e precisa ser melhorado.

A partir da confirmação dos resultados, podemos afirmar que a pesquisa realizada apresentou resultados positivos em relação à aplicação do método na educação básica, contribuindo significativamente para o desenvolvimento de habilidades e competências técnicas exigidas na resolução de problemas.

Essa pesquisa, por meio dos resultados dos questionários desenvolvidos com os alunos, demonstrou uma integração dos dados obtidos pela pesquisa bibliográfica, sendo considerado um resultado positivo. As atividades em grupo, com experimentos foram 
eficazes, permitiu ao educando analisar, levantar hipóteses trabalhar em equipe, utilizar as TICs e questionar as questões ambientais. Esses resultados corroboram para aguçar o saber científico e desenvolver possíveis iniciativas no ensino, de forma a promover mudanças de práticas pedagógicas, melhorando o rendimento dos alunos.

A pesquisa permitiu romper com o paradigma das aulas tradicionais reduzindo a distância entre teoria e a prática. Como esse método não é um modelo fixo e nem fechado, a Aprendizagem Baseada em Projetos pode ser adaptada às diversas realidades da educação básica. Espera-se que essa pesquisa seja de grande contribuição para os colegas professores.

Apesar do êxito obtido, pretendemos em um trabalho futuro analisar a postura do professor em relação ao método. É relevante recomendar que outros temas ambientais sejam trabalhados com a aplicação da Aprendizagem Baseada em Projetos, como uma alternativa de aprendizagem, desenvolvendo no educando as habilidades e competências técnicas necessárias para o mundo atual. 


\section{REFERÊNCIAS}

ACADEMIA BRASILEIRA DE CIÊNCIAS. O Ensino de ciências e a educação básica: propostas para superar a crise. Rio de Janeiro: Academia Brasileira de Ciências, 2008.

ALMEIDA, M. E. B. Projeto: Uma nova cultura de aprendizagem. Porto: ed. Porto, 1999.

ANDRÉ M, LÜDKE M. CRUZ, G. B A produção do conhecimento didático e a formação de professores no Brasil. Currículo, didática e formação de professores. Campinas: Papirus. 2013.

ARAÚJO, A. S. Percurso da Educação Ambiental Dentro e Fora do Contexto Educacional. In: CONEDU,1., 2014, Campina Grande PB. Anais... v.1, n.1.

AUSIN, V.; et al. Project-Based Learning through ICT: An Experience of Teaching Innovation from University Classrooms. Revista Formación Universitaria, vol. 9, n.3, p.3138, 2016.

BARBOSA, E. F.; CONTIJO, A. F.; SANTOS, F. F. Inovações pedagógicas em educação profissional: uma experiência de utilização do método de projetos na formação de competências. Boletim técnico do Senac, v. 30, n. 2, mai./ago. 2004.

BARROWS, H. S. A Taxonomy of Problem-Based learning Methods. Medical education, nov. 20, 1986.

BORTOTI, M. L.; SANTOS, C. G. L.; PEREIRA, M. A. C. Aprendizagem baseada em Projetos: estudo de Caso com Integrantes em Engenharia de Produção. In: CONGRESSO DE EDUCAÇÃO EM ENGENHARIA, 41., 2013.

BRASIL. Diretrizes Curriculares Nacionais Gerais para a educação profissional de nível tecnológico. Brasília: MEC, 2002.

BRASIL. Lei no 9.795, de 27 de abril de 1999. Dispõe sobre a educação ambiental, institui a Política Nacional de Educação Ambiental e dá outras providências. Brasília, Diário Oficial da União, n. 79, p. 41- 43, 1999.

BRASIL. Ministério da Educação e do Desporto. Secretaria de Educação Fundamental. Parâmetros Curriculares Nacionais: pluralidade cultural, orientação sexual. Secretaria de Educação Fundamental. Brasília: MEC/SEF, 1997.

BRASIL. Ministério da Educação. Secretaria de Educação Fundamental. Parâmetros Curriculares Nacionais: terceiro e quarto ciclos do ensino fundamental. Brasília: MEC/SEF, 1998.

BRITO N. C; MANATTA, V. L. B. Didática Especial. São Paulo: Brasil, 1994.

BROWN, R. W. Why is quality assurance so difficult? A review of issues in quality assurance over the last decade. International Medicine Journal, v. 32, p. 331-337, 2002. 
BRUNEL. C. H.; VIESCA. M. V. I. Aprendizaje en proyectos situados: la universidad fuera del aula. Reflexiones a partir e a experiência. Sinéctica, Tlaquepaque, n. 43, p. 0116, jul/dic. 2014.

BUNGE, M. Ciência e desenvolvimento. São Paulo: Universidade de São Paulo, 1980.

CARAMELLO, G. W.; KAWAMURA, M. R. D. Uma educação na perspectiva ambiental crítica, complexa e reflexiva. Revista Brasileira de Pesquisa em Educação em Ciências, v. 14, n. 2, 2014.

CARVALHO, F. C. A.; IVANOFF, G. B. Tecnologias que educam: Ensinar e aprender com as tecnologias de informação e comunicação. São Paulo: Pearson Prentice Hall, 2010 .

CAVAlCANTE, C. M. Concepções e Práticas Educativas Baseadas na Gestão do Trabalhocom Projetos. Perspectivas em Gestão e Conhecimento, v. 1, n. 2, p. 266-288, 01 December, 2011.

CHAO, C. Y; CHEN, Y. T.; CHUANG, K. Y. Exploring students learning attitude andachievement in flipped learning supported computer aided design curriculum: A study in high school engineering education. Computer Applications in Engineering Education, v. 23, p. 514-526, July, 2015.

CHISTOFFOLETTI, G. et al. Grau de satisfação discente frente à utilização de métodos ativos de aprendizagem em uma disciplina de Ética em saúde. Revista Eletrônica de Educação, v. 8, ago, 2014.

DElizOICOV D.; ANGOTTI, J. A. P. Metodologia do Ensino de Ciência. São Paulo: Cortez, 1990.

DIXON, A.; BUTLER, D.; FEWKES, A. Water saving potential of domestic water reuse systems using grey water and rainwater in combination. Water Scienc e Technology, v. 39, n. 5, p. 25-32, 1999.

DOCHY, F. S. et al. Effects of problem basedlearning: A meta-analysis. Learning and Instruction, v. 13, p. 533-568, 2003.

DOLMANS, D.; GIJBELS, D. Research on problem-based learning: future challenges. Medical Education, v. 47, p. 214-218, February 20, 2013.

DUARTE, A. L. A.; MONACO, C. F.; MANSO, M. E. G. A Aprendizagem baseada em Problemas no Ensino de Ciências Básicas: experiência no segundo semestre do curso de Medicina de um Centro Universitário. Revista O Mundo da Saúde, 2013.

DYM, C.; LITTLE, P. Introdução à Engenharia: Uma abordagem baseada em Projeto. 3. ed. Porto Alegre: Bookman, 2010.

ESPINDOLA, B.; JOSÉ, M. Ubiquitous computer at school. Case study on tablet deployment project in elementary school. Educación. v. 24, n. 47, p. 27- 48, 2015. 
ESTEBAN, M. T. (Org.). Avaliação: uma prática em busca de novos sentidos. 3. ed. Rio de Janeiro: DP\&A, 2001.

FAZENDA, I. C. A. Interdisciplinaridade: história, teoria e pesquisa. Campinas, São Paulo: Papirus, 1994.

FERRARI, A.T. Metodologia da pesquisa científica. São Paulo: McGraw-Hill, 1982.

FINOCCHIO JUNIOR, J. Project Model Canvas - Gerenciamento de Projetos Sem Burocracia. Rio de Janeiro: Elsevier, 2013.

FONSECA, V. M. DA; BRAGA, S. R.; CICILLINI, G. A. Educação Ambiental como possibilidade de Unificar Saberes. Revista Terra Livre. Presidente Prudente, v. 1, n. 28 p. 239-

256. jan-jun, 2007.

FOUREZ, G. Crise no ensino de ciências? Investigações em Ensino de Ciências. Porto Alegre, v. 8, n. 2, p. 109-123, 2003.

FRACALANZA, H.; AMARAL, I. A.; GOUVEIA, M. S. F. O ensino de ciências no primeiro grau. São Paulo: Atual, 1986.

FREIRE, P. Pedagogia da autonomia: saberes necessários à prática educativa. São Paulo: Paz e Terra, 2001. n. 18.

FREZATTI, F. et al. Análise do Desempenho de alunos na Perspectiva do CHA em Disciplina utilizando PBL: O que significa a síntese? Revista de Contabilidade e Organizações, v. 10, n. 26, 2016.

GIL, A. C. Como elaborar projetos de pesquisa. 4. ed. São Paulo: Atlas, 2008.

GRANZOTTI, R. B. G. et al. Situação - problema como disparador do Processo Ensinoaprendizagem em Metodologias Ativas de Ensino. Revista CEFAC, v. 17, n. 6, p. 20812087, dez, 2015.

HANNEY, R; SAVIN-BADEN, M. The problem of projects: understanding the theoretical underpinnings of project-led PBL. London Review of Education, v. 11, n. 1, p. 7-19, 2013.

HAWKINS, T. R. et al. Comparative Environmental Life Cycle Assessment of Conventional and Electric Vehicles. Journal of Industrial Ecology, v. 17, n.1, p. 53-64, February, 2013.

HERNANDES, F.; MONTSERRAT V. A organização do currículo por projetos de trabalho. Porto Alegre: Artes Médicas, 1998.

HOFFMANN, J. M. L. Avaliação mediadora: uma prática em construção da préescola à universidade. Porto Alegre: Mediação, 2009. 
HUNG, P. H. et al. A Problem-based Ubiquitous Learning Approach to Improving the Questioning Abilities of Elementary School Students. Journal of Educational Technology e Society, v. 17, n. 4, p. 316-334, October, 2014.

JERZEMBEKA, G.; MURPHYA, S. A narrative review of problem-based learning with school- aged children: implementation and outcomes. Educational Review, v. 65, n. 2, 2013.

KAUFAMANN, F. Metodologia das Ciências Sociais. Rio de Janeiro: Francisco Alves, 1997.

KIM, D.G.; LEE, J. A Study on improving information processing abilities based on PBL.E- Learning Systems. Environments and Approaches, p. 199-210, 2014.

KÔCHE, J. C. Fundamentos da Metodologia Científica, 14. ed. Petrópolis: Vozes, 1997.

KONG, Ling-Na et al. The effectiveness of problem-based learning on development of nursing students' critical thinking: A systematic review and meta-analysis. International Journal of Nursing Studies, v. 51, n. 3, p. 458-469, March, 2014.

LAKATOS, E. M. ; MARCONI, M. A. Metodologia do Trabalho Científico. 4. ed. São Paulo: Atlas, 2006.

LAKATOS, E. M. ; MARCONI, M. A. Metodologia Científica. São Paulo: Atlas, 2004.

LEE, D.; HUH, Y.; REIGELUTH, C. M. Collaboration, intragroup conflict, and social skills in project-based learning. Instrucional Science, v. 43, n. 5. p. 561-590, 2015.

LEON, L. B.; ONÓFRIO, F. Q. Aprendizagem Baseada em Problemas na Graduação. Médica - Uma Revisão da Literatura Atual. Revista Brasileira de Educação Médica, Rio de Janeiro, v. 39, n. 4, out - dez, 2015.

LeVey, J. S.; GREenhall, A. The Penguin Concise Columbia Encyclopedia. Middlesex: Penguin Books, 1987.

LONG, Ting; QIN, Danian. Challenges of Conducting Problem-Based Learning in a Large Class. Chinese Education \& Society, v. 47, n. 3, p. 106-110, May-June, 2014.

LUDKE, M.; ANDRÉ, M. Pesquisa em educação: Abordagens qualitativas. 5. ed. São Paulo: EPU, 1986.

LUDKE, M.; ANDRÉ M. Pesquisa em Educação: abordagens qualitativas. 2. ed. Rio de Janeiro: GEN, v. 1, p. 112, 2013.

LUNARDI. J ; FIGUEIRÓ. A. Problematizando a Água Virtual em Educação Ambiental: Conceito e Forma de Cálculo. Revista Geonorte, Edição Especial, v. 3, n. 4, p. 290-300, 2012. 
MARCHÃO, A. J. G; FITAS A. C. P. A avaliação da aprendizagem na educação préescolar. O portefólio da criança. Revista Iberoamericana de educación, n. 64, p. 27-41, 2014.

MARCONI, M. A; LAKATOS, E. M. Técnicas de pesquisa: planejamento e execução de pesquisas, amostragens e técnicas de pesquisas, elaboração e interpretação de dados. 3. ed. São Paulo: Atlas, 1996.

MARINHO, P.; FERNANDES, P.; LEITE, C. A avaliação da aprendizagem: da pluralidade de enunciações à dualidade de concepções. Acta Scientiarum. Education, v. 36, n. 1, p.151-162, 2014.

MASSON, T. J.; et al. Metodologia de ensino: aprendizagem baseada em projetos (PBL). In: CONGRESSO BRASILEIRO DE EDUCAÇÃO EM ENGENHARIA - COBENGE, 40., Belém, PA, Brasil. 2012: Anais...

MATSUYAMA, F.; BEZZON, G.; SANTOS, C. D. G. Aplicação dos desafios, segundo a filosofia PBL, potencializar os conhecimentos auferidos pelos alunos, na resolução de problemas. Revista de Engenharia e Tecnologia, v. 6, n. 1, 2014.

MELO B. C.; SANT’ANA, G. A prática da Metodologia Ativa: compreensão dos discentes enquanto autores do processo ensino-aprendizagem. Revista Ciências e Saúde, v. 23, 2012 .

MONNERAT, L. P. Uma abordagem para a melhoria do processo de ensinoaprendizagem em desenho técnico utilizando métodos e técnicas da computação. Dissertação (Mestrado em Ciência da Computação) - Universidade Federal de Viçosa,Viçosa, 2012.

MONTEIRO, M. A. A. et al. A influência do discurso do professor na motivação e na interação social em sala de aula. Ciências e Educação, v. 18, n. 4, p. 997-1010, 2012.

MONTEIRO, M. A. A. Interações dialógicas em aula de ciências nas séries iniciais: um estudo do discurso do professor e as argumentações construídas pelos alunos. 204f. 2002. Dissertação (Mestrado em Educação para a Ciência - Área de concentração: Ensino de Ciências) - Faculdade de Ciências da Universidade Estadual Paulista, Bauru, 2002.

MORENO, M. A.; REIS, M. J; CALEFI, P. S. Concepções de professores de Biologia Física e Química sobre aprendizagem baseada em Problemas. Revista Hipótese, nov. 2013 .

NANDA.B.; MANJUNATHA. S. Indian medical students' perspectives on problem-based learning experiences in the undergraduate curriculum: One size does not fit all. Journal of educational evaluation for health professions, v. 10, p. 11, 2013.

PEREIRA, M. A. C.; BORTOTI, M. L.; SANTOS, C. G. L. Aprendizagem baseada em Projetos: Estudo de caso com ingressantes em Engenharia de Produção. In: CONGRESSO BRASILEIRO DE EDUCAÇÃO EM ENGENHARIA, 41. Gramado, RS, 2013. 
PERRENOUD, P. Dez novas competências para ensinar. Porto Alegre: Artmed, 2000.

PREETI, B.; ASHISH. A.; SHRIRAM, G. Problem Based Learning (PBL) - An Effective Approach to Improve Learning Outcomes in Medical Teaching. Revista J. Clin. Diagn. v. 7, dez, 2013.

QUEIROZ, J. R. C. et. al. Aprendizagem por Projeto e Inovação Tecnológica: União por Competências. Revista da ABENO, v. 16, n. 2, 2016.

REIGOTA, M. O que é educação ambiental. Coleção primeiros passo. São Paulo: Brasiliense, 2001.

RIBEIRO, L. R. C.; ESCRIVÃO FILHO, E; MIZUKAMI, M. G. N. Uma experiência com a PBL no ensino de engenharia sob a ótica dos alunos. Revista de Ensino de Engenharia, v. 23, n. 1, p. 63-17, 2004.

RICHARTZ, T. Metodologia ativa: A importância da pesquisa na formação de professores.Revista da Universidade Vale do Rio Verde, v. 13, p. 296-304, 2015.

RITTER, C. E. T. et al. Oficina de Biodiesel: Uma Estratégia de Aprendizagem para Estudantes do Ensino Médio. Revista Amazônica de Ensino de Ciências, v. 9, n. 18, jan jun, 2013.

ROCHA, H. M.; LEMOS, M. Metodologias Ativas: Relato de Pesquisar em Andamento. In SIMPÓSIO PEDAGÓGICO E PESQUISA EM EDUCAÇÃO, 2014.

SALOMON, G. Transcending the qualitative-quantitative debate: The analytic and systemic approaches to educational research. Educational Researcher, v. 20, n. 6 , p. 10$18,1991$.

SANTOS, C. G. L.; PEREIRA, M. A. C. Estudo de caso em aprendizagem baseada em projetos: um catalisador para o desenvolvimento de competências transversais. In: INTERNACIONAL SYMPOSIUM ON PROJECT APPROACHES IN ENGINEERING EDUCATION, 2014.

SANTOS, O. O.; LIMA, M. G. S. O processo de ensino aprendizagem da disciplina de Matemática: possibilidades e limites no contexto escolar. In: SIMPÓSIO DE PRODUÇÃO CIENTÍFICA, 10., SEMINÁRIO DE INICIÇÃO CIENTÍFICA, 9., Universidade Federal do Piauí. 2010.

SÃO PAUlO (Estado). Secretaria da Educação. Caderno do Professor: Geografia: $1^{\text {a }}$ série, v. 2, Ciências Humanas e suas Tecnologias. São Paulo: SE, 2015.

SILVA, C. M. et al. A Revolução da Robótica utilizando lixo eletrônico no Ensino Básico: Formação Ampliada e menor Vulnerabilidade de Jovens à Violência nas escolas Públicas. Revista do Laboratório de Estudos da Violência e Segurança, v. 12, n. 17, UNESP, 2016.

SILVA, L.S. et al. Formação de Profissionais Críticos- reflexivos: o potencial das metodologias ativas de ensino aprendizagem e avaliação na aprendizagem significativa. Revista CIDUI, n. 22014. 
SILVA, L. H. A; ZANON, L. B. Experimentação no Ensino de Ciências. In: SCHNETZER, Roseli P.; ARAGÃO, R. M. R. (Orgs.) Ensino de Ciências: fundamentos e abordagens. Campinas: Gráfica, 2000. cap 6. p. 120-153.

TAN, L. T.; GOH, B.; YAP, N. W. Project-based learning: Engaging secondary school students in authentic environmental science research. AsianYouth J. Biol, v. 3, p. 1- 4, 2015 .

TOMAZ, Plínio. Aproveitamento de água de chuva. São Paulo: ed. Navegar, 2003.

TREVELIN, A. T. C.; PEREIA, M. A. A.; OllVEIRA, N. J. D. A utilização da sala de aula invertida em cursos superiores de tecnologia: comparação entre o modelo tradicional e o modelo invertido "flippedclassroom" adaptado aos estilos de aprendizagem. Revista Estilos de Aprendizaje, Madrid, v. 11, n. 12, 2013.

THIOLLENT, M. Metodologia da pesquisa-ação. 4. ed. São Paulo: Cortez, 1996.

VEGA, A.; BROWN. C. G. The Implementation of Project- Based Learning. National Forum of Educational Administration \& Supervision. Journal of Educational Administration, v. 30, p. 4-29, 2013.

VERGARA, S. C. Métodos de pesquisa em administração. 2. ed. São Paulo: Atlas, 2005. WANG, K. T. Research design in counseling. 4th ed. Nelson education, 2015.

WIEK, A. et al. Integrating problem-and project-based learning into sustainability programs: A case study on the School of Sustainability at Arizona State University. International Journal of Sustainability in Higher Education, v. 15, n. 4, p. 431-449, 2013.

WILDERA, S. Impact of problem-based learning on academic achievement in high school: a systematic review. Educational Review. v. 67, 2015.

WRIGH, D.; WICKHAM, J.; SACH, T. Problem-based learning: an exploration of student opinions on its educational role in one UK pharmacy undergraduate curriculum. International Journal of Pharmacy Practice, v. 22, n. 3, p. 223- 228, 2014.

YIN, R. K. Estudo de Caso: planejamento e métodos. Porto Alegre: Bookman, 2010.

YOUNG, T. P., e McLean, S. I. A critical look at lean thinking in healthcare. Quality e Safety in Health Care, v. 17, p. $382-386,2008$. 


\title{
APÊNDICES
}

\section{APÊNDICE A - Questionário sobre ABP e Competências Transversais}

\section{Questionário de Avaliacão: Projeto de Educacão Ambiental}

\author{
Objetivo: Avaliar a aplicação método ABP e Competências Transversais por meio da

\section{Educação Ambiental.}

Leia atentamente cada afirmação e responda aquilo que reflete a sua opinião.

\begin{tabular}{|c|c|c|c|c|c|c|}
\hline & & \begin{tabular}{|c|} 
Discordo \\
Totalmente
\end{tabular} & $\begin{array}{c}\text { Discordo } \\
\text { Parcialmente }\end{array}$ & $\begin{array}{c}\text { Nem } \\
\text { Discordo } \\
\text { Nem } \\
\text { Concordo }\end{array}$ & $\begin{array}{c}\text { Concordo } \\
\text { Parcialmente }\end{array}$ & $\begin{array}{c}\text { Concordo } \\
\text { Totalmente }\end{array}$ \\
\hline \multicolumn{7}{|c|}{ Competência de trabalho em equipe } \\
\hline & $\begin{array}{l}\text { Os membros do grupo têm contribuído para o } \\
\text { sucesso do trabalho. }\end{array}$ & & & & & \\
\hline 2 & $\begin{array}{l}\text { Os membros dos grupos têm participado de todas } \\
\text { as reuniões. }\end{array}$ & & & & & \\
\hline 3 & $\begin{array}{l}\text { Os conflitos vivenciados pelo grupo têm sido } \\
\text { superados de maneira coerente e respeitosa. }\end{array}$ & & & & & \\
\hline \multicolumn{7}{|c|}{ Competência de desenvolvimento pessoal } \\
\hline & $\begin{array}{l}\text { O projeto ajuda a desenvolver a criatividade para a } \\
\text { resolução de problemas. }\end{array}$ & & & & & \\
\hline 5 & $\begin{array}{l}\text { O projeto possibilitou o desenvolvimento do senso } \\
\text { crítico, presente nas diferentes propostas de } \\
\text { trabalho. }\end{array}$ & & & & & \\
\hline \multicolumn{7}{|c|}{ Competência de comunicação } \\
\hline 6 & $\begin{array}{l}\text { A comunicação do grupo através do protocolo de } \\
\text { comunicação tem sido eficaz. }\end{array}$ & & & & & \\
\hline 7 & $\begin{array}{l}\text { A capacidade de comunicação escrita e oral tem } \\
\text { sido, desafiada nesse projeto. }\end{array}$ & & & & & \\
\hline \multicolumn{7}{|c|}{ Competência de gestão de projeto } \\
\hline 8 & $\begin{array}{l}\text { As reuniões foram produtivas e decisivas para a } \\
\text { continuidade do projeto. }\end{array}$ & & & & & \\
\hline 9 & $\begin{array}{l}\text { O grupo tem cumprido todos os prazos } \\
\text { estabelecidos. }\end{array}$ & & & & & \\
\hline \multicolumn{7}{|c|}{ Interdisciplinaridade } \\
\hline 10 & $\begin{array}{l}\text { A utilização da ABP permitiu adquirir novos } \\
\text { conhecimentos. }\end{array}$ & & & & & \\
\hline 11 & $\begin{array}{l}\text { A ABP permitiu relacionar questões ambientais e } \\
\text { sustentabilidade. }\end{array}$ & & & & & \\
\hline \multicolumn{7}{|c|}{ Avaliação da metodologia } \\
\hline & $\begin{array}{l}\text { Os conceitos de ABP deveriam ser utilizados em } \\
\text { mais disciplinas. }\end{array}$ & & & & & \\
\hline 13 & $\begin{array}{l}\text { A metodologia ABP aprimora o desenvolvimento } \\
\text { das relações interpessoais. }\end{array}$ & & & & & \\
\hline & $\begin{array}{l}\text { O trabalho com ABP possibilitou o envolvimento } \\
\text { das disciplinas das áreas de conhecimento, a saber: } \\
\text { Arte, Física, Geografia, História, Língua } \\
\text { Portuguesa e Matemática. }\end{array}$ & & & & & \\
\hline 15 & $\begin{array}{l}\text { Verifica-se uma relação entre a utilização de } \\
\text { tecnologias e o trabalho desenvolvido no projeto. }\end{array}$ & & & & & \\
\hline
\end{tabular}

Escreva no verso tudo que julgar relevante para o aprimoramento do nosso trabalho usando $A B P$. 


\section{APÊNDICE B - Questionário sobre ABP e o Projeto}

\section{$\underline{\text { Avaliacão Dissertativa }}$}

Objetivo: Avaliar a aprendizagem dos alunos envolvidos na pesquisa em relação ao método e a interdisciplinaridade.

1- Qual a sua opinião em relação à Metodologia Ativa de ensino (ABP)?

2- Qual relação você encontrou no projeto com a Física?

3- Qual relação você encontrou no projeto com a Geografia?

4- Qual relação você encontrou no projeto com a Matemática?

5- Qual relação você encontrou no projeto com a Arte?

6- Você gostou do método ABP aplicado à Educação ambiental?

7- Quais melhorias sugerem para o andamento do projeto?

8- Deixe sua crítica ou sugestão em relação ao método de Aprendizagem por Projetos.

Obrigada pela sua participação! 